Csilla E. Ariese and Magdalena Wróblewska

\title{
Practicing Decoloniality in Museums
}

\section{A Guide with Global Examples}

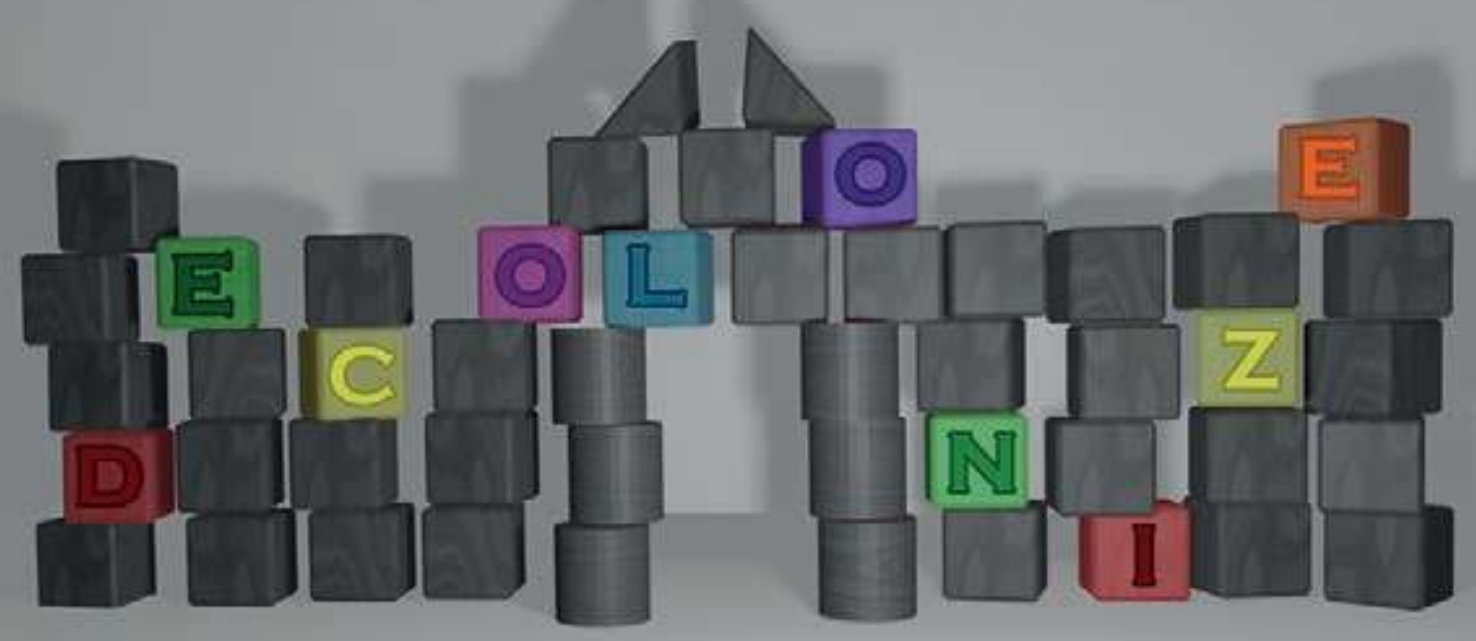


Practicing Decoloniality in Museums 



\title{
Practicing Decoloniality in Museums
}

\author{
A Guide with Global Examples
}

Csilla E. Ariese and Magdalena Wróblewska 
Cover illustration: To decolonize the museum is to replace every block Image by Csilla E. Ariese and Bram van den Hout, 2021

Cover design: Coördesign, Leiden

Typesetting: Crius Group, Hulshout

$\begin{array}{ll}\text { ISBN } & 9789463726962 \\ \text { e-ISBN } & 9789048554836 \text { (pdf) } \\ \text { DOI } & 10.5117 / 9789463726962 \\ \text { NUR } & 657\end{array}$

\section{(c) $(1) \Theta$}

Creative Commons License CC BY NC ND (http://creativecommons.org/licenses/by-nc-nd/3.o)

$\circledast$ All authors / Amsterdam University Press B.V., Amsterdam 2022

Some rights reserved. Without limiting the rights under copyright reserved above, any part of this book may be reproduced, stored in or introduced into a retrieval system, or transmitted, in any form or by any means (electronic, mechanical, photocopying, recording or otherwise). 
The legacies of European colonialism are immeasurably deep, farreaching and ever-mutating, and so decolonial work and resistance must take on different forms, methods and evolve accordingly.

- Sumaya Kassim, The Museum Will Not Be Decolonised 



\section{Table of Contents}

Introduction $\quad 11$

$\begin{array}{ll}\text { What is the problem? } & 11\end{array}$

$\begin{array}{ll}\text { What is in this book? } & 14\end{array}$

$\begin{array}{ll}\text { For whom is this book? } & 16\end{array}$

$\begin{array}{ll}\text { How to design your own decolonial practice } & 18\end{array}$

1 Creating Visibility 21

The challenge $\quad 21$

The change $\quad 23$

International Slavery Museum (UK) $\quad 24$

$\begin{array}{ll}\text { Tropenmuseum (NL) } & 26\end{array}$

Mutare Museum (ZW) $\quad 28$

Belmont Estate (GD) $\quad 29$

Further reading $\quad 32$

Further examples $\quad 32$

2 Increasing Inclusivity $\quad 37$

$\begin{array}{ll}\text { The challenge } & 37\end{array}$

$\begin{array}{ll}\text { The change } & 39\end{array}$

Corona in the City $\mid$ Amsterdam Museum (NL) 40

GLOW | Santa Cruz Museum of Art \& History (US) 42

Museum of London (UK) 44

Liberty Hall: The Legacy of Marcus Garvey (JM) $\quad 46$

$\begin{array}{lr}\text { Further reading } & 48\end{array}$

$\begin{array}{lr}\text { Further examples } & 49\end{array}$

3 Decentering $\quad 51$

The challenge $\quad 5^{1}$

The change $\quad 52$

Memento Park (HU) 54

Dress Code: Are You Playing Fashion?| National Museum of

Modern Art (JP) $\quad 5^{6}$

Spitzmaus Mummy in a Coffin and Other Treasures | Kunsthistorisches Museum (AT) $\quad 5^{8}$

Indigenous 'Museum-like' Centers (CA \& US) 60

Further reading $\quad 62$

$\begin{array}{ll}\text { Further examples } & 62\end{array}$ 
4 Championing Empathy $\quad 67$

$\begin{array}{ll}\text { The challenge } & 67\end{array}$

$\begin{array}{ll}\text { The change } & 69\end{array}$

National Museum of African American History and Culture (US) 70

$\begin{array}{ll}\text { Museo Tula }(\mathrm{CW}) & 72\end{array}$

POLIN Museum of the History of Polish Jews (PL) 74

$\begin{array}{ll}\text { Tate Modern (UK) } & 76\end{array}$

$\begin{array}{ll}\text { Further reading } & 78\end{array}$

$\begin{array}{ll}\text { Further examples } & 78\end{array}$

5 Improving Transparency $\quad 81$

$\begin{array}{ll}\text { The challenge } & 81\end{array}$

$\begin{array}{ll}\text { The change } & 83\end{array}$

International Inventories Program | National Museum Nairobi

\& Goethe-Institut Kenya (KY) 84

The Past Is Now | Birmingham Museum \& Art Gallery (UK) 86

Museum of British Colonialism (KY \& UK) 88

Musée des Civilisations Noires (SN) 90

$\begin{array}{lr}\text { Further reading } & 92\end{array}$

$\begin{array}{ll}\text { Further examples } & 93\end{array}$

6 Embracing Vulnerability $\quad 97$

$\begin{array}{ll}\text { The challenge } & 97\end{array}$

$\begin{array}{lr}\text { The change } & 99\end{array}$

The Museum of Others | Pitt Rivers Museum (UK) 100

Scaffold | Walker Art Center (US) 102

Muzeum krytyczne (Critical Museum) by Piotr Piotrowski (PL) 104

Voices from the Colonies | National Museum of Denmark (DK) 106

$\begin{array}{ll}\text { Further reading } & 108\end{array}$

$\begin{array}{ll}\text { Further examples } & 109\end{array}$

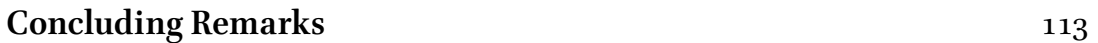

$\begin{array}{lr}\text { Contributors } & 114\end{array}$

$\begin{array}{ll}\text { Acknowledgements } & 115\end{array}$

$\begin{array}{ll}\text { Author Biographies } & 116\end{array}$

$\begin{array}{ll}\text { References } & 117\end{array}$ 


\section{List of Illustrations}

Figure 0.1 A decolonial museology word cloud (the list of terms is suggestive rather than exhaustive) Image by Erica Lehrer, Decolonizing Museum Cultures and Collections: Mapping Theory and Practice in

East-Central Europe, keynote address, 21 October 2020

Figure 0.2 Infographic How to design your own decolonial practice Image by Anna Piwowar, 2021

Figure 1.1 Label text: "How Did the Museum Acquire Its Collections?" Tropenmuseum; photo by Csilla E. Ariese, 2019

Figure 1.2 The focus is on caring for the plantation estate's landscape rather than preserving its colonial mill Belmont Estate; photo by Csilla E. Ariese, 2014

Figure 2.1 Selected photographs from Black Lives Matter Amsterdam were also exhibited offline in the free-to-visit courtyard of the Amsterdam Museum Photo by Amsterdam Museum, Monique Vermeulen, 2020

Figure 2.2 GLOW: A Festival of Fire \& Light Photo by the Santa Cruz Museum of Art \& History (MAH), 2014

Figure 2.3 We are going on a mammoth hunt

Museum of London; illustration by Joshim; photo by Csilla E. Ariese, 2019

Figure 2.4 Garvey, Family and Community, mosaic mural created by students during the 2005, 2006, 2008, and 2010 Summer Art Programmes Liberty Hall courtyard; photo by Csilla E. Ariese, 2014

Figure 3.1 The decentered giant charging sailor, Republic of

Councils Monument

Memento Park; sculpture by István Kiss, 1969; photo

by Csilla E. Ariese, 2019

Figure 3.2 Juxtaposing costumes and contemporary art to question whether fashion requires cultural literacy.

Dress Code: Are You Playing Fashion?

National Museum of Modern Art, Kyoto; photo by

Csilla E. Ariese, 2019 
Figure 3.3 A vitrine organized by color had conservators reconsider how to display objects together that require different climates Kunsthistorisches Museum; photo by Csilla E. Ariese, 2019

Figure 4.1 Contemplative Court

National Museum of African American History and Culture; photo by Jason Flakes

Figure 4.2 The display on Afro-Caribbean literature includes a Papiamentu poem by Pierre Lauffer, beginning with the lines "Papiamentu indominable / Lenga di mi mama" Museo Tula; photo by Csilla E. Ariese, 2014

Figure 4.3 Decolonize language

Artwork by Elwing Sương Gonzalez aka

@elwingbling, 14 July 2020

Figure 4.4 Start introductory panel

Tate Modern; photo by Csilla E. Ariese, 2019

Figure 5.1 Screenshot of the home page of the International Inventories Program, 2021

Figure 5.2 Installation view of The Past Is Now exhibition Birmingham Museum and Art Gallery, 2017; photo (C) Birmingham Museums Trust

Figure 5.3 Screenshot of the webpage for the exhibition Emergency Museum of British Colonialism, 2021

Figure 6.1 Othering the Ethnologist, Augustus Pitt Rivers Christian Thompson, 2016; courtesy of the artist and the Yavuz Gallery

Figure 6.2 Removal of Sam Durant's Scaffold following mediation and a joint decision Walker Art Center; photo @ Walker Art Center, 2017

Figure 6.3 Ars Homo Erotica exhibition National Museum in Warsaw; photo by Raman Tratsiuk, 2010 


\title{
Introduction
}

\begin{abstract}
Practicing decoloniality in the museum is the myriad of approaches through which the current hooks of colonialism are being untangled from the museum institution. This chapter provides both an introduction to and an overview of the rest of this book, which is based on a conceptual framework of six aims of decolonization. This framework is coupled with practical examples from the field and around the globe. In this chapter we discuss the process of writing this book, the creation of the framework, the selection of examples, and the audience for whom this book is written.
\end{abstract}

Keywords: museums, decolonization, practicing decoloniality, global, practical examples

\section{What is the problem?}

Colonialism was not just a historical policy concerning the domination of other territories and their peoples. It included racial and racist ideologies to 'legitimize' such domination, the suppression of aspects of identity such as language and traditions, and the propaganda of a Western system of knowledge. Nations, organizations, companies, and individual actors were all involved in differing ways in the broad system of colonialism. It is thus a multi-tentacled entity that continues to influence and affect many aspects of the world today. In the words of Elizabeth Edwards, "the colonial is not merely a question of continuity or rupture, of influence or appropriation, but a presence that is all-saturating, overflowing, ever-present, persistent and fundamental to the experience of contemporary life." It is also thoroughly entangled with the institution of the museum. Colonial exploitations of living beings and resources, theories of racial evolution, notions of civilizing and educating lower classes - all of these and more are cemented into

$1 \quad$ Edwards 2018.

Ariese, Csilla E., and Magdalena Wróblewska, Practicing Decoloniality in Museums: A Guide with Global Examples. Amsterdam, Amsterdam University Press 2022 DOI: $10.5117 / 9789463726962 \_$INTRO 
the very foundation of the museum institution. Not only is the concept of the modern museum institution a colonial inheritance, but indeed, many collections, some museum buildings, and even older exhibitions are direct remnants from the colonial era. Colonial perspectives can also be read in today's systems of cataloguing and categorizing.

Since the colonial roots of the museum are so deep and wide-spread, decolonization is not just a matter for 'colonial museums' in the narrowest sense. Colonialism is a societal problem, not merely a problem for museums. As a result, whereas overt coloniality may be restricted to a portion of all the world's museums, decolonizing is relevant to all museums, even brand-new institutions. Decolonizing the museum has regularly been synonymized with the restitution of objects. Though important, this is only one small area where the museum needs to be severed from its colonial ties. That is why we choose to speak of practicing decoloniality: a process and a mode of thought that goes deeper into untangling the present-day colonial hooks from the museum. Beyond object repatriation, this could entail changed narratives and word usage in exhibitions, different hiring policies, new educational programs, and above all an awareness of colonial inheritances and problems that are openly discussed and highlighted.

In museums, practicing decoloniality has taken many shapes and forms. Examples abound from all around the world. Some early cases of exhibition projects that took a decolonial approach, such as Magiciens de la Terre (Centre de Pompidou, France, 1989) and Fred Wilson's Mining the Museum (beginning with the Maryland Historical Society, USA, 1992), are still referenced or used as inspiration today. Theoretical works, such as the development of the ecomuseum concept in the $1970{ }^{2},{ }^{2}$ or James Clifford's application of the term 'the contact zone' to museum spaces ${ }^{3}$ were highly influential alongside the broad field of post-colonial theories. The establishment of institutions dedicated entirely to formerly under-explored communities and themes, like the National Museum of the American Indian (USA, 1989), the International Slavery Museum Liverpool (UK, 2007), and the National Museum of African American History \& Culture (USA, 2016) were landmark events that resonated globally. Internationally, movements and organizations including MuseumDetox, MuseumHue, Decolonize the Museum, and \#MuseumsAreNotNeutral have gained visibility and from their external positions managed to affect specific changes, including the hiring or firing of museum staff in leadership positions. Museums have seen their spaces 
Figure 0.1 A decolonial museology word cloud (the list of terms is suggestive rather than exhaustive)

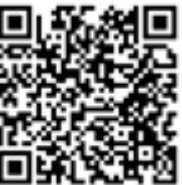

Image by Erica Lehrer, Decolonizing Museum Cultures and Collections: Mapping Theory and Practice in East-Central Europe, keynote address, 21 October 2020

used by external voices for alternative guided tours, such as Alice Procter's Uncomfortable Art Tours, the unique tours by MuseumHack, and the unadulterated audio guides created by Audio Tour Hack. The work-in-progress publication Words Matter ${ }^{4}$ provided a guide for language use. Though written mainly from the perspective of a Dutch ethnographic museum, it has global relevance and has influenced other museums to change the terminologies used in their exhibitions and collections.

As colonialism has left different marks on different communities and their institutions, decoloniality logically requires a unique approach in every case. Some of these decolonial practices have been evaluated, either by museums, by academics, ${ }^{5}$ or by (external) critics, to see if they have 'worked.' Again, the criteria for evaluation and success have been highly dependent on the specific setting and context of each case. Therefore, there is no way to evenly compare decolonial practices, nor is it fruitful to speak of 'best' practices - or 'worst' practices, for that matter. Therefore, this book is a collection of practices, but it does not aim to present evaluations of the examples included.

Instead, this book argues that practicing decoloniality, regardless of the scope or any 'results,' is crucially important for museums. The examples collected in this book aim to share practices from different contexts around the world. They are intended to serve as inspiration to anyone wishing to undertake their own decolonial approach. As the examples will show, practicing decoloniality is a complex issue and there is no one single solution that fits all. 


\section{What is in this book?}

There is no shortage of literature, whether academic or practical, that discusses and describes decolonial practices in museums. However, this literature often has a clearly demarcated focus on a specific type of practice. For instance, literature may focus on decolonizing art museums or ethnographic museums, centering firstly on the type of museum institution. Secondly, a common division is by area of the museum's work in which decolonization takes place, for example, exhibitions, educational programs, tours, staff policy, or collections. Finally, literature may home in on one specific kind of practice: artistic, curatorial, educational, scientific. In doing so, the practices tend to be relevant only for particular museum departments.

In this book, we have opted for a different approach. We have designed a conceptual frame with six aims of decolonization. This enables us to make a more thematic division in practicing decoloniality. The six aims are: creating visibility, increasing inclusivity, decentering, championing empathy, improving transparency, and embracing vulnerability. Of course, the ultimate aim of all of them is to untangle the present-day colonial hooks from the museum. These six aims are deliberately designed as rather broad conceptual terms that hinge on an active verb and therefore imply a required action. Our conceptual framework is decidedly not a typology. There are no strict criteria to determine which practice fits into which category. The benefit of this is that the framework allows for the inclusion of many different types of practices. As such, our book is of use to all types of museums, activities, and scales.

For this book, following the creation of our conceptual framework, we set out to gather examples of decolonial practices that we could include and share. We were not necessarily only interested in identifying 'best' practices. Rather, we set out to find examples that were diverse in terms of scale, target audiences, actors, and locations. It was important for us for the selection of examples in this book to reveal the specificity of local contexts while also charting the global dimensions of the movement towards decoloniality. Thus, some of the examples in the book are well-known, whereas others are perhaps almost unknown. We include them without evaluation to showcase the principle that all decolonial actions can be impactful, important, or inspirational and that depending on budget and scale practicing decoloniality is always possible in one way or another.

Curating the final selection of examples was difficult in two regards. Firstly, in practice, many examples can be related to more than just one aim of decolonization. Indeed, often the examples fit multiple aims. As 
colonialism is entangled with the museum institution on different levels, so too do decolonial practices target multiple such tentacles at once by combining more than one aim into a single practice. Thus, in describing the examples in the chapters, we focused our analysis and description mainly on the aim under which we had placed it, but it will be clear to the reader that other aims can also be identified. Secondly, there is such a wealth of examples to choose from that this became a challenge during the creation of this book. We tried to let diversity be our guide, choosing to represent different regions of the world and different museums, even if often the same institution could have been included with multiple projects. Throughout our selection process, we came across so many additional interesting and relevant examples that we chose to include in each chapter some 'further examples' with brief descriptions, but without analysis.

As mentioned, the book is divided into six chapters, each of which focuses thematically on one of our aims of decolonization. Firstly, we explore how to create visibility, for instance for histories or persons who have been previously marginalized. Secondly, we discuss increasing inclusivity, that is, how to - meaningfully! - include voices, actions, and perspectives of 'others' into the museum. Thirdly, we illustrate decentering, which is any act that aims to shift the norm. Fourthly, we describe ways in which museums can champion empathy among staff and visitors alike. Fifthly, we illuminate ways in which museums can improve transparency, for instance of their own contentious histories. Finally, we argue for the benefit of embracing vulnerability, of admitting what the museum and its staff lack, openly seeking out help, and accepting painful experiences. Each chapter begins with an essay in two parts, the first describing the particular challenges of decolonizing according to that one aim, followed up by the second, describing ways in which change can be approached. After the initial discussion, each chapter contains four practical examples from museums around the world.

It is key to recall that not all examples are directly about colonial exhibitions or objects. Afterall, as we mentioned above, decolonization is denormalization and decolonial practices are more broadly relevant and necessary than just for overtly colonial museums/exhibitions. Additionally, we need to emphasize that this book is not all-encompassing, nor evenly balanced in terms of geographical or cultural representation. We have chosen examples that show a wide range of ways of achieving specific aims, but at the same time we have been biased towards museums and their practices of which we have personal knowledge. Being able to describe these examples from our own perspective has been helpful, but of course also reveals our personal and professional biases. 
This book forms part of the research of the Horizon2020 project ECHOES, which focuses on the core dilemma that while the history of empires and colonialism undoubtedly constitutes a shared European past, this past remains strangely silent in official narratives about Europe's 'heritage.' Part of the ECHOES project has narrowed down its research to center on city museums, seeing cities as hubs where activists, artists, and city museums are at the forefront of re-emerging colonial heritages in the present. The interim results of our in-depth research of decolonial practices in two city museums, the Amsterdam Museum and the Museum of Warsaw, led us to conceptualize and develop this book. Both of us authors have worked as museum practitioners as well as in the academic field of museum studies. This perspective, a mixture of these two worlds, can be seen throughout the book.

\section{For whom is this book?}

This book is not a typical academic monograph on how museums are decolonizing. It is a conceptual framework to help museum staff, scholars, and students think about practicing decoloniality, coupled with practical examples from the field. This book is primarily for museum staff and cultural practitioners, secondarily for museum studies researchers and students, and naturally also for a generally interested audience of museum visitors and museum lovers.

We know that many museums are interested in practicing decoloniality and that staff at all levels and in all departments may be driven - or required - to engaged in decolonial practices. Of course, we also know that there are many museums where decoloniality has not (yet) been placed on the agenda. For those who wish to make a start, or continue practicing decoloniality, it can be daunting to identify the road forward, or find a how-to guide. A lot of literature is deeply academic and either based on single case studies or broadly theoretical. So, this book is for you. It couples brief, accessible essays with a wide selection of practical examples that are ready to serve as inspiration and guidance. You do not need to have any deep, academic knowledge of post-colonial theories to dive into this book, but it will provide entry points into decolonial thinking and suggestions for further readings to those interested. Most importantly, the examples in this book are selected in a way to hopefully always offer something that can be used or reused in your own institution.

For researchers and students in the field of museum studies, this book provides an entry point into the practical work going on within museum 
institutions. It is not a typical academic theoretical treatise, nor is it an analysis of decolonial literature. Instead, it delves into the practical dimension of decoloniality within museum settings. The many examples in this book showcase how diverse and different practicing decoloniality can be in reality. For students who have practical assignments as part of their courses, such as designing an audio tour or exhibition intervention, the examples will be particularly helpful. Additionally, the conceptual framework according to which we have divided the book into essays and examples is unique. Consisting of broadly grouped aims of decolonization, it is not a typology. Some of the six aims, such as championing empathy and embracing vulnerability, are not commonly spoken of within the field of decolonial practices. By using this conceptual framework, we have also been able to include examples that might otherwise not immediately be identified as 'decolonial,' perhaps because they do not concern overtly colonial collections or institutions.

For those readers who are museum visitors and museum lovers, we hope this book provides insight into practicing decoloniality. If you are part of a community surrounding a museum, the book can provide examples for greater involvement. Thus, it can give you more power to be involved in or influence the museums you care about. Having a greater awareness of the colonial entanglements of the museum and the problems of colonialism will change your visiting experiences and your perspective. You will notice new issues, gaps, or missing narratives. But you will also recognize those cases in which museums have made conscious changes. Practicing decoloniality in the museum is often a lengthy process of many small steps, which may go unnoticed to the wider public. But this book will showcase how all of these steps are crucially important to tearing away the colonial entanglements suffocating museum institutions.

To all of our readers, we hope you will be inspired by this book. For one, we believe the essays in each chapter are starting points to think about specific challenges and changes facing museums of the 21st century. The essays should inspire us to rethink the traditional, entrenched ways in which museums work and to discover ways in which that could be changed. What will the museum of the future be like - if there will even be museums in the future?

Additionally, we hope you will feel encouraged by the practical examples in each chapter. Some of them are easier to implement than others. They may work for only a certain type of museum or intended audience. But the hope is that there is something inspiring in here for any kind of museum that can lead to experimentation and alteration. Although the examples are listed under a single aim of decolonization, you will discover that each example may consist 
of a mix of different decolonial practices. Ultimately, since every museum institution is different, with vastly different staff and diverse (intended) audiences, you will need to mix your own recipe for practicing decoloniality.

\section{How to design your own decolonial practice}

Figure 0.2 Infographic How to design your own decolonial practice

Identify the problem:
find your own horizon of justice

Identify target audience.

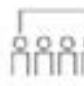

Determine the form of the practice:

- exhibition

- social media outreach

- educational program?

Find resources

(staff, fundings, material).
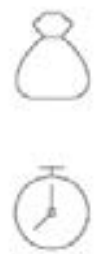

Schedule time for evaluation

during planning + during process + after.

Ensure there is room for adjustment based on evaluation (is there budget for changes?)

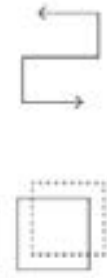

Determine aim:

what is the main point of action?

Ensure non-tokenistic involvement of target audience / stakeholders

Decide on scope and scale

- for how long?

\section{Transparently share}

lessons learned, do's and don'ts. 


\section{References}

Clifford, James. 1997. Routes: Travel and Translation in the Late Twentieth Century. Cambridge, MA: Harvard University Press.

de Varine, Hugues. 1978. "L'Écomusée." Gazette 11.2: 28-40.

Edwards, Elizabeth. 2018. "Addressing Colonial Narratives in Museums." The British Academy [blog], 19 April 2018. Available at https://www.thebritishacademy. ac.uk/blog/addressing-colonial-narratives-museums/ (accessed 1 April 2021).

Fouseki, Kalliopi, and Smith, Laurajane. 2013. "Community Consultation in the Museum: The 2007 Bicentenary of Britain's Abolition of the Slave Trade.” In Viv Golding and Wayne Modest, eds. Museums and Communities: Curators, Collections and Collaboration. London and New York: Bloomsbury. 232-245.

Modest, Wayne, and Lelijveld, Robin, eds. 2018. Words Matter: An Unfinished Guide to Word Choices in the Cultural Sector. Work in Progress series. Wormerveer: Tropenmuseum, Afrika Museum, Museum Volkenkunde and Wereldmuseum. 



\title{
$1 \quad$ Creating Visibility
}

\author{
Magdalena Wróblewska
}

\begin{abstract}
Historically, museums are successors of private collections and thus increasing visibility was a crucial part of establishing modern museum institutions. By providing access to collected objects, museums seemed egalitarian and democratic in their service. However, they represented a particular system of Western knowledge, even though presented objects were taken from all over the world. The gap grew between Western terms and categories on the one hand and things that were not inherently part of Western society on the other hand. This rendered objects and knowledge invisible that were not a product of this particular cultural and epistemic system.
\end{abstract}

Keywords: system of knowledge, exposition, visuality, realm of significance, repression

The decision to make things visible or invisible in museums is always related to power.

\section{The challenge}

Visibility has always been the main principle of the modern museum institution. In the 19th century, formerly private collections gained unprecedented visibility when transformed into public museums. New domains of visibility were created out of previously hidden areas and practices, that had once only been accessible to strictly limited, closed groups of people. Visibility in museums has always had its axiological dimension and has been associated with a wide range of values from the beginning of the museum institution. ${ }^{1}$ 
Krzysztof Pomian argues that all collections are involved in an exchange they establish between the visible and the invisible. ${ }^{2}$ What can be seen on display is viewed as valuable and meaningful because of the insight it offers into a sphere of significance that cannot itself be seen. The visible in the museum, rather than being significant for its own sake, gains value by affording a glimpse of a realm beyond itself: the order of nature, in the case of a natural history museum, or the order of history or art, in the case of cultural collections. Museums, through their methods of classifying and arranging artefacts, and the settings in which they are placed, serve a realm of significance that is invisible and absent (like past events), but at the same time they mediate visitors' access to that realm by making it metonymically visible and present.

However, such an interpretation raises the question: to whom are things in the museum visible? ${ }^{3}$ Pierre Bourdieu's social critique of modern art institutions as instruments of social distinction argued that only those with the appropriate cultural capital can see the objects in the museum as well as the realm of significance that is mediated by them. ${ }^{4}$ The entanglement of this hidden order in colonial structures of power was revealed by Gyan Prakash, who drew from Indian examples. ${ }^{5}$ Colonial museums in late 19th-century India were established more for Indian people than for British residents or European visitors. These institutions were created to reorganize local materials and indigenous objects in such a manner as to demonstrate the superior ordering Western science was able to provide. As such, these museums were used by the Indian elite to demonstrate their privileged access to European knowledge, thereby distinguishing themselves from the illiterate peasantry. These elites had trained themselves to see the realm of significance imposed on objects displayed in museums according to the principles of Western science.

The decision to make things visible or invisible in museums is always related to power, as it involves a particular system of knowledge. Historically, most museums were agents of the Western realm of significance and involved in the colonial regimes of European empires. However, nowadays these institutions are being decolonized through a process that implies a need to make changes to what is visible in their exhibitions. These changes affect both the objects displayed and topics addressed, effectively entailing 
changes of the underlying realm of significance. Sometimes this process brings about a deeper, structural change in the Western paradigm of the museum institution, being imposed as a sign of power or an educational tool. Increasing visibility in the museum used to be a privilege in the 19th century, but nowadays it tends instead to be perceived in moral categories, or as the responsibility every museum has to society. It is more about social justice and a voice being granted to those who were represented by others but had no means to present their own points of view. Simone Zeefuik, an activist from the Decolonize the Museum group, stated in 2016 that decolonizing is "to walk into your own family album without finding that all your pages are ripped out." ${ }^{\prime 6}$ The consequences of making things visible in a museum are hard to overestimate: it means making something public and disputable, and this can provoke moral reactions and even social change.

\section{The change}

Increasing visibility in the case of colonial pasts initially involves discovering or rediscovering certain parts of hidden, forgotten, or repressed - and thus untold - histories. The creation of a brand-new institution to serve as a platform for expressing a colonial past can be an effective way of approaching change, as is clear from the International Slavery Museum in Liverpool, the Musée des Civilisations Noires in Dakar, or the District Six Museum in Cape Town. But attempts to increase the visibility of (the problems of) colonialism usually assume more readily achievable forms, for example, a temporary exhibition, an intervention in an existing display, a commissioned artwork, or the publication of a book or catalogue. Increasing visibility is not only a question of displaying difficult heritages and histories. It is also a matter of showing them from a perspective other than the dominant. It may be asked whose point of view on colonial pasts is being presented or who is speaking about the heritage of the colonial era.

Such a change in viewpoint may bring about profound change in an old colonial institution, as was case with the permanent exhibition projects at the Tropenmuseum in Amsterdam or the Mutare Museum in Zimbabwe, both of which are discussed below. Traditional means of exhibiting, of displaying museum collections, have proved to be successful at facilitating the process of making hidden subjects visible. However, temporary exhibitions may be even more effective and radical in the presentation of challenging histories.

6 Post by @SYFUCollective quoting Simone Zeefuik, 16 April 2016; cited in Van Huis 2019: 228. 
This was certainly true in the case of the German Colonialism exhibition at the Deutsches Historisches Museum in Berlin in 2016, which was the institution's very first attempt to deal with the subject. Addressing the subject directly in this short-term project led the institution to revise and change part of permanent exhibition, namely its section about colonialism. It was opened on 1 July 2020, despite the Covid-19 pandemic and the fact that the permanent exhibition is soon to be closed for general renovations.

The challenge to colonial histories can also be made visible in museums' educational programs, ${ }^{7}$ irrespective of whether the exhibitions are critical and progressive. In some cases, guided tours and workshops with the public are perhaps more useful and effective media than the display of objects in space. One good example of such an approach is the Untold Histories Guided Tours offered to the public at the Museum of Archaeology and Anthropology (MAA) in Oxford. These tours, which promise to "tell what the labels won't," focus on displayed objects that were collected under colonial rule or during military conflicts in colonies. The tours were developed by three researchers of the University of Cambridge: Ananya Mishra, Danika Parikh, and Akshyeta Suryanarayan, with support of MAA curators. The project was inspired by an initiative by Alice Procter, who independently launched her Uncomfortable Art Tours. These present an uncompromised version of British colonial and imperial history at various London museums. On her website, which is called The Exhibitionist, she has published over 30 podcasts and shared an extensive bibliography for those who would like to learn more. She has also been active on social media (Facebook and Twitter), and her use of the internet for sharing knowledge and critically reflecting on museums' colonial entanglements is by no means exceptional. In fact, it reflects a new trend for communicating with museum audiences that has been used both by museums and their external critics, and has even enabled the establishment of alternative and independent museum institutions, like the Museum of British Colonisation.

\section{International Slavery Museum | Liverpool, UK}

The International Slavery Museum (ISM) in Liverpool opened on 23 August 2007, the date of the annual International Day for the Remembrance of the Slave Trade and its Abolition, which marks the beginning of the enslaved uprising in Saint Domingue (now Haiti) in 1791. It serves as a strong reminder that enslaved Africans were the main agents of their own 
liberation. The year 2007 was also significant as it was the bicentenary of the United Kingdom's Slave Trade Act of 1807, which abolished the trade in enslaved persons - though not slavery itself - inside the British Empire. It is not only the museum's date of opening, but also its location, that is meaningful. It is housed in Liverpool's Royal Albert Dock, at the center of a World Heritage Site, only meters away from the dry docks where the 18th-century slave trading ships were repaired and fitted out. The choice of location comments directly on the historical role played by Liverpool, which was regarded by the 1780 s as the European capital of the trans-Atlantic trade in enslaved persons, and benefited for much of the 19th century from cotton and other trade goods that were dependent on slave labor and the colonial system.

Before the ISM opened, the history of the trade in enslaved persons was presented as part of the city's maritime history at the Merseyside Maritime Museum, which is also located in the docks. Subsequently, a dedicated Transatlantic Slavery Gallery was created in 1994, which immediately gained worldwide recognition and attention and attracted a high volume of visitors. Although it was innovative for its time, it had become dated a dozen years after its opening and it was felt that the subject of slavery needed greater recognition and a different approach. This all led to the decision to establish a museum specially dedicated to the history of slavery that would be more capable of exposing and explaining slavery and its legacy. The new museum is now three times the size of the previous gallery and occupies a more prominent position on the third floor of the Merseyside Maritime Museum. The story of establishing a museum in its own right is the story of increasing the visibility of the subject of slavery.

The display space is split into three main galleries which focus, in turn, on the lives of historical people in West Africa (Life in West Africa), their following enslavement (Enslavement and the Middle Passage), and their continued fight for freedom (Legacy). New exhibitions incorporate the latest historical research, but these are not limited to the past and cover wider issues of the legacy of trans-Atlantic slavery and its contemporary relevance. The topics they cover include freedom and identity, social justice and human rights, underdevelopment in Africa and the Caribbean, racial discrimination and injustice, and the transformation of British and other cultures. The museum is increasing the visibility of these subjects using collections that are developed through partnerships with human rights organizations such as Stop the Traffik and Anti-Slavery International. The Contemporary Slavery collection highlights contemporary forms of slavery, such as bonded labor, early and forced marriage, forced labor, slavery by 
descent, human trafficking, and child labor. This collection is used as an interpretive tool to initiate discussions and dialogues about contemporary slavery, to support anti-slavery campaigns, and to raise awareness.

\section{Tropenmuseum | Amsterdam, the Netherlands}

The Tropenmuseum is an ethnographic museum located in Amsterdam. It forms the Nationaal Museum van Wereldculturen (National Museum of World Cultures) with two other ethnographic museums: the Museum Volkenkunde in Leiden and the Afrika Museum in Berg en Dal. The Tropenmuseum has been housed since 1926 in one of the most impressive museum buildings in the Netherlands. However, it was originally founded in 1864 and opened to the public in 1871 in Haarlem, as the Koloniaal Museum (Colonial Museum) by Frederick van Eeden, secretary of the Society for the Promotion of Industry. The institution's main goal was propagandistic, to present Dutch overseas possessions, such as Indonesia, and to convince people of the benefits being gained from the colonies and colonial trade. The museum also began research activities, mostly to increase any profits made off of the colonies.

Following the independence of Indonesia in $1945,{ }^{8}$ the museum's interests expanded beyond the Netherlands' colonial possessions to many other underdeveloped colonial states in South America, Africa, and Asia. Consequently, in 1949 it was renamed the Tropenmuseum. In the 1960 s and 1970s the Dutch Ministry of Foreign Affairs encouraged the museum to expand its scope to cover more social issues such as poverty and hunger and to develop its educational profile. In the early 1970 s a new wing for children was added, now called Tropenmuseum Junior. From the 199os, the idea emerged to change the Tropenmuseum's exhibitions and to present a different story of colonialism, including the role of the museum itself. A new permanent exhibition opened in 2003, titled Oostwaarts! (Eastward Bound!). This constituted one of the first attempts to expose the realm of colonialism, which had hardly ever been visually represented in museums anywhere in the world, let alone in the Netherlands. This aim was achieved by showing objects that were collected in Asia, mainly in Indonesia, as well as objects, images, and memories of the everyday life of colonizers.

Twelve years later, the exhibition became the subject of strong critiques by the Decolonize the Museum activist group and others who were using the hashtag \#DecolonizeTheMuseum on social media, posting about issues

8 Indonesia proclaimed its independence in 1945, and this claim was finally acknowledged by the Netherlands in 1949 after years of colonial warfare and violence. 
Figure 1.1 Label text: "How Did the Museum Acquire Its Collections?"

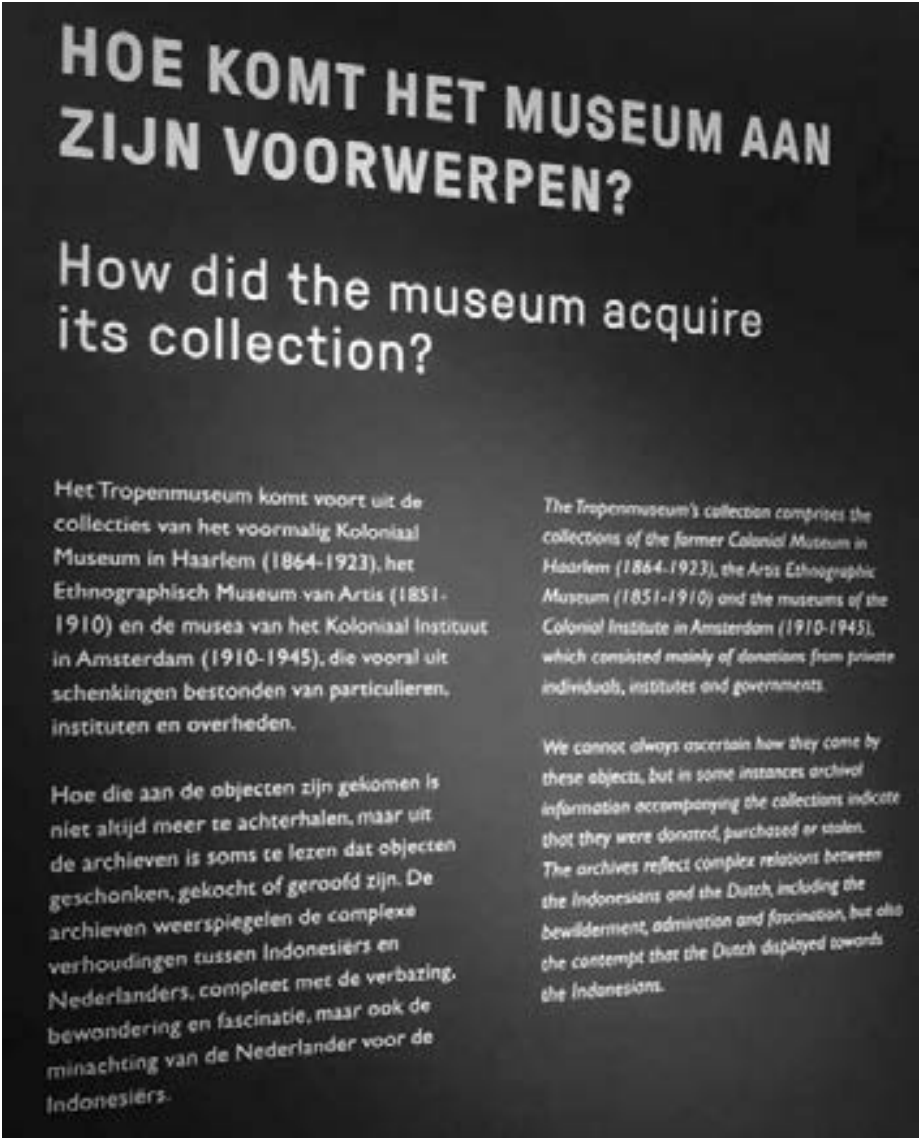

Tropenmuseum; photo by Csilla E. Ariese, 2019

related to the exhibition and the museum itself. They drew attention to the asymmetries in representing the perspectives of colonizers and colonized; to the lack of information about the violence and exploitation colonialism entailed; and to the museum's failure to adequately present how colonized peoples resisted. In response, in 2016 the museum organized a conference titled Decolonize the Museum. This enabled the Decolonize the Museum group to place a few text panels next to the original wall panels. These new panels contained critical descriptions that offered alternative views on the exhibition. They revealed what was invisible in the exhibition, namely colonial violence and exploitation, as well as the role of the museum itself in acquiring objects that had been stolen or otherwise taken as trophies. 
The new texts were displayed for several months. Following their removal, the curators and activists began to cooperate intensively on the writing and editing of new museum texts. Since then, the curators have added these and other new texts to the older exhibits in order to make visible what was invisible before: the perspectives of colonized peoples.

\section{Mutare Museum | Mutare, Zimbabwe}

Mutare Museum is one of five museums administered by the National Museums and Monuments of Zimbabwe. It was opened in 1957 as Umtali Museum, when it was deeply rooted in the colonial regime. It consisted of five parts devoted to different topics: transport, geology, botany, antiquities, and ethnography. The latter, which was located in the Beit Gallery, contained objects obtained from source communities, presented as a random collection of various groups of artefacts without any contextual information: transport accessories, zoological and botanical objects, traditional beehives, geological displays, and traditional objects, such as drums. The last group of objects proved to be the most significant for curators who were working on the rearrangement of the gallery. Jindwi traditional drums had been 'collected' during the colonial period by ethnographers who wished to study the culture of the 'African other,' yet lacked a proper grounding in these drums' social and cultural functions and the important associations with their makers.

The Jindwi drums were displaced from their original context and replaced in the museum's glass cases, thereby becoming objects of colonial ethnography that were assigned new colonial meanings based on colonial scientific, historical, and aesthetic paradigms of Western knowledge. In the imperial realm of significance, the drums were no more than material objects referring to the 'exotic, primitive, and distant' African culture, but in the Jindwi community's realm of significance, these same drums were important symbols of identity. For this reason, the museum was criticized by this community for being an alien entity, imported from the empire, that was elitist, urban-based, and above all served colonial interests.

A reorganization of the ethnographic collection took place in 2016. One of the curators, Njabulo Chipangura, declared that decolonization was one of the most important aims and this was examined from various angles. ${ }^{9}$ Firstly, the imperial policies that had facilitated the looting of drums belonging to the Jindwi community were critically examined by curators. But more importantly, decolonization was understood as "a movement away from 
Western traditional object-oriented approaches in museums into becoming spaces of interactive engagement between various cultures. ${ }^{10}$ Curators aimed to achieve a deeper understanding of local cultures and to invite the participation of dispossessed communities. The exhibition project started with research that revealed the importance of music for Eastern Shona people. Music forms part of their traditions in ritual ceremonies (like hunting ceremonies or rain rituals), as well as everyday activities such as cultivating, harvesting, joyful occasions, or funerals.

The exhibition curators observed that dances formerly performed by the Jindwi during ritual ceremonies had transformed into social dances for parties and other occasions. They also realized that the Jindwi were still using the same traditional drums as those found in the museum exhibitions, so they started to look for methods of bridging the gap between the static objects displayed in the museum and similar objects being used in community ceremonies. In the revamped Beit Gallery, which was opened in June 2016, specific songs and dances are explained alongside the social events they relate to and short videos of traditional musical performances are shown. According to the curators, "the new exhibition uses both audio and video depictions to illustrate the socio-cultural uses of the drums that were discursively collected when this museum was opened in $1964 .{ }^{111}$ They argue that the objects should not be separated from beliefs, values, ideas, attitudes, and assumptions of African society. And even if they finally used some well-known museum means and methods, the exhibition reveals a different realm of significance, one that is truly important for local communities to share with the wider public.

\section{Belmont Estate | Belmont, Grenada}

The Belmont Estate (BE) on the Caribbean island of Grenada was opened to the public in 2002. ${ }^{12}$ It is a former plantation estate, including extensive grounds as well as several buildings with diverse functions. Unlike many other plantations throughout the Caribbean that have been turned into heritage and tourism sites, the focus of the BE is not on its 'great house' or villa. Indeed, there is no great house to visit. Instead, the concept of the

10 Chipangura and Chiripanhura 2017: 229.

11 Chipangura and Chiripanhura 2017: 235.

12 Following the destruction of much of the estate due to Hurricane Ivan, it was closed from 2004 to 2007. 
owner, Shadel Nyack Compton (who is a Grenadian of East Indian origin), is centered around agri-tourism. ${ }^{13}$

During the colonial era, much of the Caribbean region was characterized by plantation estates, with some islands being almost entirely divided into plantation parcels of land. Grenada, still known today as the spice island, was particularly used for the production of nutmeg, unlike many other islands which were mostly used for planting and harvesting sugar cane. This long-term and often violent colonial exploitation of the Caribbean - in terms of both the careless exploitation of the environment and the ruthless exploitation of the labor and lives of enslaved persons - has left many scars on the region's landscapes today and in the lives and memories of its populations.

Thus, contemporary relationships with plantation estates are complex. For the descendants of enslaved persons, they are sites of trauma and of grief, but often also sites of ancestral homes or huts and burials. Yet they are also popular heritage sites for local governments and sometimes also local communities. The great houses are frequently built in aesthetically pleasing locations with grand views and the buildings themselves are spacious, 'beautiful' according to European standards, and often heritage-listed. Few other kinds of historical buildings in the region have been preserved as often as great houses and once they are listed as cultural heritage sites their use becomes limited. As a result, many Caribbean plantations and their great houses can be visited today as museums. Some of these museums deal transparently and vulnerably with their history as a place of enslavement, violence, and exploitation. They may present stories of present-day descendants of enslaved persons who used to work on the estate or information about historical uprisings and revolts. Others focus instead on the histories of the colonizers who formerly lived in the great house. Such museums commonly present period-style rooms decorated with antique furniture. Still others focus solely on the production processes of sugar cane and rum, thereby entirely avoiding any connection to human histories and denying any ties to slavery and the trade in enslaved persons.

Within this broad range of different plantation tourism approaches, the Belmont Estate chooses to focus on increasing the visibility of the Grenadian environment and on advocating sustainable agricultural practices by leading through example. The estate grows many different kinds of spices, including of course nutmeg, which are used in its restaurant in typical Grenadian dishes. The BE also grows and produces organic cocoa and offers special 
Figure 1.2 The focus is on caring for the plantation estate's landscape rather than preserving its colonial mill

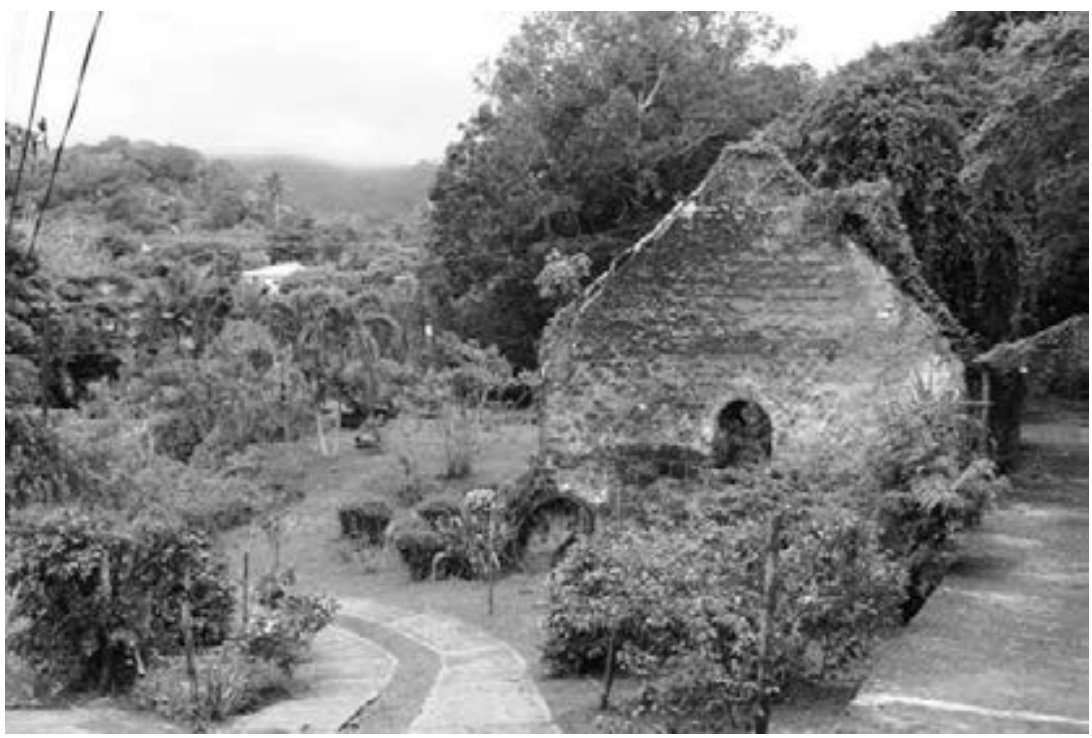

Belmont Estate; photo by Csilla E. Ariese, 2014

'from bean to bar' tours. The landscape of the estate is really the focal point for any visit, whether one tours the tropical garden, the fruit orchards and vegetable gardens, the animal enclosures, or the modern workings of the estate and its produce. All of these parts are accompanied by informative signs that focus on flora and fauna, mixed with culinary and medicinal traditions. BE has also offered a home to the Grenada Goat Dairy Project to support their mission of producing local goat cheese and empowering low-income farmers. Similarly, a small building is used by the Grenada Arts and Crafts Co-op for demonstrations and as a gallery. Finally, the BE contains a small museum building, which documents Grenadian traditional lifestyles as well as the history of the estate.

The BE practices decoloniality primarily by creating visibility for sustainable and fair agricultural practices - both in terms of the environment and their laborers. In doing so, it counteracts on a small, local scale the historical colonial destruction and exploitation of landscapes. Additionally, the Belmont Estate does not participate in the so-called 'neo-colonialism' of modern day tourism, by which choice landscapes and sites are purchased commercially for hotels, wellness centers, and so on, without considering the long-term strain on the environment or the negative impacts on 
contemporary populations. ${ }^{14}$ Instead, the BE focuses on the wellbeing of its community first and foremost: ensuring a sustainable environment, providing fair employment, and also supporting literacy, language, and health programs through its charity.

\section{Further reading}

Decolonizing Museums: Representing Native America in National and Tribal Museums | Amy Lonetree | 2012

Duress: Imperial Durabilities in Our Times | Ann Laura Stoler | 2016

The Interrogative Museum | Ivan Karp and Corinne A. Kratz | 2015

Zimbabwean Museums in the Digital Age: A Quest to Increase Museum Visibility in Public Space through Social Media | Munyaradzi Mawere and Genius Tevera | 2015

\section{Further examples}

Identity: Yours, Mine, Ours exhibition at the Immigration Museum

Melbourne, Australia (opened 2011)

"What does it mean to belong and not belong in Australia? This exhibition explores how our cultural heritage, languages, beliefs, and family connections influence our self- perceptions and our perceptions of other people - perceptions that can lead to discovery, confusion, prejudice and understanding." 5

With our thanks for this suggestion to Britta Timm Knudsen.

Lande: The Calais 'Jungle' and Beyond exhibition at the Pitt Rivers Museum Oxford, UK (April-November 2019)

"The exhibition reassembles material and visual culture that survives from the 'Jungle' as it existed at Calais from March 2015 to the demolitions of 2016. It does so in order to make visible the landscape of 'borderwork' at Calais. These range from photographs and artworks made by displaced people and undocumented children to images made by activists and

14 Williams 2012.

15 As quoted from the Immigration Museum website. Available at https://museumsvictoria. com.au/immigrationmuseum/whats-on/identity-yours-mine-ours/ (accessed 1 April 2021). 
artists, and from the Calais cross salvaged from the Orthodox Church at the 'Jungle' to a fragment of border fencing."

With our thanks for this suggestion to Britta Timm Knudsen.

\section{African Presence in Finland exhibition at the Finnish Labour Museum}

Tampere, Finland (April-November 2015)

"The exhibition project provided new knowledge of the African diaspora communities' contributions to Finnish society and culture. It also enabled an examination of many theoretical questions concerning research on African and black diaspora(s) in Europe, including those focusing on African diaspora formations in a Northern European country with a relatively short history of migration from Africa and its global diaspora. ${ }^{177}$ The project is also discussed in an audio series. ${ }^{18}$

With our thanks for this suggestion to Lorena Sancho Querol.

Unheard Voices: Slavery, Gender, Migration and Diversity in the Allard Pierson audio tour at the Allard Pierson

Amsterdam, the Netherlands (February-March 2019)

A temporary audio tour developed by students of the University of Amsterdam.

"This tour highlights nine objects creating an alternative route through the collection, which allows forgotten voices from the past to be heard again [...] The tour Unheard Voices offers an extra layer that brings forward identities silenced since the ancient past."19

Засушенному - верить [Believe in the Dried] project and travelling exhibition Various locations, Russia (2017-2020)

This Russian exhibition is based on herbarium sheets which can be read to tell the stories and journeys of persons displaced by the GULAG, providing voices for those who have since died and who have rarely been recorded previously.

"This exhibition is about memory, fragility and implicit traces. The eye slips by until we know that these are footprints. People are leaving, the

16 As quoted from the Pitt Rivers Museum website. Available at https://www.prm.ox.ac.uk/ event/lande (accessed 1 April 2021).

17 As quoted from researcher Anna Rastas' website. Available at http://www.annarastas.com/ the-african-presence-in-finland-action-research-project-and-exhibition/ (accessed 1 April 2021).

18 The audio series is available at https://soundcloud.com/projectosomus/sets/somus-2-theafrican-presence-in-finland-flm (accessed 1 April 2021).

19 As quoted from the Unheard Voices booklet. 
grasses-displaced persons also disappear, but the herbarium sheets remain - a document confirming that there were displaced persons - people and herbs. Botanists at the exhibition are translators deciphering the 'language' of plants. [...] All of them prepared the leaves of the herbarium and the stories associated with them: carnations from the runway of the Moscow airfield, a green carpet of herbs in the place of the women's branch of the Norillag, five stems hanging upside down from the collections of a naturalist who spied on the Decembrists and Pushkin, sheets of Solovetsky prisoners, living human stories and survivor of wars and displacements." ${ }^{20}$ With our thanks for this suggestion to Daria Agapova.

\section{References}

Ariese, Csilla E. 2019. The Social Museum in the Caribbean: Grassroots Heritage Initiatives and Community Engagement - Appendix: Caribbean Museums Database. Leiden: Leiden University Repository.

Bennett, Tony. 1995. The Birth of the Museum: History, Theory, Practice. London: Routledge.

Bourdieu, Pierre. 1993. The Field of Cultural Production: Essays on Art and Literature. New York: Columbian University Press.

Castro, Fernanda; Magalhães, Aline Montenegro; Sancho Querol, Lorena; Severo, Rosário; and Botas, Ana. Forthcoming. "Decolonial Educational Practices at National Museums in Rio de Janeiro and Lisbon: Towards a Comparative Study." Revista de Estudos Ibero-Americanos.

Chipangura, Njabulo. 2020. "Co-curation and New Museology in Reorganizing the Beit Gallery at the Mutare Museum, Eastern Zimbabwe." Curator 63.3: 431-446. DOI: doi.org/10.1111/cura.12375.

Chipangura, Njabulo, and Chiripanhura, Pauline. 2017. "Reconfiguring the Jindwi Traditional Drums in a Post-colonial Mutare Museum Setting." In Nhemachena Artwell, Jairos Kangira, and Nelson Mlambo, eds. Decolonisation of Materialities or Materialisation of (Re-) Colonisation? Symbolism, Languages, Ecocritism and (Non) Representationalism in 21st Century Africa. Bamenda: Langaa RPCIG. 219-240.

Chipangura, Njabulo, and Mataga, Jesmael. 2021. Museums as Agents for Social Change: Collaborative Programmes at the Mutare Museum. London: Routledge.

20 As quoted from the Zasushennye website (in Russian, machine-translated through Google). Available at http://zasushennye.ru/vystavka/ (accessed 1 April 2021). 
Karp, Ivan, and Kratz, Corinne A. 2015. "The Interrogative Museum.” In Raymond A. Silverman, ed. Museum as Process: Translating Local and Global Knowledges. London and New York: Routledge. 279-298.

Lonetree, Amy. 2012. Decolonizing Museums: Representing Native America in National and Tribal Museums. Chapel Hill: The University of North Carolina Press.

Mawere, Munyaradzi, and Tevera, Genius. 2015. "Zimbabwean Museums in the Digital Age: A Quest to Increase Museum Visibility in Public Space through Social Media." In Munyaradzi Mawere, Henry Chiwaura, and Thomas Panganayi Thondhlana, eds. African Museums in the Making: Reflections on the Politics of Material and Public Culture in Zimbabwe. Bamenda: Langaa RPCIG. 247-268.

Pomian, Krzysztof. 1994. "The Collection: Between the Visible and the Invisible." In Susan M. Pearce, ed. Interpreting Objects and Collections. London and New York: Routledge. 160-174.

Prakash, Gyan. 1992. "Science 'Gone Native' in Colonial India.” Representations 40: 153-178.

Stoler, Ann Laura. 2016. Duress: Imperial Durabilities in Our Times. Durham, NC: Duke University Press.

Van Huis, Iris. 2019. "Contesting Cultural Heritage: Decolonizing the Tropenmuseum as an Intervention in the Dutch/European Memory Complex." In Tuuli Lähdesmäki, Luisa Passerini, Sigrid Kaasik-Krogerus, and Iris van Huis, eds. Dissonant Heritages and Memories in Contemporary Europe. Cham: Palgrave Macmillan. 215-248.

Williams, Tammy Ronique. 2012. "Tourism as a Neo-colonial Phenomenon: Examining the Works of Pattullo \& Mullings." Caribbean Quilt 2: 191-200. 



\title{
2 Increasing Inclusivity
}

\author{
Csilla E. Ariese
}

\begin{abstract}
Historically and traditionally, museums have been closed spaces and realms of elites - whether cultural, religious, aristocratic, or intellectual elites. Making the museum public, and opening it up to audiences and visitors, has been an ongoing process since the late 19th century. Particularly since the 1970s, increasing inclusivity has been a core goal of the ever-increasing social role of the museum. The ideal is to involve non-museum actors in every part of the workings of the museum, so that the museum does not speak for others but as others. However, in the worst cases, these intentions can result in tokenistic inclusion or exploitation.
\end{abstract}

Keywords: co-creation, participation, community engagement, the social museum

Inclusivity is the inclusion of non-museum voices, actors, or decisions into the workings of the museum.

\section{The challenge}

Throughout history, museums and their predecessors, such as sacred store houses and cabinets of curiosities, have been in the hands of elites. In parts of Asia, sacred items with special meaning and value were kept safe by elders in store houses. ${ }^{1}$ In Europe, the early cabinets of curiosities were created by royalty, aristocrats, and religious leaders. These displays could only be visited by elites of similar standing - mainly men - and on appointment. ${ }^{2}$

$1 \quad$ Kreps 2011.

$2 \quad$ Findlen 1989.

Ariese, Csilla E., and Magdalena Wróblewska, Practicing Decoloniality in Museums: A Guide with Global Examples. Amsterdam, Amsterdam University Press 2022 DOI: 10.5117/9789463726962_CHO2 
Over the following centuries, most collections were amassed by societies' minority elites, such as academic societies (for example anthropologists, geologists, botanists) or the wealthy (e.g. colonizers, traders, aristocrats). Engaging in collecting was something that only elites/elders could do, as they had the funds, opportunity, connections, prestige, and time.

The birth of the 'modern' museum marks the time when museums physically opened up to accept non-elite visitors. ${ }^{3}$ It is in this period, roughly the 19th century, that museums sought to welcome 'regular' visitors. Inspired by the Great Exhibitions held contemporaneously in various places around the world, museums tried to get 'common folk' to visit. Colonial-era notions played into this change. Museums were thought to be places where the general population could be 'educated' and 'civilized' - both by the objects and information on display as well as by rubbing shoulders with/being observed by other visitors.

With such a history, it is perhaps little wonder that museum institutions are traditionally rather closed spaces. Although they are open to visitors, this openness is quite limited. Visitors can only enter on certain days and times, often for an entry fee, and their behavior is monitored and directed by social norms as well as sometimes by floor staff. Much of the museum staff - invisible within the back-offices and storage spaces - is artificially separated from the visitors. As a result, museums gained the reputation of being unwelcoming, elitist institutions, so-called 'temples of knowledge,' not suitable for everyone.

This perception has been shaken up since the 1970s. Museums should be open, welcoming, and inclusive for all! Many museums receive government funding; if taxes pay for these institutions, surely all members of society should feel welcome inside and represented by them. Many museums represent people; if they do, surely it is best for people to represent themselves, rather than for others to speak on their behalf. Many museums have objects that used to belong to people who may not have given permission - informed consent - for their collection and display; perhaps they would like some of these objects returned or displayed/stored in other ways? Increased inclusivity, involving non-museum staff or new museum staff in the activities of the museum, responds to these issues.

The abovementioned challenges to the museum have shaken the concept of the museum institution to its very foundation. Inclusivity is a way to add voices, actors, and agents into the workings of the museum. However, as complex institutions that have worked in a specific way for centuries, 
museums are finding it hard to be more open and inclusive, fearing that they might lose their own voice or authority in the process.

\section{The change}

Increasing inclusivity in the museum begins with identifying exactly whom the museum wishes to include (more/better). Let's explore a few scenarios.

If a museum is noticing low visitor numbers, surveys may show that this is because people living nearby the museum do not know about it or cannot afford to visit it. If the museum wants to be more inclusive to this neighborhood community, it could consider changing entry fees for local visitors. Alternatively, perhaps changing the façade of the museum to more clearly show that this community is welcome to enter that space. ${ }^{4}$ In this manner, working towards increasing inclusivity can lead to more visitors from the neighborhood.

Perhaps a museum is planning an exhibition about youth culture and gaming, because they wish to be more inclusive thematically to younger audiences. The museum could create this exhibition in-house, but the exhibition would be more inclusive if members of the perceived target audience were also part of the exhibition creation process. They will have better knowledge of the subject matter and may also do a better job at evaluating how peers may experience and enjoy the exhibition. Along the way, they can steer the exhibition to be more inclusive not just in its development but also in its final form.

As a third example, an exhibition on a contested subject may spark debate among visitors and in the media or on social media. In such a case, many people will have something to say about the conversation ignited by the museum and the exhibition team. The museum can adjust to this (possibly unexpected) response by creating a space where visitors can add their own voices directly in the exhibition. Beside a basic guestbook, specific prompts or questions can encourage people to respond. Leaving these responses visible also increases the inclusivity of the exhibition, by allowing more people to have their voices encompassed within it.

Increasing inclusivity will always need to begin by identifying whom to include and how such inclusion can be achieved. Another important consideration is whether inclusivity with this person or group is for a short or long period of time. Asking someone to participate in a focus group 
interview for a museum program is relatively shallow inclusion, whereas hiring someone specifically as a representative of a certain community, for instance, reveals a more long-term intent.

It is important to point out, however, that inclusivity may be (perceived as) tokenistic. ${ }^{5}$ The staff member hired to represent a community, for instance, may feel as if they are hired only for appearances if their opinions are not actually taken into consideration. If persons are asked to participate in the workings of the museum, but their work is not valued, not used, or not credited, clearly the aim to increase inclusivity has failed. Participants will have been included but they lacked any real power. As a second point, being more inclusive does not necessarily mean decentering. In fact, voices can be added which serve to strengthen the norm rather than contest it.

Being more inclusive means giving up authority and power to new actors, for brief or long periods of time. It will require monitoring, feedback loops, and adjusting to ensure that the goal for increasing inclusivity is being met - without being to the detriment of the participants.

Too often, people of colour are rolled in to provide natural resources - our bodies and our 'decolonial' thoughts - which are exploited, and then discarded. The human cost, the emotional labour, are seen as worthy sacrifices in the name of an exhibition which can be celebrated as a successful attempt by the museum at 'inclusion' and 'decolonising.' 6

\section{Corona in the City $\mid$ Amsterdam Museum | Amsterdam, the Netherlands}

The Amsterdam Museum (AM) is a city museum which was founded in the early 2oth century. Many of its collections, however, are older. Significant group portraits and décor from (former) municipal buildings, as well as legacies and gifts from collectors, were created or amassed well before the museum was founded. Furthermore, since the founding of the museum, curators and staff have also engaged in more contemporary collecting. As a result, the collections are incredibly diverse, containing artworks, crafts, and objects of everyday use, all of which can in one way or another be tied to the city of Amsterdam and its inhabitants.

Today, the heart of the museum is housed in a former civil orphanage in the city center. Additionally, the museum rents a permanent exhibition 
space at the Amsterdam Hermitage, and also operates the historical canal house Museum Willet-Holthuysen. Furthermore, through collaborations with other institutions, regular exhibitions and events are held in other parts of the city or in public spaces. The photo exhibition Women of Nieuw-West (2019-2020) was visible outdoors in several parts of the city, starting in the neighborhood Nieuw-West where the portrayed women are residents.

Visitor numbers from the early 2010 s had shown that a large majority of the museum's visitors were tourists, while Amsterdammers made up less than $10 \%$ of the visitors. The museum decided to refocus their mission and vision to become a space where Amsterdammers would feel more welcome and represented. This meant a deliberate shift towards more local visitors by ensuring that the museum would be more inclusive towards them. Exhibitions such as Women of Nieuw-West fit within this strategy, enabling local residents to be both the exhibition's subject and intended audience. In addition, the museum has had several contemporary collecting projects to ensure that Amsterdammers from different cultural, religious, or neighborhood groups would be better represented in the museum's collections.

As a result of the Covid-19 pandemic, all museums in the Netherlands were closed from mid-March 2020 until the beginning of June 2020. Lacking the opportunity to receive visitors on-site, the AM decided ad hoc to create, together with 40 partner organizations, a digital collection and an online exhibition: Corona in the City. It sought to collect how Amsterdammers personally experienced the crisis and the first lockdown. Anyone could submit their digital media (text, image, audio, or video). The AM gathered all submissions in a digital collection which is accessible via a website. Additionally, selected submissions are also curated online into galleries. Although some of these galleries were curated by museum staff, the museum also asked other (cultural) institutions, individuals, artists, journalists, and other parties to curate their own gallery. For example, curator Imara Limon created the gallery Black Lives Matter, ${ }^{7}$ documentary photographer Willemieke Kars the Female Gaze Goes Viral gallery, and Amsterdam Cares was curated as a collaboration between the Florence Nightingale Institute and Pulse Network Medical \& Health Humanities.

The digital collection and online exhibition were opened on 15 May 2020 and were accompanied over the first six weeks by a weekly online program.

7 This gallery contains the works of photographer Luciano de Boterman taken during a Black Lives Matter protest held in the summer of 2020 in Amsterdam. The photographs were purchased by the Amsterdam Museum and curator Limon created both an online and an offline exhibition with them. 
Figure 2.1 Selected photographs from Black Lives Matter Amsterdam were also exhibited offline in the free-to-visit courtyard of the Amsterdam Museum

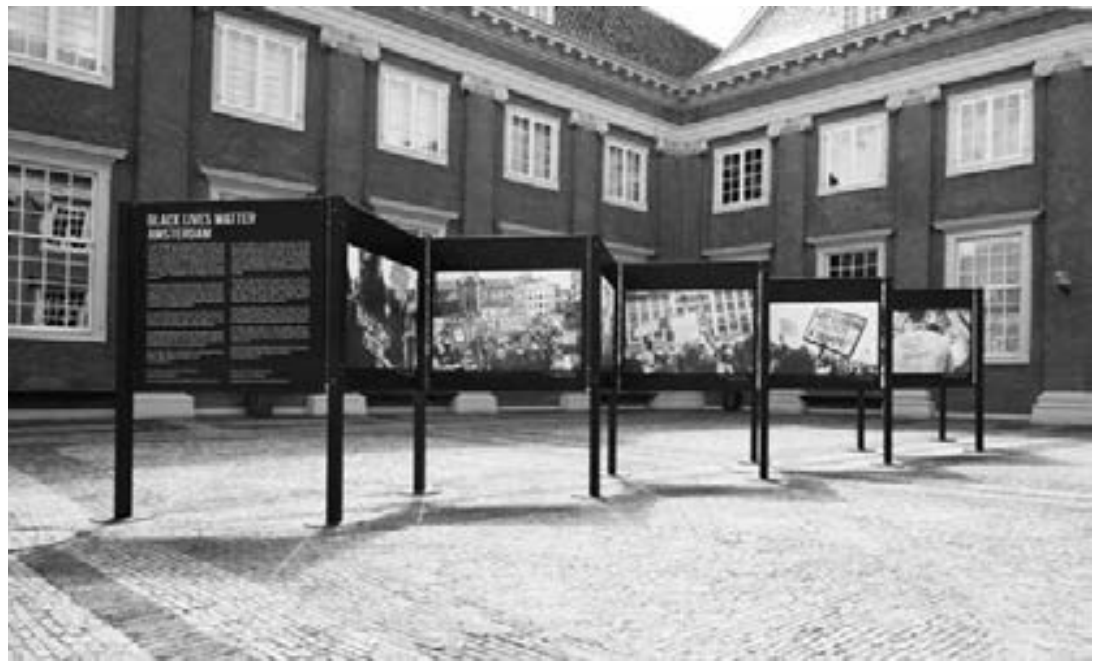

Photo by Amsterdam Museum, Monique Vermeulen, 2020

The program consisted of a conversation between staff and invited guests, launching the 'opening' of new galleries. Corona in the City is inclusive on several levels. On the one hand, anyone can visit the exhibition and collection at any time, from anywhere in the world, for free; by 26 June 2020 it had attracted over 50,000 visitors. On the other hand, it is entirely the result of contemporary participatory collecting, mainly by Amsterdammers, (over 1,300 submissions by 26 June) and is also in part created through participatory curating. Although the AM controls which content is accepted into the collection, the threshold for participation is relatively low and there are few real barriers to inclusion or participation.

\section{GLOW | Santa Cruz Museum of Art \& History | Santa Cruz, USA}

The Santa Cruz Museum of Art \& History (MAH) was created out of the merger of the Santa Cruz Historical Society (founded in 1954) and the Art Museum of Santa Cruz County (1981) and opened its doors in 1992. It was intended as a community center for the county of Santa Cruz, combining its arts and histories. However, the economic downturn in the early 21st century strongly impacted the museum. 
Nina Simon began as Executive Director of the MAH in 2011. Her vision was to change the museum's purpose: "from being a place for art and history to a place that uses art and history to build community." ${ }^{8}$ The focus was thus placed on creating relevance for the county and to reflect the diversity of its community. Now, the "MAH is of, by, and for Santa Cruz County because our creative community ignites something new here every day." ${ }^{9}$ By 2020, the museum's annual visitor numbers had increased from 17,000 to 95,000.

Simon's approach entailed a complete change of the museum. She hired new staff and gave them tasks and job titles such as Learning \& Engagement Manager, Director of Community Engagement, and Outreach Coordinator. The MAH focused more on public programming and community engagement than on traditional exhibitions: it now holds about 600 events per year. It created opportunities for volunteers and interns to work at the museum and for community members to use the space, whether for a performance, a teen program, or yoga classes. It has fostered partnerships throughout the county. The MAH achieves what it does thanks to its community and has become a cornerstone of that same community.

Stacey Marie Garcia, previously MAH's Director of Community Programs, was in charge of many of the public programs and events organized by the MAH and to create new and maintain existing partnerships with members of the community and its organizations. One of Garcia's innovations was to hold themed Third Friday events, any of which may mean working together with 30 to 150 different organizations. ${ }^{10}$ These events are highly participatory, containing performances and stations where people can create, explore, enjoy.

Perhaps most successful has been GLOW, an annual festival of fire and digital art. ${ }^{11}$ GLOW has become one of the biggest arts festivals in the county but started as an idea proposed by the local Burning Man community in 2012. The festival takes place on one night - previously two nights - and brings partners and community members from the entire county together. Each year, different artists and persons are featured. In 2019, GLOW included artworks, installations, and performances by 35 artists/collectives.

Through GLOW, Third Fridays, and other events, the MAH has succeeded in dramatically increasing its inclusivity. More and more organizations,

8 As quoted from the Santa Cruz Museum of Art \& History website. Available at https://www. santacruzmah.org/history (accessed 1 April 2021).

9 As quoted from the Santa Cruz Museum of Art \& History website. Available at https://www. santacruzmah.org/about (accessed 1 April 2021).

10 Simon 2013.

11 For two video impressions of GLOW, see Hoff 2015 or Santa Cruz MAH 2013, linked in the reference list. 
Figure 2.2 GLOW: A Festival of Fire \& Light

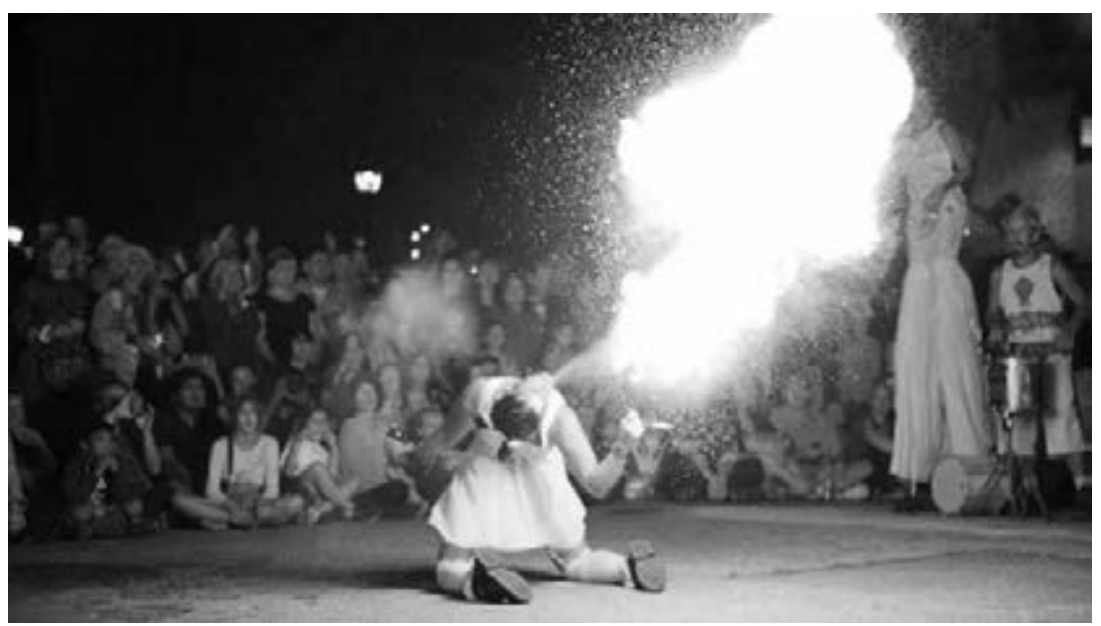

Photo by the Santa Cruz Museum of Art \& History (MAH), 2014

artists, and community members have been able to express themselves, make themselves at home, explore art and history, and engage with others within the space of the MAH.

\section{Museum of London | London, UK}

The Museum ofLondon (MoL) documents and exhibits the history of London from its prehistoric settlement until today. It was opened in 1976 after the collections of two other museums were amalgamated: the Guildhall Museum (opened in 1826) and the London Museum (opened in 1912). The MoL is planning to move to a new museum site, estimated to be completed in 2024. Additional exhibition space on the new site will allow for more of the collections to be on display. The collections contain over 7 million objects and are, typically for a city museum, diverse in terms of age, material, type, size, and context.

The museum has eight permanent galleries, which are chronologically divided. The path through the museum meanders through each of these galleries in order, beginning with London Before London (450,000 BCE-5o CE) and ending with World City (1950s-today). Each gallery has its own design, narrative, and tone of voice, which offered their respective curatorial teams the freedom to experiment uniquely in each gallery. Beyond unique visual designs and interactive displays, these experiments also showcase various practices to increase inclusivity. 
Figure 2.3 We are going on a mammoth hunt

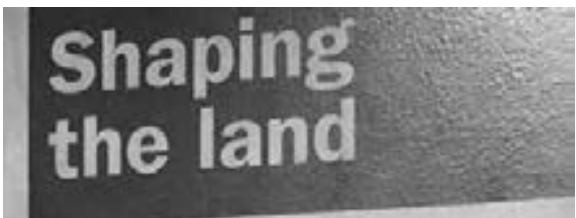

The landmass was dominated by climate change on a global scale. Ice sheets advanced and retreated. Sea levels rose and fell. Most of the time Britain was a remote peninsula of Europe; occasionally it was an offshore island.

The Thames shaped the London region. but it had not always done so. It had once flowed well to the north and entered the North Sea as a tributary of the Rhine.

Around 450,000 years ago $x$ moving wall of ice tipped the river into its present valley. Gradually it adjusted its course and level to accommodate fluctuations in climate and sea level.

Different species of early humans were intermittently present. Initially they favoured warmer climates and avoided the great northern ice sheets. Later. however, Neanderthal groups chose to hunt on open steppe grasslands, where they could see and be seen.

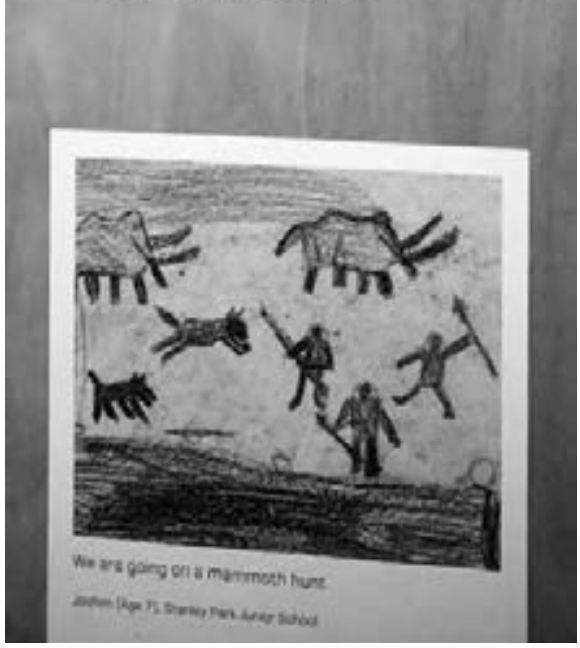

Museum of London; illustration by Joshim; photo by Csilla E. Ariese, 2019 
In the first gallery, London Before London, objects on display are all archaeological. Because only some kinds, or some parts, of objects have been preserved, understanding this era of London's past requires quite some imagination. The exhibition team uses several techniques to support visitors and their imaginations. For instance, a reconstructed clay head of a woman, next to her fragmentary skeletal remains. Or a large photograph of an experimentally rebuilt roundhouse. Or a diagram and model showing the construction of a wooden pathway. These tools help visitors see beyond fragmentary evidence of the past to be able to envision the past more clearly. Additionally, they have also invited others to share their personal viewpoints. Several poems by Bernardine Evaristo, the MoL's poet-in-residence, reveal her perception of this time period, its landscape, animals, and plants. Another collaboration reveals the colorful participation of primary schools. Main panel texts, for instance about the river Thames, are accompanied by drawings by young pupils. Pupils from the Beecroft Primary School were furthermore asked to create a larger artwork, Gifts to the Water, which illustrates "how objects from the Neolithic period found their way into the Thames (left) and what special objects they might offer to the river today (right). ${ }^{{ }^{212}}$ These artworks - in words and in images - all engage with the content of the exhibition and the objects on display, but do so from different (outsider) viewpoints.

As a final example of inclusivity in the MoL, the Roman London gallery (50-410 CE) permanently displays the results of ephemeral activities. A curator and a professional poet accompanied groups of young poets on a "psycho-geographical tour of the city. Writing as they travelled, these poems express their thoughts on the legacies of Roman London that can still be felt today. ${ }^{13}$ These 18 poems are displayed as an integral part of the exhibition and provide multiple perspectives on Roman London, its remains in the present city landscape, and objects in the museum. Thus, the museum has increased inclusivity by including the perspectives of others: the work of a poet-in-residence, the verses of young poets, and the illustrations of children.

\section{Liberty Hall: The Legacy of Marcus Garvey | Kingston, Jamaica}

Situated in downtown Kingston, Liberty Hall: The Legacy of Marcus Garvey is a multi-media museum that opened to the public in 2003. Marcus Garvey was a Jamaican political activist who in 1914 founded and led the Universal

12 Gifts to the Water object label, London Before London gallery, Museum of London (as seen in 2019).

13 Poetry wall label, Roman London gallery, Museum of London (as seen in 2019). 
Negro Improvement Association and African Communities League (UNIA). Ideologically, he was a Pan-Africanist and believed in the Back-to-Africa movement. Furthermore, he was committed to improving the financial independence of those of African descent. Yet he was also a controversial figure, as he supported racial separatism rather than integration. Nonetheless, for his positive encouragement of pride and self-worth in those of African descent, he was awarded the honor of the Order of National Hero in Jamaica.

The museum's primary mission is to inform the public about the work of Marcus Garvey and to "use his philosophy and opinions to inspire, excite and positively affect the self-identity of Jamaican people, while creating social and economic wealth." ${ }^{\prime 4}$ The museum is housed in Liberty Hall, a building which was purchased by the UNIA in 1923 as the headquarters of its Kingston division. It was the first meeting hall in Jamaica to be fully owned and operated by black persons. Liberty Hall was the site of plays, concerts, and dances, but was also a place of education where educators, social workers, women's rights activists, and teachers organized meetings and classes. The building was declared a national monument in 1992 for its historical significance and is maintained by the Jamaica National Heritage Trust.

Today, Liberty Hall exists in a similar spirit and contains similar functions. The multi-media museum details the history and message of Garvey, the UNIA, and particularly the histories of those of African descent in Jamaica. Its message is clearly anti-colonial and intends to raise up 'the downtrodden.' It works towards increasing inclusivity by making those of African descent feel empowered and valued, and by showing examples of positive representation.

Liberty Hall also contains an extensive reference library and a computer center. In both of these, classes and courses are offered to children and adults alike. For instance, reading and writing classes are offered to improve literacy for those in need, regardless of age. For adults, computer classes are offered with a particular focus on job searching, writing resumes, and submitting job applications. As such, Liberty Hall operates within the spirit of Marcus Garvey to ensure that its target communities can increase their social and economic wealth. It provides inclusion that extends beyond the building itself. Liberty Hall aims for its visiting communities to be able to include themselves more confidently and strongly in Jamaican society as a whole.

14 As quoted from the Liberty Hall: The Legacy of Marcus Garvey website. Available at https:// liberty-hall-the-legacy-of-marcus-garvey.business.site/ (accessed 1 April 2021). 
Figure 2.4 Garvey, Family and Community, mosaic mural created by students during the 2005, 2006, 2008, and 2010 Summer Art Programmes

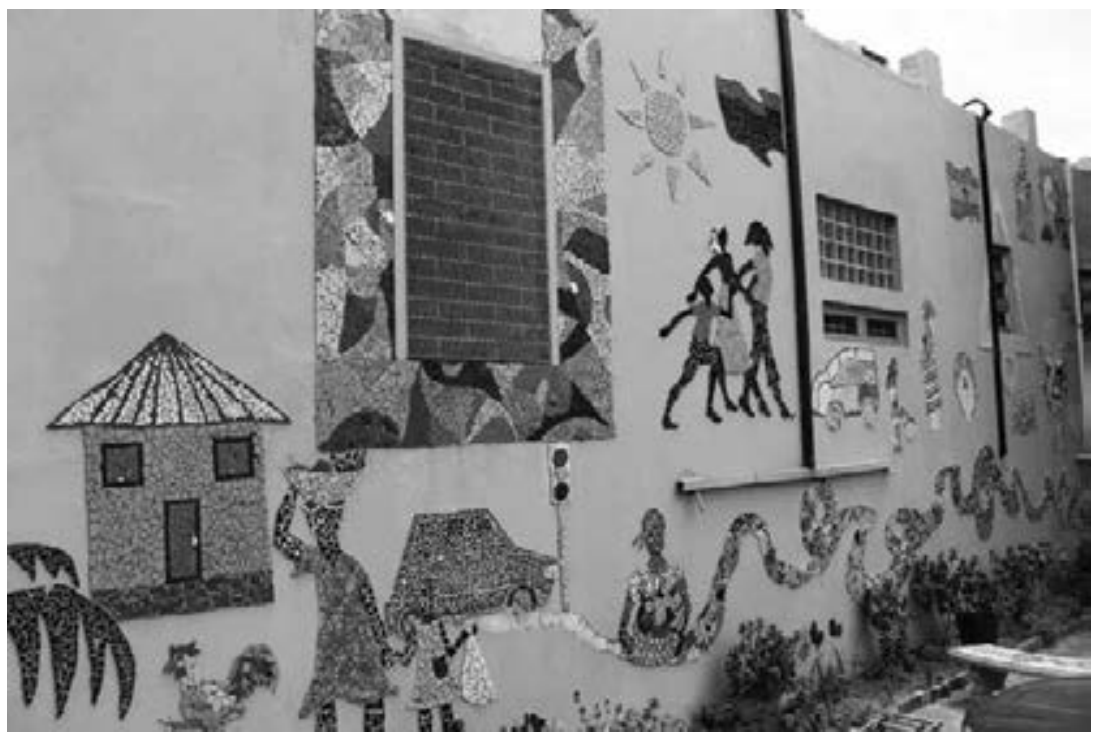

Liberty Hall courtyard; photo by Csilla E. Ariese, 2014

Finally, Liberty Hall also offers its community opportunities to gather and be together for educational or social events. Its Great Hall can be used for all sorts of public functions, such as symposiums or cultural events, but it can also be used by people wishing to host an outreach program. With all its components, Liberty Hall combines a museum, a library, a computer room, and a community center. It fits into the category of a holistic ecomuseum, which "is foremost a community and an objective: the development of that community."'5

\section{Further reading}

Ecomuseums and Cultural Landscapes: State of the Art and Future Prospects | edited by Raffaella Riva | 2017

The Art of Relevance | Nina Simon | 2016

The Participatory Museum | Nina Simon | 2010 


\section{Further examples}

\section{Museum of Homelessness}

On streets in the UK (since 2015)

"Museum of Homelessness is a community driven social justice museum, created and run by people with direct experience of homelessness. $\mathrm{MoH}$ tackles homelessness and housing inequality by amplifying the voices of its community through research, events, workshops, campaigns and exhibitions. $\mathrm{MoH}$ also provides direct support - bursaries, mentoring, training and practical support - to its community members. Together we collect and share the art, history and culture of homelessness \& housing inequality to change society for the better. Together we find hope in deeply divided and difficult times. What our people say: 'It's had a huge impact on me, on my self-esteem. From a few years ago, when I felt invisible, like people didn't see me."'16

\section{Museos Comunitarios}

Mexico

Inspired by the New Museology and its focus on the social museum and the emphasis on culture as key for community development, since the 1970 s Mexico has seen the foundation of many community museums. ${ }^{17}$ Now numbering over 250, these community museums are important focal points for their communities in being able to preserve and share their heritages. Inclusivity is increased through this great wealth of separate yet connected community museums.

\section{Authentic Rotterdam Heritage program at the Museum Rotterdam}

Rotterdam, the Netherlands (since 2000)

“New Rotterdammers don't always see themselves reflected in our historical collection. That's why in 2000, we began working with local communities to start collecting and presenting objects that reflect life in today's Rotterdam. [...] Because the vehicle's owners [Bulgarian migrants] still needed it, we didn't want to keep the van as a museum object in our depot. So we decided to adopt the object, label it as collection and continue to follow and record the stories of the community that shares the van. This is how it became the first item in our active collection of the city:

16 As quoted from the Museum of Homelessness website. Available at https://museumofhomeless ness.org/about/ (accessed 1 April 2021).

17 Burón Díaz 2012. 
Real Rotterdam Heritage. [...] This new way of collecting is a sustainable and dynamic way of connecting the museum with urban communities. [...] Our key aim is to do this with Rotterdammers, and use their insights to build an active collection of the city that reflects contemporary issues and experiences." ${ }^{m 8}$

\section{References}

Bennett, Tony. 1995. The Birth of the Museum: History, Theory, Practice. London: Routledge.

Búron Díaz, Manuel. 2012. "Los Museos Comunitarios Mexicanos en el Proceso de Renovación Museológica." Revista de Indias 72.254: 177-212.

de Varine, Hugues. 1978. "L'Écomusée." Gazette 11.2: 28-40.

Findlen, Paula. 1989. "The Museum: Its Classical Etymology and Renaissance Genealogy." Journal of the History of Collections 1.1: 59-78.

Fouseki, Kalliopi. 2010. “'Community Voices, Curatorial Choices': Community Consultation for the 1807 Exhibitions." Museum and Society 8.3: 180-192.

Hoff, Kenny. 2015. "1/6 GLOW: A Festival of Fire \& Light Santa Cruz 10/16/2015." YouTube [video], 21 October 2015. Available at https://www.youtube.com/ watch?v=ZoSq71FCRiQ (accessed 1 April 2021).

Kassim, Sumaya. 2017. "The Museum Will Not Be Decolonised." Media Diversified [essay], ${ }_{5}$ November 2017. Available at https://mediadiversified.org/2017/11/15/ the-museum-will-not-be-decolonised/ (accessed 1 April 2021).

Kreps, Christina. 2011. "Non-Western Models of Museums and Curation in Crosscultural Perspective." In Sharon Macdonald, ed. A Companion to Museum Studies. Malden and Oxford: Wiley-Blackwell. 457-472.

Riva, Raffaella, ed. 2017. Ecomuseums and Cultural Landscapes: State of the Art and Future Prospects. Santarcangelo di Romagna: Maggioli Editore.

Santa Cruz MAH. 2013. "GLOW: A Festival of Fire and Light 2013." Vimeo [video], 23 November 2013. Available at https://vimeo.com/80158912 (accessed 1 April 2021).

Simon, Nina. 2010. The Participatory Museum. Santa Cruz: Museum 2.0.

Simon, Nina. 2013. "Quick Hit: Long Story about the MAH." Museum 2.o [blog], 20 March 2013. Available at http://museumtwo.blogspot.com/2013/o3/quickhit-long-story-about-mah.html (accessed 1 April 2021).

Simon, Nina. 2016. The Art of Relevance. Santa Cruz: Museum 2.o.

18 As quoted from the Museum Rotterdam website. Available at https://museumrotterdam. nl/en/echt-rotterdams-erfgoed (accessed 1 April 2021). 


\title{
$3 \quad$ Decentering
}

\author{
Csilla E. Ariese
}

\begin{abstract}
Museums tend to operate according to prevailing norms. Shifting their narratives or processes requires stepping away from these norms. Such decentering is uncomfortable, it is a change that is necessarily destabilizing. It requires either deep self-reflection or other/external voices to realize that an alternative mode of operation is even possible or desired. It can be a painful process which will be welcomed by some and rejected by others. As such, decentering is a balancing act which requires careful consideration beforehand. Whether it is replacing a previously commonly used term, changing the order of a narrative, or subverting other expectations, decentering is hard work.
\end{abstract}

Keywords: alternative narratives, denormalization, undermining expectations, shifting norms

Decentering is essentially an act of shifting the norm.

\section{The challenge}

As human beings, we become used to things being a certain way, observing a specific order, following a particular path. Sometimes we may not even consider why we do things in those ways - it just feels 'normal.' We begin the alphabet with A, we start the new year on 1 January. Generally, these habits or customs are formed on the basis of aspects of our identities. Of course, I know that there are many languages that use a different script, and there are plenty of religions and cultures where the new year does not begin on that date. Yet, from my own bubble, my order seems 'normal.'

Ariese, Csilla E., and Magdalena Wróblewska, Practicing Decoloniality in Museums: A Guide with Global Examples. Amsterdam, Amsterdam University Press 2022 DOI: $10.5117 / 9789463726962 \_C H O 3$ 
Museums have also operated according to prevailing norms, for instance in how they order exhibitions. During the era of rampant archaeological expeditions and within the mindset of so-called 'cultural evolution,' it made sense for Western museums to lay out collected spear heads or axes from least to most 'sophisticated' cultures. Later, focusing more on the unfolding of history, they arranged their exhibitions chronologically. Now, it is increasingly common to find thematic orderings in exhibitions.

Norms, or thinking according to the currently controlling perspective, naturally has its issues. It becomes easier to overlook, often unthinkingly, the possibility of alternative viewpoints or approaches. For an example, let's turn to the Caribbean, a region that was settled by Indigenous peoples known now as Amerindians thousands of years ago. From the late 15 th century onwards, the area was colonized and forcibly conquered by several European powers and parts of the Caribbean are still under foreign dominion. Despite the region's long indigenous history, Caribbean museum narratives still sometimes begin with 1492 as their chronological starting date, either briefly discussing Indigenous peoples later, or not including them at all. From a colonizer's perspective, Caribbean history 'began' with the devastating arrival of Columbus and his companions. Instead, beginning the narrative earlier or referring to the region's islands by their indigenous names first are examples of how decentering can be achieved. As a result, these changes can shift how visitors and inhabitants view their history and their identity, as well as move the norm.

Decentering is uncomfortable. It can feel like an earthquake at the base of your identity. It can make certain people become extremely defensive about their traditions and customs. Especially for the controlling group, for whom the norm feels normal, decentering may feel like a deliberate attack. Yet, if the point of decentering is to shift the norm, the hope is that perhaps some others might now feel more included in the norm. It will help to improve and increase the representation of them and their perspectives.

The question here is which narratives, perspectives, norms your museum wants to cement and strengthen. If certain visitor groups could become alienated by an act of decentering, is this in line with the (new) mission of the museum or not? If they choose to no longer visit your institution, but you attract new visitor groups, is that desirable?

\section{The change}

As with all change, decentering is a balancing act which requires careful consideration beforehand in order to identify why you wish to decenter and 
to which extent. It is a challenging exercise because it requires the whole team to let go of their habits and try to recalibrate their thinking and their practices. Intentions to decenter may not always be successful if there is not enough input from people who have different perspectives and can help step beyond the norm. Or if these people's input is ignored.

An example of an exhibition that intended to decenter, but nonetheless ended up falling short, was Reimagining Captain Cook: Pacific Perspectives at the British Museum (2018-2019). . The exhibition was intended, as was clear in its title and introductory panel text, to 'reimagine' Cook and it suggested to do so based on Pacific perspectives. Although the BM could have decentered their narrative, the team fell into their Western habits in ordering the exhibition, designing the exhibition space, and writing the texts. The anteroom, the exhibition's prologue, consists of official accounts of Cook's journey. Many of the subsequent panel texts continue this trend of Cook first, Pacific perspective second: the first sentence, or even the first word, was Cook's name, only afterwards juxtaposed with words (paraphrased or quoted) from Pacific artists or others. The frequent pairing of 'technically advanced' navigational tools or cartographic maps with 'subjective' objects such as Pacific artworks or performances, strengthened stereotypical dichotomies of exoticism: topographic/experiential and objective/subjective. ${ }^{2}$ As a reviewer noted, "ultimately, artworks are enlisted to legitimise, rather than destabilise, the authority of Western visitors."

In the above example, the exhibition was not shocking or surprising to Western visitors, as their perspectives and stereotypes were not truly confronted. Had the exhibition succeeded in decentering, for instance by really flipping the narrative and taking Pacific perspectives as the start and end points for all aspects of the exhibition, Western visitors would have been more unraveled. When your expected pattern or habit is disrupted, that is when you can consciously consider both the norm and why it is being shifted.

Decentering is an act of undermining typical expectations - leading to a positive change for those who have felt excluded from the norm and hopefully also positive effects for those who can appreciate more people feeling included in the norm. Language can be a powerful tool in decentering. The urge to change terminology related to slavery - for example, using the term 'enslaved person' instead of 'slave' - is an important example from recent years. The former indicates the active act of enslavement and shows directly

1 For a critical review, see Andrew Stooke (2019).

2 Said [1978] 2003.

3 Stooke 2019: 2. 
that other persons were responsible for someone's enslavement. It steps away from the passive victimhood connotated in the term 'slave' and reveals not only the fault of another, but also the resilience of the enslaved person.

Decentering is hard work, even if it 'just' concerns changing one term throughout the museum. It requires carving out a new path and the process is likely to be confrontational for both the museum's staff and the visitors - new and old. As an example, we might consider when the Amsterdam Museum decided to no longer use the term 'Golden Age' as synonym for the Dutch 17 th century. ${ }^{4}$ Thus, the choice to engage in decentering should be thoroughly considered and fully supported by the institution and their communities. To ensure success, it requires that people with the desired perspective are involved in meaningful ways, so as to avoid unwittingly falling back into old habits.

\section{Memento Park | Budapest, Hungary}

Memento Park, known in Hungarian simply as the Statue Park, is an open-air museum on the outskirts of Budapest and was opened to the public in 1993. The museum contains two parts: the open-air statue park, designed by architect Ákos Eleőd, and a square in front of the park entrance where an exhibition space is housed in a simple barracks structure.

The statue park is designed to be aesthetically simple and to provide an almost 'neutral' setting. It consists of three adjacent figure-eight-shaped paths, along which in total there are 42 statues and memorial plaques. All of these sculptures are from Hungary's communist period (1949-1989) and were removed more or less immediately following Hungary's independence. Memento Park embodies decentering literally: the statues and plaques have been removed from their original locations and placed in a new setting. This act of removal offers a significant recontextualization of these communist statues.

Many of the statues were previously located in prominent places in Budapest and elsewhere in Hungary, for instance on major squares or on Gellért Hill, which overlooks Budapest's castle and the Danube. Their massive sizes and heroic poses gained power in these important, highly visible locations. However, taken into the statue park, where these same sculptures are placed along a simple gravel path without any embellishment or pomp, their power diminishes. They have been relegated to the outskirts and stand together in what used to be a field. They are so clearly out of place, so obviously uncomfortable like fish out of water, that they become hollow 
Figure 3.1 The decentered giant charging sailor, Republic of Councils Monument

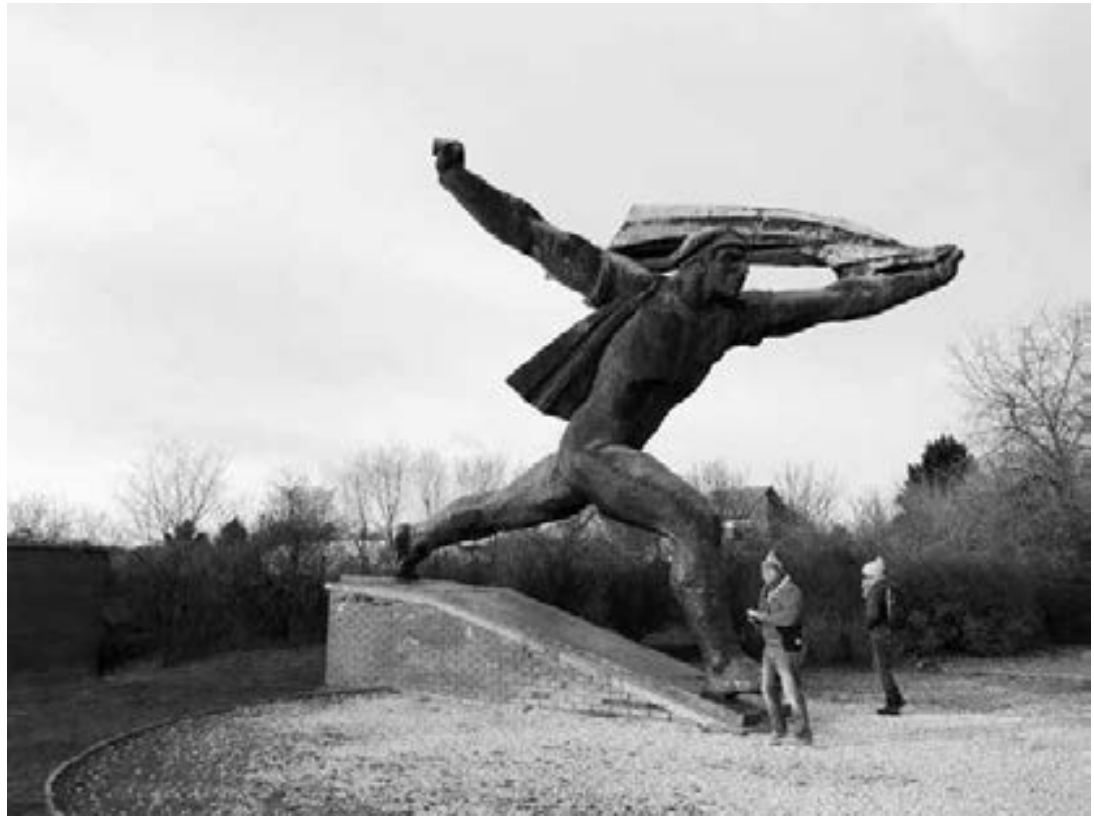

Memento Park; sculpture by István Kiss, 1969; ${ }^{6}$ photo by Csilla E. Ariese, 2019

shells of themselves. Interestingly, when I visited Memento Park with my Hungarian relatives, they commented how much they used to hate certain statues that they encountered regularly in the city, but that they actually look less ugly in their current location.

In the words of Eleőd, Memento Park is about democracy: "after all, only democracy can provide the opportunity for us to think freely about dictatorship." From my own visits with my family, this was also clear. Walking around the park offered opportunities for them to recall life during the communist period, the brutality of the regime, and its propaganda of life in the West. Memories and thoughts that could only surface in this context where dictatorship had been decentered.

5 As quoted from the Memento Park website. Available at https://www.mementopark.hu/en/ concept/commendation/ (accessed 1 April 2021).

6 This statue was originally located on the Parade Ground (Felvonulási tér), across from a massive Stalin statue. The Parade Ground has since been renamed to the Fifty-sixers Square (Ötvenhatosok tere) in honor of the 1956 revolution. 
As a final point, the exhibition space contains a chronological history of Hungary's communist period, revolution, and the fall of communism. Here, we also find a looped video called The Life of an Agent. It is a montage made in 2004 and contains film fragments produced by the Ministry of Interior Affairs between 1958-1988. The films were intended to provide training and instruction to secret police agents and show, among others, how to search a house, how to plant a bug, or how to tail a suspect. In the setting of the Memento Park museum barrack and its small theater with plush cinema seating, this film with its clumsy acting appears satirical. It is so out of place that it becomes comedic, while of course the historical reality of the Hungarian communist regime and its secret agents was all but comical. After watching this film, my grandmother recalled a personal history. One of my grandfather's closest friends and colleagues operated as a secret agent and it was understood that when they travelled abroad together for scientific conferences, he was there to spy on my grandfather. This story brought home how severe the system of control and surveillance was during that time and illustrates how well the secret agent training films are decentered in Memento Park.

\section{Dress Code: Are You Playing Fashion? | National Museum of Modern Art | Kyoto, Japan}

First established in 1963 as an annex of the National Museum of Modern Art in Tokyo, Kyoto's National Museum of Modern Art (MoMAK) was reopened in its new building in 1986. As a national institution, it collects and preserves artworks of 2oth-century Japan and other parts of the world, with a focus on artists and artistic movements from Kyoto and the Kansai area. Its collection emphasizes nihonga (Japanese-style paintings) and crafts. The artworks displayed in its 'permanent' exhibition, the Collection Gallery, are rotated about five times a year, ensuring that the majority of the collection is taken out of storage for display.

To coincide with the International Council of Museums' Triennial Conference in September 2019, MoMAK together with the Kyoto Costume Institute and the Contemporary Art Museum, Kumamoto, presented the exhibition Dress Code: Are You Playing Fashion? The exhibition aimed to question the dress codes that "are associated with the cultures and customs of different periods, regions, and social classes." It contained about 90 objects from the

7 Introductory wall label, Dress Code: Are You Playing Fashion?, National Museum of Modern Art, Kyoto (as seen in 2019). 
Figure 3.2 Juxtaposing costumes and contemporary art to question whether fashion requires cultural literacy. Dress Code: Are You Playing Fashion?

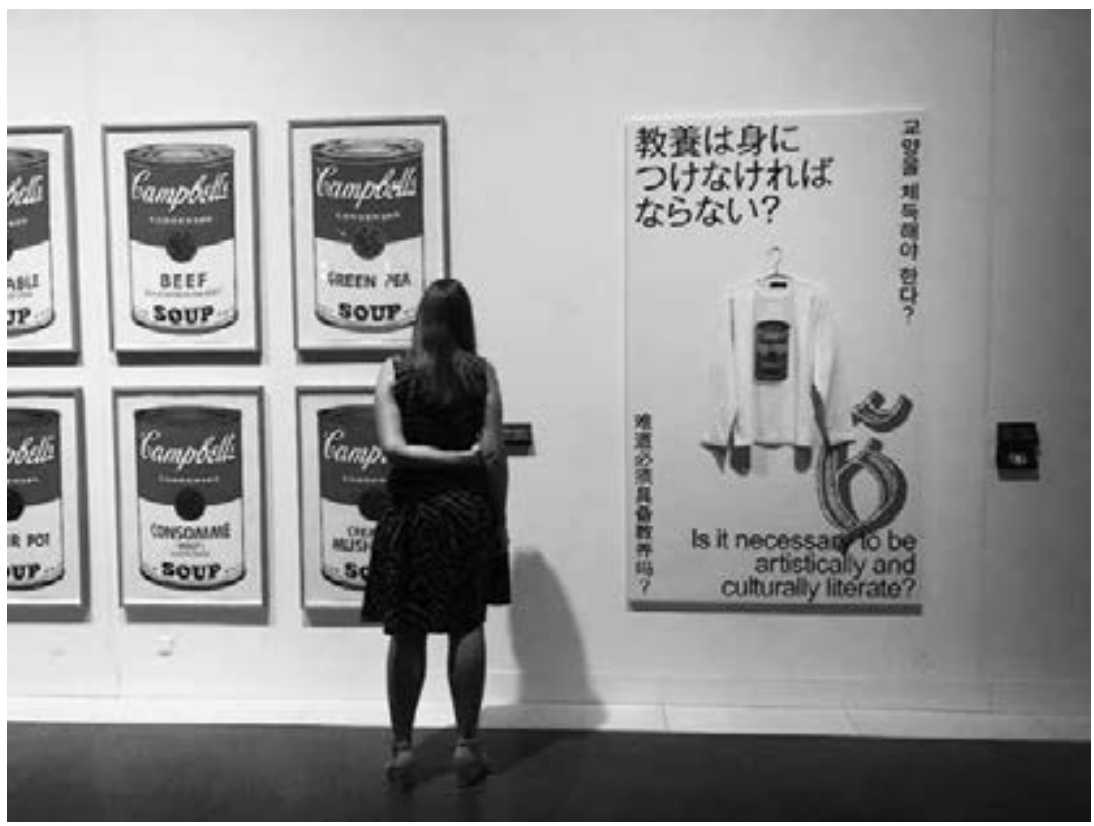

National Museum of Modern Art, Kyoto; photo by Csilla E. Ariese, 2019

collections of the Kyoto Costume Institute, from 18th-century court dress to contemporary street wear.

Divided into 10 parts, each section was headed by a critical question. Directed at the audience, these questions were often jarring, intended to make you critically rethink your own dress codes and your perceptions. Questions such as: Is it necessary to fight to survive? Is it necessary to be artistically and culturally literate? Do you have to intentionally choose your clothes? The extensive label texts and the accompanying displays of both artworks and costumes, dove deeper into each question. For instance, they showed how military uniforms have inspired fashion trends that mimic military prints and styles, changing perceptions of the military and warfare. Yet these fashion trends also play with notions of camo, pushing camo towards pixel art. Another panel illustrated how specific colors of dress have been used in protest movements (\#MeToo and \#BlackLivesMatter) or to show solidarity with communities such as the LGBTIQA+ community (Wear It Purple Day).

The exhibition decentered on two levels. Firstly, it decentered the collection of the Kyoto Costume Institute by juxtaposing its costumes with 
MoMAK's collections of contemporary media and artworks. This decentering of the two collections was aided by the in-depth, critically reflective panel texts. Secondly, the exhibition aimed to decenter the perceptions and notions of its visitors, encouraging visitors to reflect on their own dress codes and how they perceived themselves and others based on clothing. Many of the labels spoke directly to the visitor, disrupting the perhaps casual way they chose their outfit of the day.

\section{Spitzmaus Mummy in a Coffin and Other Treasures | Kunsthistorisches Museum | Vienna, Austria}

Vienna's Kunsthistorisches Museum (KHM) was opened in 1891 at the same time as the Naturhistorisches Museum Wien. The two museums sit across from each other and are designed according to the same architectural plan (mirrored). The primary intent of the two museums was to house and display the imperial collections, dividing them into art history and natural history. The KHM is especially known for its Picture Gallery, but also contains collections of Egyptian, Roman, and Greek antiquities, a coin cabinet, as well as arms and armor collections and ancient musical instruments. The collections of the Weltmuseum Wien, the Austrian Theatermuseum, and several castles also fall under the KHM. As a result, the more than 4 million objects held by the KHM in 14 historical collections are incredibly diverse and many have not recently or ever been on public display.

In 1969-1970, a travelling exhibition in the USA caused a stir that is still discussed in museums today: Andy Warhol's provocative and unconventional selection of objects and methods of presentation for Raid the Icebox 1 with Andy Warhol. The project sought to revisit and bring to light the Rhode Island School of Design Museum of Art's storages by having a contemporary artist be in charge. Inspired by this project, the KHM developed a program of artist-curated exhibitions. The program was set up by KHM curator Jasper Sharp and was inaugurated in 2012. For its third installment, Sharp invited filmmaker Wes Anderson and illustrator and author Juman Malouf. The resulting exhibition, Spitzmaus Mummy in a Coffin and Other Treasures, opened at the KHM in 2018. ${ }^{8}$

Spitzmaus... was a clear act of decentering. Both its curatorial process and the resulting exhibition vastly undermined the typical expectations of museum staff and visitors. Let's begin with the process. Anderson and Malouf were given free rein to explore the collections of the KHM and 
Figure 3.3 A vitrine organized by color had conservators reconsider how to display objects together that require different climates

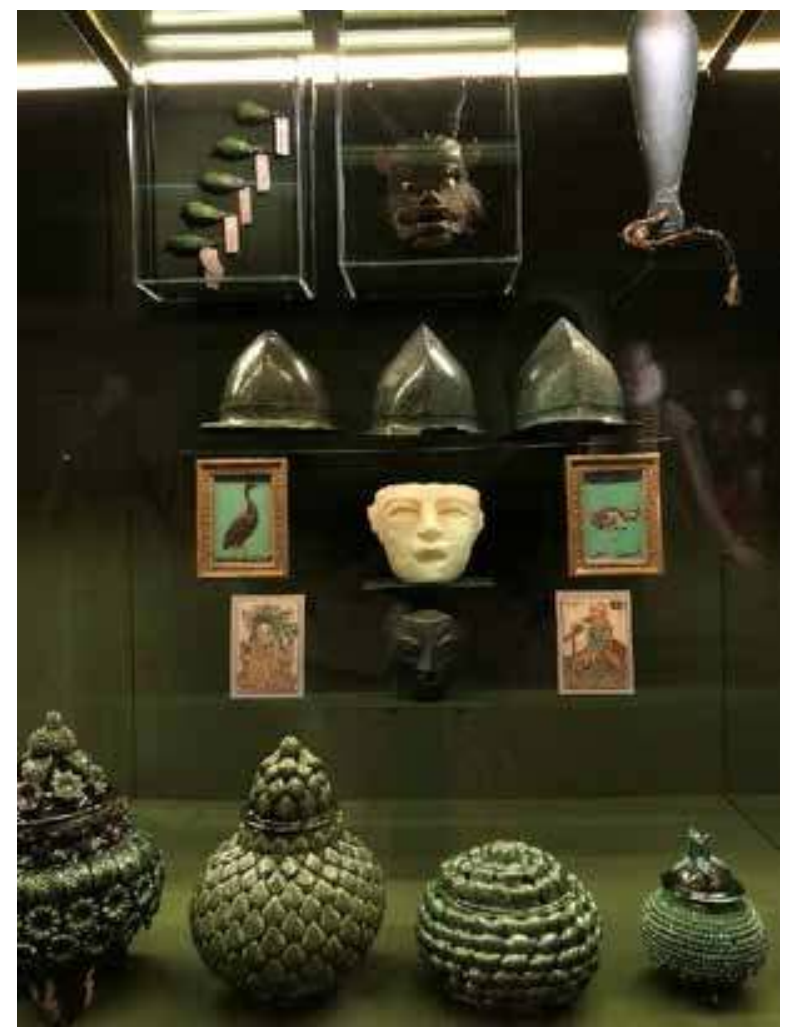

Kunsthistorisches Museum; photo by Csilla E. Ariese, 2019

to select objects that they wished to include in the exhibition. Curators, conservation staff, and others had to radically rethink their processes. For instance: how to find objects in a specific shade of green when the collection databases do not have color as a search category? How to deal with placing items with vastly different climate control needs in the same display case? How to exhibit an empty historical display case? Of the 423 individual objects selected for the exhibition, $35^{\circ}$ had to be taken out of storage, some needed additional conservation or restoration, and others required first-of-a-kind insurance so that they could be moved to the KHM. In the audio tour of the exhibition, Anderson, Malouf, and Sharp discuss some of the challenges of their process. Staff members struggled - but also critically rethought their standard processes and practices: why did they do certain things in certain ways? 
The exhibition was also decentering to visitors as it did not align with their usual experiences of museum visiting. Beyond an introductory panel outside the gallery, the exhibition space contained no written labels. A booklet containing object descriptions could be borrowed, but visitors had to find out for themselves what the connections between objects were and how the objects in the eight 'rooms' were tied together: for example, green objects, miniatures, wooden objects, or boxes and cases. Anderson and Malouf selected objects intuitively, as Sharp recalls in the audio tour, "it was all about the sound and shape of the word [Spitzmaus], which actually is exactly how he's curated the whole exhibition: the sound and look and smell and shape of the thing rather than the individual significances." ${ }^{m}$ Reading visitor's reviews on TripAdvisor shows that some people found it liberating to explore the exhibition visually and to make their own interpretations of connections, while others found this task daunting and confusing. To Anderson and Malouf the links were obvious, but not only visitors needed time to decenter their expectations:

One of the Kunsthistorisches Museum's most senior curators (educated, of course, at the University of Heidelberg) at first failed to detect some of the, we thought, more blatant connections; and, even after we pointed most of them out, still questions their curatorial validity in, arguably, all instances. ${ }^{10}$

\section{Indigenous 'Museum-like' Centers | Canada \& USA}

Historically, Indigenous communities in Canada and the USA have had deeply negative experiences and relationships with museums. In part, this is due to the fact that many collectors and museums, particularly during the 19th and early 2oth centuries, exploited Native peoples, stole their material culture and human remains, and destroyed or seized their sites and lands. For another part, however, it is due to the fact that the concept of the museum does not easily fit into traditional American Indian practices. Karen Coody Cooper aptly illustrates that "the closest analogy to a museum in Native life is reverence for elders as holders of knowledge, but elders are not a place or a thing."'11 
During the first half of the 2oth century, Indigenous peoples in Canada and the USA were alienated from mainstream museums and carried resentment or anger towards institutions where they were not welcome and which were holding their objects in unethical ways. Together with the civil rights movement in the USA, Indigenous communities protested for their rights and some of these protests specifically targeted cultural rights and heritage. Over the following decades, these protests resulted in the passing of the Native American Graves Protection and Repatriation Act and the Indian Arts and Crafts Act (both in 1990) and the mandate for the National Museum of the American Indian (1989). NAGPRA in particular was vitally important for (recognized) Native communities to regain their ancestral human remains and sacred objects for reburial.

These changes, along with the New Museology movement, the development of the 'ecomuseum' concept ${ }^{12}$ and the changing perspectives of mainstream museums' staff on representation and participation, offered Indigenous communities new opportunities to engage with the concept of the museum and revisit their relationship with this contentious institution. On the one hand, Indigenous communities have chosen to develop their own museum-like institutions, and over 200 of these exist across Canada and the USA. ${ }^{3}$ Yet, in protest against the term:

Many Native museum-like facilities refuse to use the word museum in the name of their facility, and often their museum-like centers operate differently than museums have typically done. Native communities often develop people's centers, history centers, friendship centers, or cultural centers, and sometimes these places are like museums. ${ }^{14}$

In these centers, we see alternative practices. Objects are considered living and kept as such, sometimes in places where smudging practices can occur. Other centers dismiss the notion that museums should be founded on vast physical collections, focusing instead on oral histories, reconstructions, and intangible heritages. In the case of the Makah Cultural and Research Center, objects recovered from the Ozette village site were separated into men's work materials and women's work materials, and staff organized their collection by Makah cognitive categories. ${ }^{15}$ And when the Ak-Chin 
developed an exhibition space within their community center, they travelled to many other museums and museum-like institutions to develop their own plans for what became an ecomuseum. ${ }^{16}$ Finally, the exhibition Fluffs and Feathers: An Exhibit on the Symbols of Indianness (Woodland Cultural Centre, Brantford, Ontario, 1988) specifically treated stereotypes about American Indians, in part that which occurs in museums. ${ }^{17}$

By protesting the very name of the museum institution, and many of its associated (harmful, unethical) terms, policies, practices, and stereotypes, Indigenous communities have managed to indigenize the institution known as 'museum.' This indigenization has also had its effect on other museum institutions. The repatriation of objects and human remains has continued to take place. Additionally, some curatorial practices of the National Museum of the American Indian - many of which were originally devalued by established museum practitioners - have since inspired exhibitions and practices elsewhere. ${ }^{18}$ As such, the Indigenous museum-like centers in Canada and the USA have indigenized and decentered the very concept of the museum institution.

\section{Further reading}

Derelict Shards: The Roaming of Colonial Phantoms | Yvonne Adhiambo Owuor 2020

Potential History: Unlearning Imperialism | Ariella Aïsha Azoulay | 2019 Re-collecting and Re-allocation: Collection Assessment, Ethical Deaccessioning and Multiple Stakeholders | edited by Wayne Modest, Robin Lelijveld, and Ninja Rijnks-Kleikamp | 2020

\section{Further examples}

\section{Museo Memorial de la Resistencia Dominicana}

Santo Domingo, Dominican Republic (opened 2011)

"In the Dominican Republic there are several museums on history, geography and other subjects. However, there was no museum dedicated to the memory of the victims of state terrorism. This museum seeks to rescue 
and preserve the historical memory of the Dominicans. Its mission is to promote with historical significance and citizen awareness the struggles of several generations of Dominicans during the dictatorship of Rafael Leonidas Trujillo Molina, its antecedents and consequences." ${ }^{19}$

\section{The Museum of Innocence}

Istanbul, Turkey (opened 2012)

"The Museum of Innocence is both a novel by Orhan Pamuk and a museum he has set up. From the very beginnings of the project, since the 1990s, Pamuk has conceived of the novel and museum together. The novel, which is about love, is set between 1974 and the early'oos, and describes life in Istanbul between $195^{\circ}$ and 2000 through memories and flashbacks centered around two families - one wealthy, the other lower middle class. The museum presents what the novel's characters used, wore, heard, saw, collected and dreamed of, all meticulously arranged in boxes and display cabinets. It is not essential to have read the book in order to enjoy the museum, just as it is not necessary to have visited the museum in order to fully enjoy the book. But those who have read the novel will better grasp the many connotations of the museum, and those who have visited the museum will discover many nuances they had missed when reading the book." ${ }^{20}$

\section{WAG-Qaumajuq}

\section{Winnipeg, Canada (opened 2021)}

"Qaumajuq is an innovative new museum, home of the largest public collection of contemporary Inuit art in the world. [...] Qaumajuq is the name that Indigenous language keepers gave to the Inuit art centre. Inspired by the light-filled spaces of the new building, Qaumajuq (pronounced KOW-ma-yourk and sometimes heard HOW-ma-yourk) means "it is bright, it is lit" in Inuktitut. [...] Inuit have guided the creation of Qaumajuq and lead the development of programs that will connect you with others, such as the inaugural show INUA. The WAG partners with Inuit birthright organizations, governments, associations, and individuals across Inuit Nunangat and in urban and Southern communities to ensure Qaumajuq

19 As quoted from the Museo Memorial de la Resistencia Dominicana website (in Spanish, our translation). Available at http://www.museodelaresistencia.com/museo-memorial-de-laresistencia-dominicana/ (accessed 1 April 2021).

20 As quoted from the Museum of Innocence website. Available at https://en.masumiyetmuzesi. org/page/the-museum-of-innocence (accessed 1 April 2021). 
is a place where all Inuit feel welcome, engaged, and inspired to share their culture with the world. Creating spaces for Inuit elders to pass their teachings on to the broader community is critical to building bridges of understanding - between cultures, between North and South, and between generations." ${ }^{21}$

\section{References}

Anderson, Wes. 2018. "Introduction." In Wes Anderson and Juman Malouf, authors; Sabine Haag and Jasper Sharp, eds. Spitzmaus Mummy in a Coffin and Other Treasures. Köln: Verlag der Buchhandlung Walther König. 18-19.

Ariese, Csilla E. 2019. Decolonizing the Amsterdam Museum: A Work-in-Progress to Becoming a More Inclusive City Museum. ECHOES: European Colonial Heritage Modalities in Entangled Cities [Online]. Available at http://projectechoes.eu/ deliverables/ (accessed 1 April 2021).

Ariese, Csilla E., and Françozo, Mariana. 2019. "Completeness: How the Lack of a Mouse in a Box Revisits the Spectacle of the Kunstkammer." Curator 62.4: 649-656. DOI: doi.org/10.1111/cura.12317.

Azoulay, Ariella Aïsha. 2019. Potential History: Unlearning Imperialism. London: Verso.

Cooper, Karen Coody. 2008. Spirited Encounters: American Indians Protest Museum Policies and Practices. Lanham, MD; New York; Toronto; and Plymouth: Altamira Press.

Cooper, Karen Coody, and Sandoval, Nicolasa I. 2006. Living Homes for Cultural Expression: North American Native Perspectives on Creating Community Museums. Washington, D.C. and New York: Smithsonian Institution and National Museum of the American Indian.

de Varine, Hugues. 1978. "L’Écomusée." Gazette 11.2: 28-40.

Fuller, Nancy J. 1992. "The Museum as a Vehicle for Community Empowerment: The Ak-Chin Indian Community Ecomuseum Project." In Ivan Karp, Christine Mullen Kreamer, and Steven D. Lavine, eds. Museums and Communities: The Politics of Public Culture. Washington: Smithsonian Institution. 327-365.

Modest, Wayne; Lelijveld, Robin; and Rijnks-Kleikamp, Ninja. 2020. Re-collecting and Re-allocation: Collection Assessment, Ethical Deaccessioning and Multiple Stakeholders. Work in Progress series. Amersfoort: Tropenmuseum, Afrika Museum, Museum Volkenkunde and Wereldmuseum.

21 As quoted from the $W A G$ - Qaumajuq website. Available at https://www.wag.ca/qaumajuq/ (accessed 1 April 2021). 
Owuor, Yvonne Adhiambo. 2020. "Derelict Shards: The Roaming of Colonial Phantoms." CODESRIA Bulletin Online 10:1-10. Available at https://codesria.org/IMG/ pdf/10-_y_owuor_codbul_online_1_.pdf (accessed 1 April 2021).

Ronan, Kristine. 2014. "Native Empowerment, the New Museology, and the National Museum of the American Indian." Museum \& Society 12.1: 132-147.

Said, Edward W. [1978] 2003. Orientalism. London: Penguin Group.

Smith, Claire. 2005. "Decolonizing the Museum: The National Museum of the American Indian in Washington, D.C." Antiquity 79-304: 424-439.

Stooke, Andrew. 2019. "Captain Cook Reimagined from the British Museum's Point of View.” Third Text Online 1-12. Available at www.thirdtext.org/stooke-cookbritishmuseum (accessed 16 July 2021). 



\title{
4 Championing Empathy
}

\author{
Csilla E. Ariese
}

\begin{abstract}
Empathic behavior is all the more important in a globalizing world and to tackle the current problems facing our globe. Although emotions have not always been the strong suit of museums, in recent years emotive exhibitions have become more common, as well as creating space for emotional experiences, reflections, and social interactions. Museums are well-equipped to support championing empathy and to encourage empathic behavior among their visitors. They can challenge harmful stereotypes. Furthermore, empathy is also an important skill honed 'back stage' in museums, in terms of HR policies, equitable hiring, broad representation, and balanced management.
\end{abstract}

Keywords: emotive exhibitions, equity, staff representativity, challenging stereotypes

Empathy for other living beings is the key to better and more

generous behavior.

\section{The challenge}

Empathy is the ability to understand and share in the emotions of another being. Some people are naturally more empathic than others; learning to be (more) empathic is vitally important. In an increasingly populated and globalizing world, it is tempting to group humans and other living beings in big clusters of anonymity. Stereotyping is one way in which this is achieved: "men are bad at multi-tasking" or "cats are aloof and dogs are loving." Beyond being a source of error and (hurtful or harmful) discrimination, stereotyping also provides distance. Being able to dismiss a whole group of people due

Ariese, Csilla E., and Magdalena Wróblewska, Practicing Decoloniality in Museums: A Guide with Global Examples. Amsterdam, Amsterdam University Press 2022 DOI: $10.5117 / 9789463726962 \_C H O 4$ 
to some (perceived) quality allows for a false disconnect between yourself and them, effectively 'othering' them and making them unrelatable.

Yet, in a globalizing world, empathy for others, and particularly for those whom we might perceive to be 'different,' is all the more important to tackle the challenges of our era: the climate crisis, migration, pandemics, and so on. These challenges force us to work together globally and bring us into contact with other people around the world. If we are unable to feel empathy for others, we will be unable to work together or unwilling to help each other. Selfishness is the result of a lack of empathy.

Museums have a role to play in championing empathy when it comes to their staff, visitors, and partners. Yet if museums do not lead by example internally, the empathic tone of an exhibition or program may feel disingenuous or hypocritical - for instance, if the museum is very careful to use certain terminology to make a community feel respected, but then does not offer staff members from that community fair wages or the same respectful tone in the work environment. Championing empathy is a task that needs to be undertaken behind the scenes as well as in the public arena.

Over the last couple of decades, museums have become more familiar with emotive exhibitions which build on emotional storytelling devices. Such exhibitions may feature quotes or personal narratives, thus highlighting individual biographies rather than generalizing. Such techniques work because visitors can more easily connect to a named individual than to an anonymous group, and building empathy for such a non-anonymous person can in turn create empathy for the community they belong to. Personal narratives are relatable, and being able to relate to someone is an important step in coexisting and cooperating.

Museums have also been making use of more interactive displays (whether digital or analogue) and this creates opportunities for visitors to engage and interact with others - whether from the same visiting group or with strangers. At the Anne Frank House (starting in 2005) Free2Choose was an interactive display ${ }^{1}$ which showed a series of film clips on conflicting rights and freedoms guaranteed by law: what if neo-Nazis use the right to demonstrate in front of a synagogue on Sabbath? Visitors were prompted at the end of each clip with a question and a yes or no vote. The results of the current visitors' vote, plus the overall results from all past visitors, would be immediately shown and were used by museum educators to ignite deep, critical conversations. By tying into the biography of Anne Frank and tool. 
her family, visitors could relate to the issues more empathically as well as understand that not all questions have simple answers.

\section{The change}

Championing empathy is essentially an individual process, which might make it seem like institutions do not have a role to play in increasing empathy. Yet, as institutions which guide behavior, provide knowledge, and allow space for emotions, museums are well positioned to champion empathy.

Above, I have already mentioned two examples. Interactive displays create opportunities for interaction with others and can be suitable for practicing and nurturing empathy. Emotive exhibitions using devices such as personal narratives can encourage visitors to relate to other persons or communities. Another type of emotive exhibition, which creates opportunities for experiencing and processing deep feelings, can also spark empathy. For these kinds of exhibitions, it is crucial to provide space for visitors to process or to safely discuss with others what they are feeling and experiencing.

Yet championing empathy goes deeper than exhibition practices and displays. It begins with the institutional mission and vision and the way in which staff members are treated within the museum: fair hiring and equal wages, transparent HR policies, an atmosphere in which everyone feels that they are respected and in which all are treated with dignity. Ensuring that staff is representative of target audiences is currently high on the agenda of museums, but if this 'diversity' is not present on all levels of staff/management, representation is limited and tokenistic. Additionally, diversity training may be necessary to discuss safe work environments. Terminology, phrasings, tone of voice, and behavior can all be worked on to ensure respect and sensitivity between staff. A better awareness of internal shortcomings, and the hard work needed to improve empathy within the museum, will also aid museum staff in their interactions with visitors.

Empathy is a skill that can be honed through museum visiting. Museum educators, and not just those working with children and young adults, are already very knowledgeable about training empathy and have vast experience in providing activities or moderating discussions that can support empathy. Museum guides are trained to bring strangers closer together during the course of a tour, finding points from which they can relate to each other and develop empathy. Museum staff working in front of house positions are also very familiar with treating visitors respectfully. However, 
for all museum staff it will remain a skill to practice daily to retain empathy and step beyond the simple stereotyping of visitors into categories.

Exhibitions can transparently challenge harmful and hurtful stereotypes, for instance by condemning issues such as discrimination (whether sexism, racism, homophobia, islamophobia, etc.), or supporting human and equal rights issues. As institutions that are often still seen as authoritative and which are trusted providers of information, museums can be greatly influential if they speak out sincerely. If a museum's decision is seen as very bold, it could lead not only to empathy, but also to decentering of the norm.

Although becoming more empathic is a personal process and challenge, museums can certainly play a role - on the one hand, by leading by example with their internal communication, policies, and interactions; on the other hand, by supporting and encouraging empathy within and between visitors.

\section{National Museum of African American History and Culture | Washington, D.C., USA}

Part of the Smithsonian Institution, the National Museum of African American History and Culture (NMAAHC) was opened to the public in $2016 .{ }^{2}$ Its development had taken 100 years of campaigning, since the first attempt for the creation of the museum by African American civil war veterans in 1916. The museum is dedicated to the documentation of African American life, history, and culture. It positions itself as a museum that shares an American story for all Americans, through an African American lens.

The creation of the NMAAHC was unique in the sense that the museum had no collections when the institution was formally established in 2003 . The museum decided to completely develop its own collections, rather than to take over previously existing collections housed in other institutions. A large portion of the staff was tasked in various ways to collect objects for the museum - both in the USA and from African nations and cultures. By the time of opening, the collection contained 34,000 items.

The diversity and depth of the collection is reflected in the museum's 12 exhibitions, spread out over five floors. Some of these exhibitions celebrate African American achievements, for instance in the arts or sports, or explore different contemporary communities. The history galleries are profoundly emotional and political spaces, where histories of slavery, resilience, wars, civil rights movements, emancipation, and segregation are unpacked. The history galleries combine the long arc of history with personalized narratives 
Figure 4.1 Contemplative Court

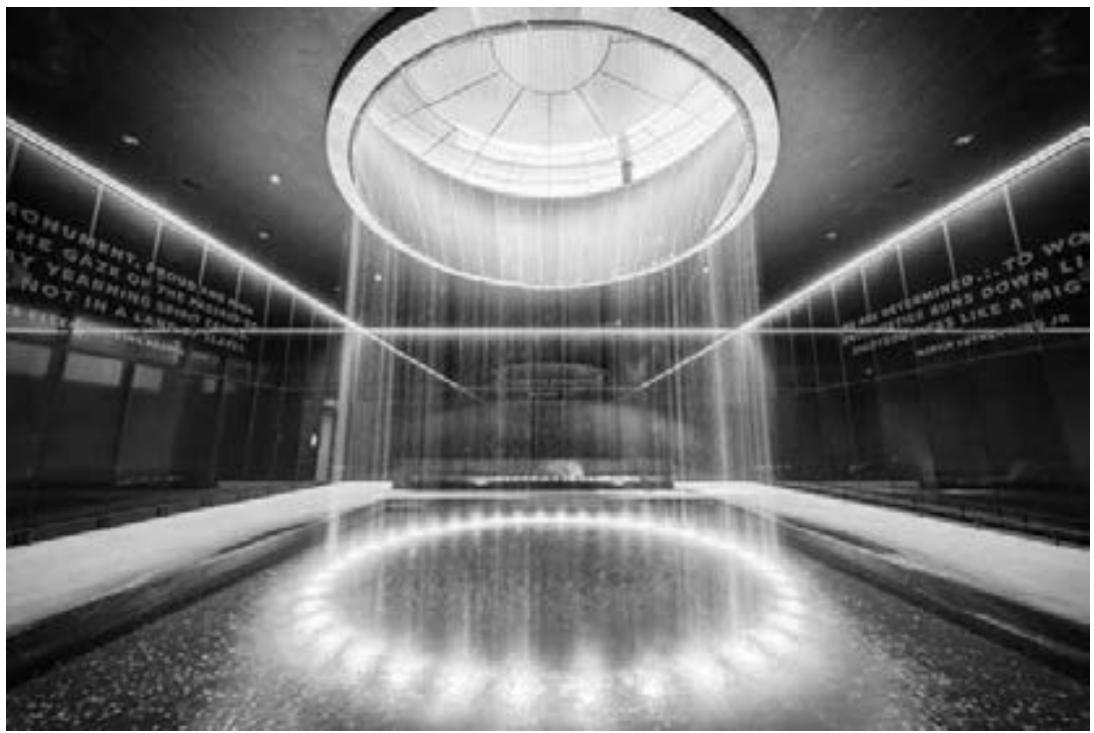

National Museum of African American History and Culture; photo by Jason Flakes

and associated donated or loaned objects, resulting in deeply emotive exhibitions. The personality and family history of each visitor will vastly impact how they experience the history galleries. Many visitors will have experienced a range of emotions by the time they exit the history galleries.

The design of the museum is perfectly suited for dealing with emotional, or emotionally drained, visitors. Following the history galleries is the Contemplative Court. ${ }^{3}$ A square room with bronze-colored walls is lit up by a giant round skylight. From the edges of the skylight, a circular waterfall drips down into a large square fountain. Visitors can sit here, look at the water and the light, listen to the sound of the fountain, and reflect upon empowering quotes by Martin Luther King Jr., Nelson Mandela, Frances Ellen Watkins Harper, and Sam Cooke. It is intended to be a space for pure emotion: for grief, for reflection, for resilience, for relief, for respite, and for release. Here, visitors know that they can cry, sing, or sit in silence freely and for as long as they wish.

The design of the NMAAHC shows deep empathy with its visitors. The Contemplative Court is given a central place and a space of importance. It catches and embraces visitors after they have journeyed through the history 
exhibitions whose route is over a mile long. This large space for emotion plays a significant role in the visitors' experience of the exhibition route and is more powerful than a small reflective nook or a seat to rest weary legs in a crowded exhibition hall. It is similar to reflective spaces in memorial museums, such as Holocaust museums or war memorials, but its moving water adds a spiritual and cleansing dimension. It helps visitors process historical grief before walking on to celebrate the contemporary.

\section{Museo Tula | Lagun, Curaçao}

Museo Tula (MT) was founded in 2007 and sits towards the Northwestern point of the Caribbean island of Curaçao. It is located on a former plantation estate and the main museum building is in the former great house (landhuis). The estate buildings were renovated for the purpose of the museum, whereas the lands of the estate are minimally maintained. The grounds along the rugged coastline are incorporated as a natural resource and a visit to the museum can be combined with an extensive walking tour through the gardens and wider landscape. The estate as a whole forms an ecomuseum. ${ }^{4}$

The mission of MT is to represent the local Afro-Caribbean community and this community is both its main target audience and its staff. In part, the museum focuses on Tula's uprising (1795) and other local revolts by enslaved persons. Other parts of the museum are dedicated to various aspects of Afro-Caribbean heritage, whether before or after emancipation: music, food, midwifery, clothing, and rituals surrounding birth and death. Throughout all of the museum, the underlying theme is resilience and resistance. For instance, musical instruments are paired with engravings showing celebrating, dancing enslaved persons and Dutch colonial proclamations forbidding the playing of drums or dancing among the enslaved.

Especially within this former plantation estate, MT undertakes strong acts of decolonization. Afro-Caribbean community members work here as tour guides to tell Tula's history and the history of their community from their own perspectives. 5 They are able to bring in personal histories to their tours. These community members are also vital for infusing the museum with intangible heritages. Some are hired to work in the museum's kitchen to prepare Afro-Caribbean meals and snacks; visitors can choose to add a warm lunch to their museum visit when they purchase their entrance ticket. 
Figure 4.2 The display on Afro-Caribbean literature includes a Papiamentu poem by Pierre Lauffer, beginning with the lines "Papiamentu indominable I Lenga di mi mama"

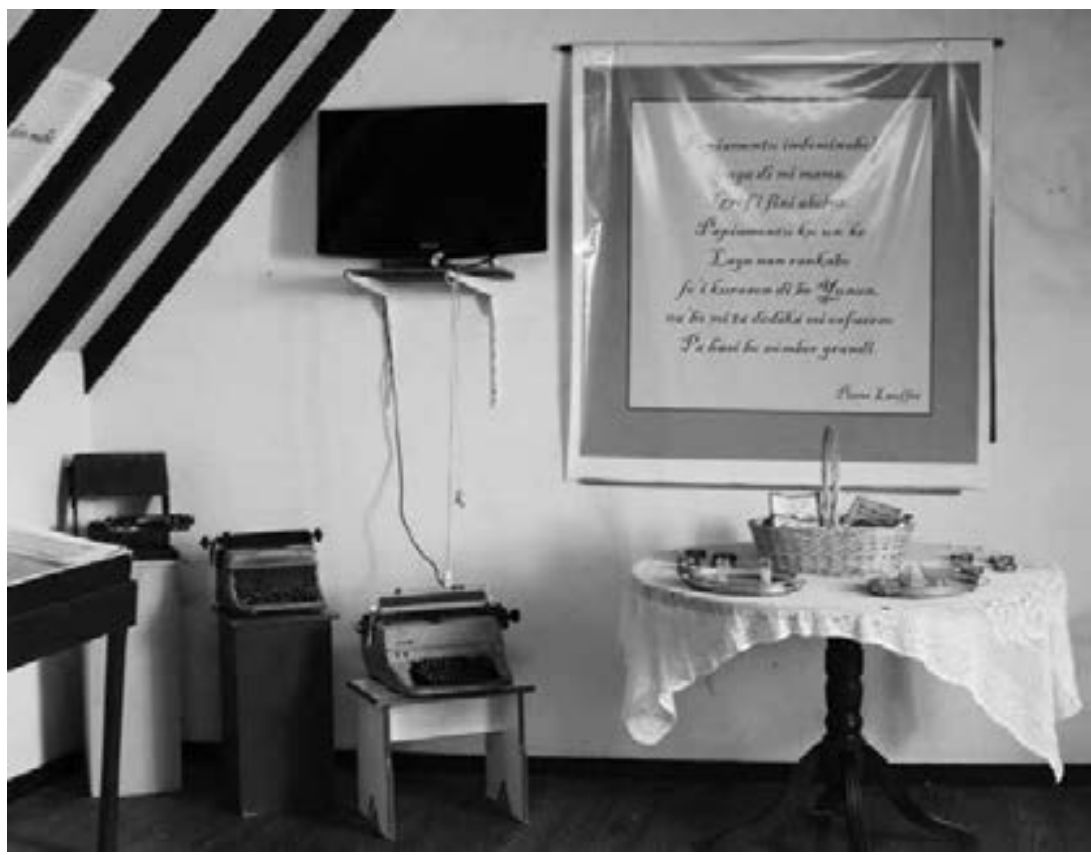

Museo Tula; photo by Csilla E. Ariese, 2014

Thus, the formerly colonized have retaken the entire plantation estate with their own cultural heritage: music, food, performances, histories, and objects.

An important aspect of MT's decolonization has been language. Indeed, the historical roots of post-colonial theories were in the field of literature. Furthermore, the field of decolonization has been impacted by the influential work by writer Ngũgĩ wa Thiong'o titled Decolonising the Mind. ${ }^{6}$ Language, he argues, is both a means of communication and a carrier of culture. It defines us and others, it transmits images of the world and reality. Essentially, the language we use shapes our culture, our identities, and how we see and understand the world around us. As such, the choice of language(s) used in a museum is far from a neutral decision.

Museo Tula uses Papiamentu as its main language throughout the museum and its exhibitions. Papiamentu is a creole language which probably developed around the $17^{\text {th }}$ century. At its roots, it is a mixture of Portuguese 
Figure 4.3 Decolonize language

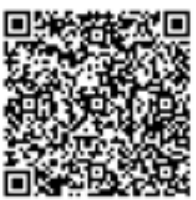

Artwork by Elwing Sương Gonzalez aka @elwingbling, 14 July 2020

and West African, with later influences from Dutch, English, and Spanish. It is presumed that the language was developed by enslaved persons working on plantations in Curaçao as a means of communication. It was also used by Sephardic Jewish colonizers, resulting in some of the earliest written documents in Papiamentu. Despite the Dutch colonizers' introduction of Dutch language education, thanks to strong and continued resilience, Papiamentu remained the main (spoken) language. After centuries of attempts to 'eradicate' this creole language by the colonizers, it was finally recognized as an official language in 2007.7 Museo Tula's decision to use Papiamentu as its main language is a decolonial act which shows empathy for a community whose language has been repressed for centuries. It allows that community to feel at home in the museum.

\section{POLIN Museum of the History of Polish Jews | Warsaw, Poland}

Set on the site of the former Jewish Ghetto of Warsaw, the POLINMuseum of the History of Polish Jews (POLIN) was opened to the public in 2013. The museum is run through a public-private partnership between the Association of the Jewish Historical Institute, the city of Warsaw, and the Ministry of Culture and National Heritage. In recent years, this partnership has revealed political clashes, particularly in appointing new directors of the museum.

The aim of the museum is to show the 1,000-year history of Jewish life in Poland, demonstrating on the one hand that Polish history is Jewish history, and on the other hand that Jewish history is Polish history. The museum promotes "the ideas of openness, tolerance and truth" and is a place for dialogue for "those who are ready to face the stereotypes and oppose xenophobia and nationalistic prejudices that threaten today's societies."

7 Papiamento was previously recognized in Aruba in 2003.

8 As quoted from the POLIN Museum website. Available at https://www.polin.pl/en/aboutmuseum (accessed 1 April 2021). 
While the museum focuses on the culture and history of a religious community, it is in many ways overtly political. For instance, its temporary exhibition Estranged:March '68 and Its Aftermath (2018) presented slogans from the anti-Semitic campaign of ' 68 together with quotes by contemporary Polish political leaders - resulting in a conflict between the museum and politicians in the media. In today's political landscape in Poland, the museum frequently finds itself having to fight for its mission to promote tolerance.

A significant amount of the museum's visitors come from abroad. In part, these are Jewish visitors whose family histories are related to the Warsaw Ghetto, or Polish Jews who have (been forced to) emigrated. The museum, and the memorial commemorating the Warsaw Ghetto Uprising of 1943 just outside, have become a site of pilgrimage.

The core exhibition is roughly chronologically structured and narratively follows 1,000 years of Jewish life, beginning with the first Jewish settlers in Poland in the 1oth century. Many of these early galleries contain replicas and aim to show traditional cultures, constructions, and ways of life. They also tell family biographies. Emotionally, the most affective galleries are those dedicated to the Holocaust and the Postwar Years, including pogroms and large-scale emigration due to a state-sponsored anti-Semitic campaign.

In the Holocaust gallery, many exhibition design techniques are used to ensure that the content of the exhibition is emotionally powerful and effective. For instance, the gallery is designed with a footbridge between two sets of stairs, overlooking a vibrant street. This design mimics the layout of the Warsaw Ghetto with a footbridge over Chłodna Street (an Aryan street) dividing the small and large Ghettos. Photographs of this footbridge have become iconic symbols of the Holocaust in occupied Poland. Furthermore, the exhibition contains many moving images, such as videos of life in the Ghetto, and audio fragments, which are particularly powerful tools for conveying personal stories. Quotes - both from survivors and those who perished or were murdered - provide strong emotional insights into life in the Ghetto. A long wall with endlessly many chalked numbers representing the people deported per day (July-September 1942) brings home the incomprehensible loss of life together with hastily written notes to neighbors or family members.

The core exhibition abounds in photographs. Yet, with very few exceptions, there are no photographs of dead persons. Only a few photos are shown in which the dead are entirely anonymous and their heads and faces are not visible. As a curator of POLIN explained, this was a deliberate act of empathy: "it is not that we do not want people [visitors] to feel hurt. We do 
not want to humiliate victims again." ${ }^{2}$ Thus, the core exhibition succeeds to be highly emotive - and to offer visitors the space to deal with these emotions - but also manages to leave victims' dignity intact.

\section{Tate Modern | London, UK}

The Tate Modern is one of four Tate museums, sharing a collection of nearly 70,000 artworks. The other three sites are Tate Britain, Tate Liverpool, and Tate St Ives. The collections are partially British art from 1500 until today and partially international modern and contemporary art. The first Tate museum opened to the public in 1897. Tate Modern focuses on international modern and contemporary art and was opened in 2000. It is housed in a former power station, whose unique architecture - and especially its famous turbine hall - impact the visiting experience and the possibilities for exhibitions and programs. The turbine hall is used for large-scale art installations, but also provides a grand open space for school groups to engage in activities or lunch in parallel. The exhibitions, located over several floors in two connected towers, encourage visitors to pick and choose which exhibitions to visit without a set path.

As with other national galleries and museums in the UK, Tate Modern charges no admission fee for its permanent exhibitions. It is vastly popular, attracting roughly 6 million visitors annually. Naturally, these visitors do not all share the same pre-existing knowledge of contemporary art. While some may be highly knowledgeable in the field and very familiar with how to 'read' contemporary art exhibitions, for others it might be their first time in such a museum. Art museums, with their white cube aesthetic and often minimal object descriptions, can be particularly daunting for inexperienced visitors. What should they be looking at or looking for? In such a situation, a visitor may feel alienated and as if they do not belong in that space.

Tate Modern offers an entry exhibition, called Start, particularly for visitors who may appreciate suggestions on how to visit an art exhibition and how to experience artworks. Curated by Ann Coxon and Tate Learning, the team has been empathic to ensure that the tone of the exhibition and its labels are not condescending. Instead, Start aims at disalienation. It offers tips to guide visitors through the rest of the museum, such as: don't feel like you have to see everything today; you don't have to like all the art; think about your first reaction to the work; and so forth. It also highlights words that are typical museum terms, but which may not be familiar to 
Figure 4.4 Start introductory panel

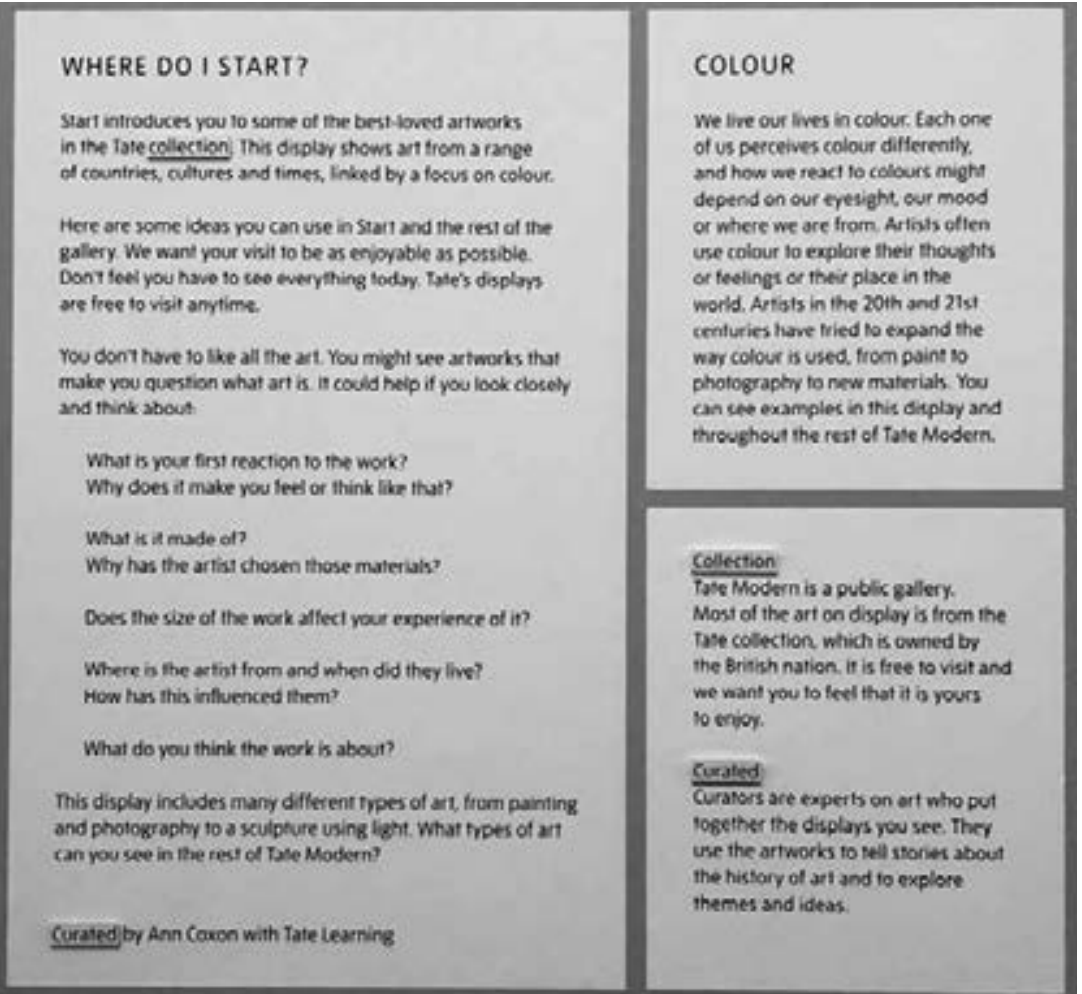

Tate Modern; photo by Csilla E. Ariese, 2019

inexperienced visitors, and then provides short definitions. The introductory panel is phrased predominantly in questions, allowing the reader to come to their own answers. The theme of the exhibition is color, a concept which is openly explored in all the artworks, allowing the spectator to grasp from the beginning what links all the works together.

The traditional object panels accompanying each artwork are expanded. An adjacent panel explains what types of information are on the object label, thus showing you where to look on the label for the name of the artist or where to find the reason for the artwork being in this exhibition. Furthermore, it contains a quote by the artist that relates to the theme color, making overtly clear connections between the artist, the artwork, and the exhibition. As such, Start is an empathic beginning of a path through Tate Modern, hopefully leading people to feel welcome, prepared, and knowledgeable enough for their visit. 


\section{Further reading}

Memorial Museums: The Global Rush to Commemorate Atrocities | Paul Williams $\mid 2007$

Nuts and Bolts: Developing a Toolkit for Emotion in Museums | Linda Norris and Rainey Tisdale $\mid 2017$

Words Matter: An Unfinished Guide to Word Choices in the Cultural Sector | edited by Wayne Modest and Robin Lelijveld | 2018

\section{Further examples}

The Museum of Broken Relationships

Zagreb, Croatia (created 20o6)

"The Museum of Broken Relationships is a physical and virtual public space created with the sole purpose of treasuring and sharing your heartbreak stories and symbolic possessions. It is a museum about you, about us, about the ways we love and lose. At its core, the museum is an ever-growing collection of items, each a memento of a relationship past, accompanied by a personal, yet anonymous story of its contributor. Unlike 'destructive' self-help instructions for recovery from grief and loss, the museum offers the chance to overcome an emotional collapse through creativity - by contributing to its universal collection." ${ }^{\text {10 }}$

BITTER Chocolate Stories exhibition at the Tropenmuseum

Amsterdam, the Netherlands (2019)

"Stories from children about cocoa plantations in Ghana and the Ivory Coast. More than 2 million child labourers work on cocoa plantations in Ghana and the Ivory Coast, and tens of thousands of children are victims of trafficking and forced labour in cocoa production. Who are these children and why do they work there? Six of them tell their story in BITTER Chocolate Stories: Valerie, Mohamed, Catherine, Bassirou, Sarata and Issaka. Because of these children, we - the chocolate consumers thousands of miles away - can eat the chocolate that we enjoy so much."11

10 As quoted from the Museum of Broken Relationships website. Available at https://brokenships. com/explore?open=about-museum (accessed 1 April 2021).

11 As quoted from the Tropenmuseum website. Available at https://www.tropenmuseum.nl/ en/whats-on/exhibitions/bitter-chocolate-stories (accessed 1 April 2021). 
Emotion networking method by the Reinwardt Academy and Imagine IC Amsterdam, the Netherlands (since 2011)

"Fascinated by the often-clashing emotions about museum collections, monuments, traditions and everyday cultural repertoires, they coined the term emotion networking. As a noun, emotion networks stand for the capricious constellations that form around heritage in everyday life. But emotion networking is also a verb. It is an exercise that provides insight into the complex interplay of emotions and interests surrounding heritage. The purpose of emotion networking is that participants see the mutual relationships change and thereby become (more) aware of the complex dynamics surrounding heritage. [...] The method is being further developed, for, with and in practice. ${ }^{12}$

With our thanks for this suggestion to Daniëlle Kuijten.

\section{Taking Care project lead by the Weltmuseum Wien}

Europe (2019-2023)

"The project TAKING CARE - Ethnographic and World Cultures Museums as Spaces of Care started on October 1, 2019 and places Ethnographic and World Cultures Museums at the centre [...] The project is organised around a set of interlinked themes, along a scale that starts from the museum as a site for care, opening towards thinking about the caring for the planet and its future, then on questions related to the unequal sharing of heritage resources and restitution. [...] Rather than think of the museum as spaces to come in from the worrisome street to see beauty, or to escape reality there is increasing demand for the museum to be that site where contestation can be engaged with in 'safe spaces'. [...] the central question [is] how ethnographic and world cultures museums can be activated to address the twinned concerns of planetary precarity and the precarity of plural societies." ${ }^{13}$

With our thanks for this suggestion to Wayne Modest.

12 As quoted from the Reinwardt Academy website. Available at https://www.reinwardt.ahk. $\mathrm{nl} / \mathrm{en} /$ research-group-cultural-heritage/emotion-networking/ (accessed 1 November 2020). 13 As quoted from the Taking Care website. Available at https://takingcareproject.eu/about (accessed 1 April 2021). 


\section{References}

Ariese-Vandemeulebroucke, Csilla E. 2018. The Social Museum in the Caribbean: Grassroots Heritage Initiatives and Community Engagement. Leiden: Sidestone Press.

de Varine, Hugues. 1978. "L’Écomusée." Gazette 11.2: 28-40.

Keyes, Allison. 2017. "In This Quiet Space for Contemplation, a Fountain Rains Down Calming Waters." Smithsonian Magazine [exhibition review], 21 September 2017. Available at https://www.smithsonianmag.com/smithsonian-institution/ quiet-space-contemplation-fountain-rains-down-calming-waters-180964981/ (accessed 1 April 2021).

Modest, Wayne, and Lelijveld, Robin, eds. 2018. Words Matter: An Unfinished Guide to Word Choices in the Cultural Sector. Work in Progress series. Wormerveer: Tropenmuseum, Afrika Museum, Museum Volkenkunde and Wereldmuseum. Ngũgĩ wa Thiong'o. [1986] 2004. Decolonising the Mind: The Politics of Language in African Literature. Nairobi: East African Educational Publishers.

Norris, Linda, and Tisdale, Rainey. 2017. "Nuts and Bolts: Developing a Toolkit for Emotion in Museums." Exhibition 2017 (Spring): 100-108.

Wiginton, Christina, and Holman Conwill, Kinshasha. 2016. The National Museum of African American History \& Culture: A Souvenir Book. Washington, D.C.: Smithsonian Books.

Williams, Paul. 2007. Memorial Museums: The Global Rush to Commemorate Atrocities. Oxford and New York: Berg. 


\title{
$5 \quad$ Improving Transparency
}

\author{
Magdalena Wróblewska
}

\begin{abstract}
Transparency is a crucial aspect of museums that nowadays are expected to be institutions of social trust and social justice. It concerns collections, whose provenances are more often than ever subjected to detailed examinations and whose published results increasingly have consequences, like planned restitutions. But it is also a much wider set of problems caused by museum practices related to colonial pasts that are not closed and often affect the present. One of them is authorship, understood in a wide sense as the privilege of presenting one's own point of view. Transparency also concerns museum policies, such as hiring, acquisition, management, and funding.
\end{abstract}

Keywords: ethics, provenance, restitution, inventories, exploitation, hiring policies

Transparency requires openness and a willingness to tell more than simple stories; it is sharing contestations and debates.

\section{The challenge}

In contemporary discussions about museums and their colonial pasts, transparency is mostly applied to the histories of collections. Museums are expected to reveal how items came to be stored in their collections and to speak out about bad acquisition practices. ${ }^{1}$ Furthermore, their audiences and stakeholders increasingly demand clear statements about past practices, as well as possible futures for colonial artefacts, not only those that were looted, but also those purchased and acquired in situations of power imbalances 
between the parties of such transactions. According to Alice Procter, who runs the Uncomfortable Art Tours in British museums that focus on the disputed provenance of certain exhibited objects, practices of imperial collecting were connected with the deep mechanisms of colonialism. She undermines the general, historical concept of the museum by calling it "a colonialist, imperialist fantasy, born from the fallacy that somehow the whole world can be neatly catalogued, contained in a single building, mapped out for easy digestion."

The hidden practices underpinning the circulation of objects with dubious or disputed provenance have become the primary focus of today's debate on the history of museum collections, even more so since the publication of the so-called Sarr and Savoy report. Officially titled The Restitution of African Cultural Heritage: Toward a New Relational Ethics, ${ }^{3}$ this report, which was commissioned by the President of France, Emmanuel Macron, and written by Felwine Sarr and Bénédicte Savoy, calls for the restitution of artefacts looted in the colonial era. But it also briefly describes the history of African cultural heritage within the context of European colonization, thus revealing the scale of the problem. According to the report, approximately $90 \%$ of all collected cultural heritage artefacts from sub-Saharan Africa are held in Western collections. Therefore, despite the controversy and critical opinions formulated from varied viewpoints contained within the report, its call for transparency and the necessity to publish knowledge about the history of collections and the provenance of particular objects is unlikely to be challenged.

However, transparency can also be understood more broadly as being open about colonial pasts and the current museum practices that continue to be affected by them. Among the most important aspects are: authorship (of exhibitions or texts), decision-making processes (relating to the museum program and hiring policy), and the power relations within the institution (including funding dependencies). These issues have been addressed over the last few years by museum professionals as well as social activists. In her 2016 TedX talk, Cinnamon Catlin-Legutko, President and CEO of the Abbe Museum in Maine, urged museum authorities to ensure that people from formerly colonized countries regained their voice and power. ${ }^{4}$ The same year, Museum Detox was established, a "network for people of color who work in museums, galleries, libraries, archives, and the heritage sector."5

2 Procter 2019.

3 Sarr and Savoy 2018.

4 Catlin-Legutko 2016.

5 As quoted from the Museum Detox website. Available at https://www.museumdetox.org/ museumdetox-about-us (accessed 1 April 2021). 
Led by Sara Wajid, Head of Engagement at the Museum of London, this network propagates the importance of diversity in cultural institutions, but also helps members to achieve leadership positions and "creatively use radical approaches to dismantle unjust infrastructures in our national cultural institutions." ${ }^{\prime 6}$

The debate was reignited two years later, when the Brooklyn Museum hired a white scholar as Consulting Curator of African Art. The problem of accessibility to museum positions for people of color was connected to the problem of the collection's provenance. A New York-based activist group called Decolonize This Place published an open letter in which they called the decision "tone deaf," and demanded the museum take part in the creation of a Decolonization Commission that would aim to diversify the museum's staff and review its inventory of colonial-era artefacts "with a view to settling the long-pursued claims of reparations and repatriation."

\section{The change}

Undertaking provenance research and sharing knowledge about object biographies is a fundamental task for any decolonizing museum activity that involves the collections. In 2019, three British museums took action to confront the colonial legacy of their objects and increase transparency in this regard. The British Museum, Victoria and Albert Museum, and the Pitt Rivers Museum are reviewing the labels on thousands of artefacts, especially those that were plundered during the colonial era. In 2017, the Victoria and Albert Museum appointed its first provenance curator to coordinate research in this field, while the Pitt Rivers Museum at Oxford University hired a research associate for the Labelling Matters project to define how the museum should proceed with reviewing the historical labels in its galleries. At the same time, serious doubts remain over whether such relabeling processes are capable of clarifying the complexity of object trajectories in every case, as many objects have complicated biographies that often involve plundering, transportation between countries, sales, exchanges, or even abandonment.

Therefore, many museums, much like the Victoria and Albert or the Tropenmuseum, rather than undertaking these relabeling projects in isolation, are approaching them within the broader context of programs that lead to

6 As quoted from the Museum Detox website. Available at http://museumdetox.com/\#team-5 (accessed 1 November 2020).

7 Decolonize This Place 2018. 
the recontextualization of the histories of objects and collections. However, another option for sharing complex and wide-ranging information is the innovative use of online databases. The Sarr and Savoy report postulates the publication of digitized information and research on the collections of colonial artefacts that would facilitate the process of making this knowledge available worldwide on the internet. ${ }^{8}$ Creating a digital archive of museum objects that includes information on their provenance can be an effective way to promote provenance research and transparency. And there are a number of major initiatives in this vein, including the Project for the Study of Collecting and Provenance being carried out by the Getty Research Institute, which makes use of the Getty Provenance Index Databases, containing 1.7 million records taken from the source material. A similar initiative, though much smaller in scale, is the Nazi-Era Provenance Internet Portal Project, a searchable registry of objects in US museum collections that changed ownership in Continental Europe between 1933-1945.

The call for transparency in museums is furthermore not only addressed to the management of objects in collections, but to people. There is an urgent need for cultural institutions to make long-term commitments to ethical and inclusive hiring policies, including at the executive leadership level, making museums more accessible to different social, ethnic, or economic groups and implementing a zero-tolerance policy towards racism, whether from staff or visitors. These postulates have been introduced since the turn of the century, and sometimes even earlier, by movements and activists' groups such as the Black Emergency Cultural Coalition, the Art Workers Coalition, and the Women Artists in Revolution. The Art+Museum Transparency collective provides examples of institutions that have made clear statements of intent, with a particular focus on those that have already started to follow these up with concrete actions. For example, the Walker Art Center, or the Vera List Center, which have drawn a direct analogy between racial justice and labor justice within the structures of cultural organizations.

\section{International Inventories Program | National Museum Nairobi \& Goethe-Institut Kenya | Nairobi, Kenya}

The International Inventories Program (IIP) is an initiative launched by the National Museum Nairobi and the Goethe-Institut Kenya in 2019. Its main aim is to create a comprehensive inventory of Kenyan cultural heritage in public institutions worldwide, in effect an international research and 
Figure 5.1 Screenshot of the home page of the International Inventories Program, 2021

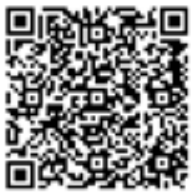

database project that investigates a corpus of Kenyan objects held in cultural institutions across the globe. IIP is a collaboration between: the National Museums of Kenya (NMK), the Rautenstrauch-Joest Museum in Cologne, the Weltkulturen Museum in Frankfurt, the SHIFT Collective in France and Germany, and the Nest Collective in Kenya. Other important goals are to create relationships of exchange and to strengthen the collaboration between NMK and key cultural institutions and collectors who possess and have custody of Kenyan objects by exchanging knowledge and information enabling these objects to be correctly identified, labeled, stored, and displayed.

Nanette Snoep, director of the aforementioned Rautenstrauch-Joest Museum, has stated that "there is a revolution happening in Germany's museums."9 Germany is under pressure, as neighboring countries such as the UK, the Netherlands, and France have already begun digitizing their collections and making them and their associated information available online. Consequently, at the beginning of 2019, the German government announced that over $€ 2$ million in state funds had been reserved for researching artefacts that had entered Germany's museum collections during the colonial era. This announcement, which was made by the German Commissioner for Culture and the Media, Monika Grütters, follows an appeal by over 80 scholars working in the fields of art history, ethnology, and history, who urged the German government to found an institute that would develop policies, research, and initiatives to address the nation's colonial past as well as the provenance of colonial objects in public collections. The funds are administered by the German Lost Art Foundation, which was founded by the German federal government in 2015 in an effort to assist with the restoration of Nazi-looted artworks after the Second World War.

However, conducting research and creating collection databases is a time consuming and costly task. Therefore, strategic interventions like the Appeal 
To Open German Museums' Inventories On African Objects might be a more productive way of gaining access to the required information. In the autumn of 2019, a group of internationally acclaimed anthropologists, archaeologists, artists, art historians, historians, jurists, philosophers, political scientists, writers, and other scholars signed a petition requesting that the German authorities open up the inventories and archives relating to African objects they have in their museums and other institutions. They argue that:

Transparency does not require tedious data processing and completed digitalization projects, as often claimed. Work on the inventories will never be complete and will always remain work in progress. There is no need to wait. For this reason, we demand that public museums and their supervisory authorities, municipalities, federal states and the federal government make the inventories of African objects in their respective collections available worldwide as quickly as possible, regardless of the degree of completeness or supposed perfection of these inventories. Simple scans and lists are sufficient. We need them now. Only then can the dialogue begin. ${ }^{10}$

\section{The Past Is Now | Birmingham Museum \& Art Gallery | Birmingham, UK}

In 2017, a group of six co-curators was invited to create an exhibition at the Birmingham Museum \& Art Gallery (BMAG) that would use the museum's collections to expose history in new and challenging ways, while also increasing awareness of how colonial processes impact our present times. To make the project even more inclusive, the museum authorities appointed only women of color with different heritage backgrounds: Abeera Kamran (graphic designer), Aliyah Hasinah (poet and activist), Mariam Khan (writer), Sara Myers (cultural activist), Shaheen Kasmani (textile designer), and Sumaya Kassim (writer and researcher).

During preparations for the new exhibition, these co-curators were given presentations by the collections' curators about the acquisition histories of the museum's objects. Many of them had been donated by colonialists, merchants, or collectors. According to Sumaya Kassim, ${ }^{11}$ one of the most famous and controversial objects is the Buddha Sakyamuni statue placed by the museum's entrance. It was 'discovered' in 1861 and 
Figure 5.2 Installation view of The Past Is Now exhibition

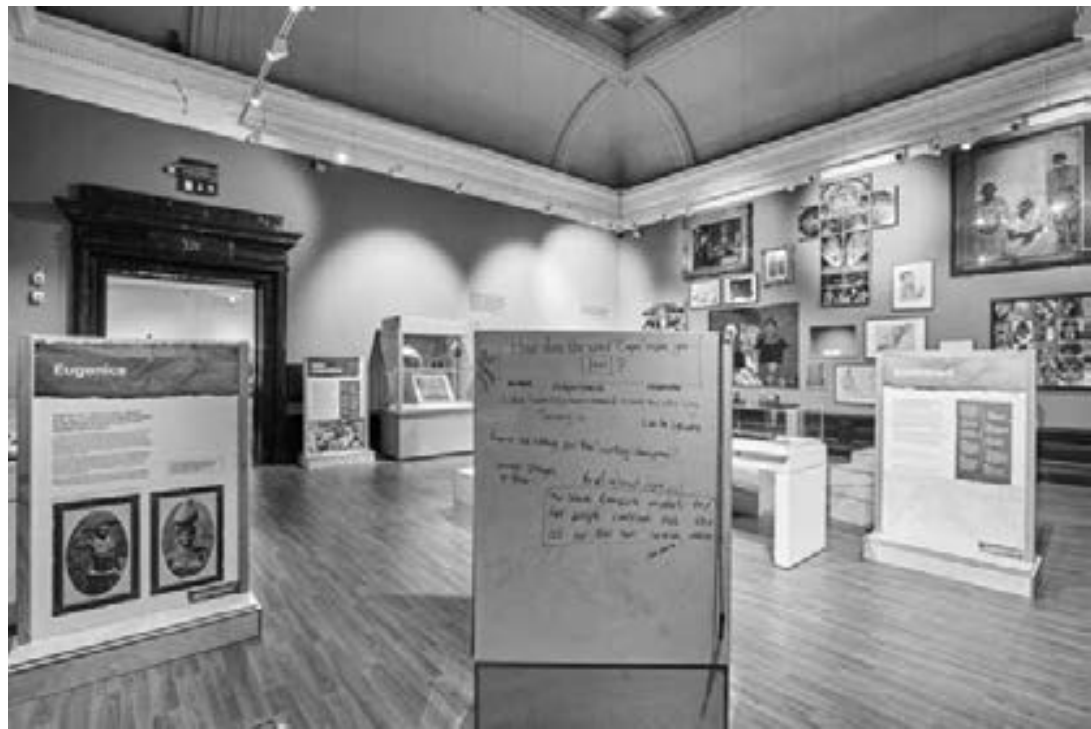

Birmingham Museum and Art Gallery, 2017; photo @ Birmingham Museums Trust

transported from Northeast India by British railway engineer E. B. Harris, who then sold it for £200 to a West Midlands industrialist whose foundries had produced many of the rails and carriages for the East Indian Railway. This industrialist then donated it to the BMAG. What struck Kassim was the fact that the statue's origins and the circumstances of its acquisition were seen as secondary to the value of the access to 'history' it could potentially grant to the British public. Consequently, the team was tasked with tracing the histories of particular objects in order to reverse dominant perspectives.

The curators not only focused on exposing the provenance of objects, but also decided to present Birmingham's involvement in imperial and colonial politics. A separate section of the exhibition was devoted to Joseph Chamberlain, the celebrated 'father' of the city. His half-forgotten role as British Secretary of the Colonies was brought back into focus along with his strong belief in imperial expansion and the superiority of the 'British race.' This part of the exhibition exposed his imperialist, racist ideology and revealed that social reforms introduced in Birmingham had been at the expense of the colonies. Along with this fuller examination of Chamberlain's legacy, all the deep connections between Birmingham and the Empire that 
are not often represented in the public spaces of the city were brought to light and explicitly linked to the museum's history.

The main focus of these curators' efforts, which might have corresponded to the expectations of the museum authorities, was to draw attention to the museum itself as an imperial structure that had failed to preserve history in a neutral manner because it had been governed by the old imperial rules. This issue is often illustrated with the classic Audre Lorde quote: "the master's tools will never dismantle the master's house. They may allow us to temporarily beat him at his own game, but they will never enable us to bring about genuine change."12 Inspired by this line of thinking, Sumaya Kassim decided to be open and transparent about the process of creating the exhibition. In her famous essay - and later video essay - The Museum Will Not Be Decolonised ${ }^{13}$ she raised some essential issues, like emotional labor, inadequate pay for work that had been undertaken, key decision-making taking place without the co-curators, and - one of the most difficult questions - the exploitation of people of color. In her words, "when projects and institutions proclaim a commitment to 'diversity,' 'inclusion' or 'decoloniality' we need to attend to these claims with a critical eye."'

\section{Museum of British Colonialism | Kenya \& UK}

The Museum of British Colonialism (MBC) is a collective based both in Kenya and the United Kingdom and was created by women activists in 2018. Its main roles are to promote a more transparent and objective account of British colonialism and to construct an opposite perspective to the fantasy of a benevolent colonial power accepted by native peoples on whom it mostly bestowed benefits. The activists involved in this collective encourage the public to undertake the uncomfortable but necessary process of confronting Britain's colonial past and slavery. For the past two years, they have been conducting research using different methods: gathering oral histories, making films, carrying out archaeological fieldwork, and creating digital exhibitions about Britain's colonialism. Another task was to envision possible ways of working with this difficult and challenging heritage.

The very first project implemented by the MBC focuses on documenting sites and experiences relating to the Mau Mau Emergency in Kenya (19521960), one of the most brutal conflicts that Britain fought to retain what 
Figure 5.3 Screenshot of the webpage for the exhibition Emergency
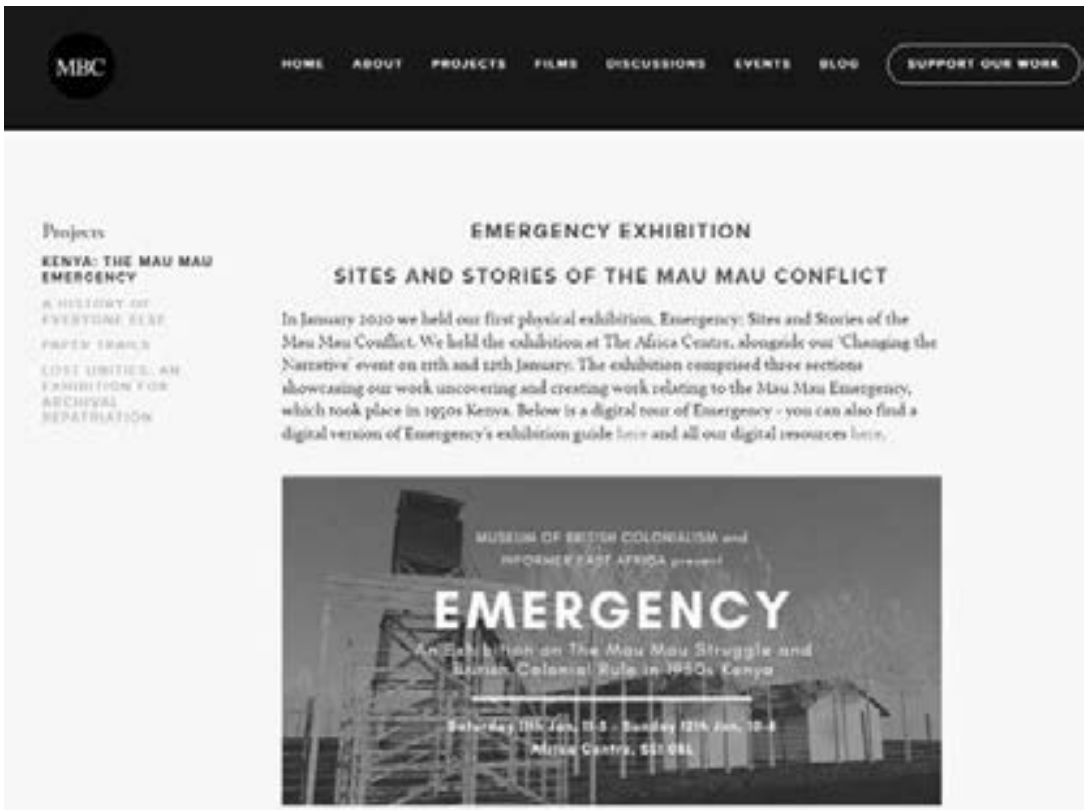

Museum of British Colonialism, 2021

remained of its Empire after the Second World War. It is also one of the least known episodes in British colonial history. Undocumented and relatively untold, the museum faced the problem of how to maintain transparency when writing this history while contending with the absence of sources caused by the burning or concealing of British archives. Therefore, a team of volunteers researched and visited a number of sites formerly used to detain and torture thousands of Kenyans. They collected a wealth of documentation, including oral testimonies from former detainees and contemporary and archival images.

For the MBC activists, transparency must also be applied to authorship. But the question of who should tell the story begs the further question of who has the right to do so. "The story of British colonialism belongs to its victims and those who fought for freedom. It belongs to their descendants, in nations that Britain robbed and actively impoverished - from India and Kenya to Nigeria and Jamaica,"15 says Gabriel Moshenska, Associate Professor in Public Archaeology at UCL and a member of the MBC team. It follows 
that telling the story right requires a new institution that would represent such marginalized and unheard voices. The members of the collective do not believe in the original concept of the museum institution because its history from the Renaissance cabinets of curiosities to 19th-century imperial collections has been shaped or infected by colonialism. Transparency, for them, can be only achieved in the museum institution once it has been invented anew: "to build a Museum of British Colonialism we need to discard all of this heritage and imagine a museum without walls, curators, collections or gift shops."16

So instead of gathering artefacts, the MBC has produced a number of media pieces including a podcast, documentary, short films, and a blog. The long-term plan is to create a collection of online resources accessible for further research and publication or exhibition projects. Physical, globally networked exhibitions are also being considered as a possibility, as the main goal is to build common awareness of past events and experiences in the colonial era. The MBC team envisions such a new museum institution in terms of collaborative, creative processes that lead to understanding and empathy within and between communities. Nevertheless, anyone following this path will need to uncompromisingly confront a difficult, sometimes shameful past.

\section{Musée des Civilisations Noires | Dakar, Senegal}

The Musée des Civilisations Noires (Museum of Black Civilizations; MCN) which opened on 6 December 2018, is a national museum in Dakar, Senegal, with a mission to propagate Africa's overlooked contributions to the world's cultural, scientific, and technologic patrimony. It is the realization of a dream of Léopold Sédar Senghor, post-independence Senegal's first president, to create a museum that would represent the histories and contemporary cultures of black people across the globe. ${ }^{17}$ His vision for the museum is entirely in the spirit of the Pan-Africanist movement. ${ }^{18}$ For centuries, African histories have been told by others and their art and material heritage were taken by and kept in Western museums. Therefore, the new institution has two main goals: to tell the history of Africa and its diaspora from an African perspective and to provide a repository for African art and heritage in Africa. Thus, the ambition of this new pan-African institution is to change the 
dominant narrative and to play an active role in the restitution of artefacts plundered during the colonial era.

The MCN's displays span many centuries and continents and are divided into thematic sections to present both the histories and contemporary cultures of black people in a global context. The exhibitions are not intended to be permanent, but rather to rotate frequently to reflect the dynamics of civilizations. ${ }^{19}$ Their topics are illustrated with artefacts including early stone tools and masks. However, contemporary artworks are equally important in these narratives, such as works by Cuban Elio Rodriguez, South African Andries Botha, or Haitian Philippe Dodard. Exhibition curators have included them to emphasize how African history and culture continuously thrive and to showcase that the MCN does not only look back to the past. The museum includes both tangible and intangible heritages to actively engage in the process of shaping Africans' sense of identity in the present.

The MCN was opened a year after President of France Emmanuel Macron declared on his Twitter account that "African heritage can no longer remain a prisoner of European museums. ${ }^{\text {20 }}$ As such, the institution was perceived as an important step forward in the efforts to reclaim African artefacts looted during colonial times. The colossal, modern building has space for 18,000 objects and many of the galleries are not yet filled. Other galleries display objects on loan from European museums, such as the Musée du Quai Branly in Paris or the Royal Museum for Central Africa in Tervuren. Senegal has formally requested repatriations from French collections and there is some hope to regain some of those objects. The very first request, and a symbolic one, is a sword originally belonging to Omar Saidou Tall, an Islamic scholar and West African ruler who led an anti-colonial siege against the French in the 1850 os. $^{21}$

MCN Director Hamady Bocoum emphasizes that although restitution is important, it is not their main priority because African history should not be reduced to the relatively brief period of colonization: "if the timeline of African humanity were just one day, he said, colonization and slavery 'were just one minute."”22 Instead the MCN pursues a broader mission to cover 7 million years of African civilizations in a global context. Yet, by providing physical space for repatriated objects and by vocally advocating for the 
restitution of African material heritage, the MCN plays an important role in this global debate. On the one hand, the existence of the museum counters an oft-heard excuse for not arranging object repatriation, namely that objects are 'better cared for' in their current European storages. On the other hand, the ongoing active requests for object repatriations, as well as the efforts to legally regain items currently on loan, push European museums to research their collections, engage in uncovering object biographies, and clarify object provenances. Thus, the work of the Musée des Civilisations Noires effectively results in other museum institutions improving their transparency when it comes to their colonially obtained objects.

We would be remiss if we did not reflect on the funding of the MCN. The creation of the museum was possible due to a major investment by the Chinese government of $\$ 34$ million, ${ }^{23}$ and the design is by Chinese state architects. China has been investing heavily in the African continent, for instance in infrastructure, and has also engaged in providing funding for cultural projects and institutions in Africa, Asia, and the Caribbean. Chinese investments are mainly intended to increase trade and access to African raw materials, but there is also a political dimension to China's interest in Africa. Financially, a number of these Chinese investments have resulted in debt and some have called these debt traps a new form of colonialism - although others have countered that this underestimates the decisionmaking powers of African governments. ${ }^{24}$ In the cultural sphere, however, Chinese involvements abroad can be intended to influence aspects such as sense of identity, perspectives on history, and systems of knowledge. ${ }^{25}$ In the case of the MCN, they have been transparent about their Chinese funding and have said that their operations will be independent. ${ }^{26}$ Nonetheless, this could become a source of conflict in the future if the independence of the museum were to be restricted.

\section{Further reading}

Dossiê "Patrimônio Indígena e Coleções Etnográfıcas" | edited by Jimena Felipe Beltrão | 2017

Exclusive Labels | Pauline Turner Strong | 1997 


\section{Further examples}

Black Models: From Géricault to Matisse exhibition at the Musée d'Orsay Paris, France (March-July 2019)

"Taking a multi-disciplinary approach that combines the history of art and the history of ideas, this exhibition explores aesthetic, political, social and racial issues as well as the imagery unveiled by the representation of black figures in visual arts, from the abolition of slavery in France (1794) to the modern day."27

"Object labels that indicate how titles have changed over the years help audiences to understand the vagaries of naming and point to their political implications. For instance, the label for Eugène Delacroix's Portrait d'une femme au turban bleu (Portrait of a Woman in a Blue Turban) (1827-28) states that it was formerly known as Tête d'étude d'une Indienne (Study of the Head of an Indian Woman), Une tête de femme mulâtre (A Mulatto Woman's Head), and Aline la Mulâtresse (Aline the Mulattress). These shifts demonstrate the mutability of the idea of race in general and of the woman of color in particular, who could transform from an Indian to a 'mulâtresse,' to a named individual, and eventually back to an anonymous woman in a blue turban." ${ }^{28}$

Dead Images exhibition at the Edinburgh College of Art

Edinburgh, UK (2018)

"Part of the TRACES project, DEAD IMAGES is an artistic exploration of the complex and contentious legacy of collections of human skulls held by public institutions in Europe. [...] We live with this legacy. It resides in our cities. Often it is hidden but it is still with us. The DEAD IMAGES exhibition [...] brings this legacy to light by exhibiting a life-sized 30 meter photograph of part of one such collection, a gathering of more than 8,000 skulls which resides on shelves along a corridor in the Natural History Museum of Vienna. In exhibiting this photograph, this exhibition asks questions of ourselves, our ambivalent curiosity and our own desire to see that which is withheld. [...] We explore these questions through a series of filmed works, in which different people speak to this history, their own beliefs and feelings and whether or not we should display this

27 As quoted from the Musée d'Orsay website. Available at https://www.musee-orsay.fr/en/ events/exhibitions/archives/archives/browse/2/article/le-modele-noir-47692.html (accessed 1 April 2021).

28 Childs 2019. 
photograph. The choice to see the photograph, finally, rests with the visitor and in making a choice visitors are asked to reflect upon this history, the work of bringing this history to light, the ethics and politics of making such a display visible and the role that descendants, curators, scientists, artists and the public may play in reimagining a place and purpose for these remains of once-living people."29

With our thanks for this suggestion to Anna Szöke.

The India Museum Revisited project by the Victoria and Albert Museum London, UK (since 2019)

“In a post-colonial era, the East India Company's museum has attracted commentators who have attributed to it motives unsupported by surviving archival and physical evidence. A new survey will establish an objective basis for future analysis. At the dispersal of the India Museum in 1880, most of the objects came to the South Kensington (V\&A) Museum, where they were listed. Addressing that and an earlier register, subsequent publications, the V\&A's Collections Management System and the objects themselves, a consolidated account of the contents will be produced for the first time. The exhibits will be analysed, grouped according to their original function and their role within the museum; their sources will be charted and interrogated, and the intentions of the donors assessed." ${ }^{\circ 0}$

In a Different Light exhibition at the Museum of Anthropology at UBC Vancouver, Canada (2017-2021)

"In a Different Light presents more than 110 historical Indigenous artworks and marks the return of many important works to British Columbia. These objects are amazing artistic achievements. Yet they also transcend the idea of 'art' or 'artifact.' Through the voices of contemporary First Nations artists and community members, this exhibition reflects on the roles historical artworks have today. Featuring immersive storytelling and innovative design, it explores what we can learn from these works and how they relate to Indigenous peoples' relationships to their lands. With the increasing impacts of colonization in the 19th century, many Northwest Coast objects were removed from their communities. As they circulated through museums and private collections, their histories were often lost. Indigenous community members are now reconnecting with

29 As quoted from the Dead Images brochure.

30 As quoted from the Victoria and Albert Museum website. Available at https://www.vam. ac.uk/research/projects/the-india-museum-revisited (accessed 1 April 2021). 
these objects and rebuilding their past. Through their eyes, you will come to see these artworks in a different light - as teachers, belongings, even legal documents." ${ }^{1}$

\section{References}

Catlin-Legutko, Cinnamon. 2016. "We Must Decolonize Our Museums | TEDxDirigo." YouTube [video lecture], 6 December 2016. Available at https://www.youtube. com/watch?v=jyZAgG8--Xg (accessed 1 April 2021).

Childs, Adrienne L. 2019. "Exhibition Review of 'Le Modèle Noir de Géricault à Matisse." Nineteenth-Century Art Worldwide 18.2. DOI: doi.org/10.29411/ ncaw.2019.18.2.18.

Decolonize This Place. 2018. "Open Letter to the Brooklyn Museum: Your Curatorial Crisis Is an Opportunity to Decolonize.” Decolonize Brooklyn Museum [letter], 3 April 2018. Available at https://decolonizebrooklynmuseum.wordpress. com/2018/04/03/the-journey-begins/ (accessed 1 April 2021).

Felipe Beltrão, Jimena, ed. 2017. “Dossiê 'Patrimônio Indígena e Coleções Etnográficas." Boletim Museu Paraense Emílio Goeldi: Ciências Humanas 12.3: 709-789.

ICOM. 2017. ICOM Code of Ethics for Museums. Paris: International Council of Museums.

Kassim, Sumaya. 2017. “The Museum Will Not Be Decolonised." Media Diversified [essay], ${ }_{5}$ November 2017. Available at https://mediadiversified.org/2017/11/15/ the-museum-will-not-be-decolonised/ (accessed 1 April 2021).

Katz, Brigit. 2018. "Sprawling Museum of Black Civilizations Opens in Senegal." Smithsonian Magazine [exhibition review], 10 December 2018. Available at https://www.smithsonianmag.com/smart-news/sprawling-museum-blackcivilizations-opens-senegal-180970976/ (accessed 1 April 2021).

Kimeria, Ciku. 2019. "Dakar's Museum of Black Civilizations Is a Vital Step for a People Reclaiming their History." QuartzAfrica [exhibition review], 25 January 2019. Available at https://qz.com/africa/1533523/dakars-museum-of-blackcivilizations-tells-africas-story/ (accessed 1 April 2021).

Lorde, Audre. 1984. Sister Outsider: Essays and Speeches by Audre Lorde. Berkeley: The Crossing Press.

Macron, Emmanuel. 2017. “Aujourd'hui nous sommes orphelins d'un imaginaire commun: le patrimoine africain ne peut pas être prisonnier de musées

31 As quoted from the Museum of Anthropology at $U B C$ website. Available at https://moa.ubc. ca/exhibition/in-a-different-light-reflecting-on-northwest-coast-art/ (accessed 1 April 2021). 
européens." Twitter [post], 28 November 2017. Available at https://twitter.com/ EmmanuelMacron/status/935488489663156226?s=20 (accessed 1 April 2021).

Moshenska, Gabriel. 2020. "Creating a Museum of British Colonialism." New African [article], 16 September 2020. Available at https://newafricanmagazine.com/24035/ (accessed 1 April 2021).

Oelze, Sabine. 2019. "How a Cologne Museum Is Dealing with its Colonial Heritage." $D W$ [article], 10 January 2019. Available at https://p.dw.com/p/3QUcG (accessed 1 April 2021).

Opoku, Kwame. 2019. “Appeal To Open German Museums' Inventories On African Objects." Modern Ghana [feature], 15 October 2019. Available at https://www. modernghana.com/news/961408/appeal-to-open-german-museums-inventorieson-afri.html (accessed 1 April 2021).

Pozzi, Laura. Forthcoming. "China, the Maritime Silk Road, and the Memory of Colonialism in the Asia Region.” In Simon Lewis, Jeffrey K. Olick, Małgorzata Pakier, and Joanna Wawrzyniak, eds. Regions of Memory: Transnational Formations. London: Palgrave.

Procter, Alice. 2019. "UK Museums Should Be Honest about Being Stuffed with Stolen Goods." The Guardian [opinion], 20 February 2019. Available at https:// www.theguardian.com/commentisfree/2019/feb/2o/uk-museums-honest-stolengoods-imperialism-theft-repatriation (accessed 1 April 2021).

Sarr, Felwine, and Savoy, Bénédicte. 2018. The Restitution of African Cultural Heritage: Toward a New Relational Ethics. Paris: Ministère de la Culture.

Searcey, Dionne, and Nayeri, Farah. 2019. "Senegal's Museum of Black Civilizations Welcomes Some Treasures Home." The New York Times [exhibition review], 15 January 2019. Available at https://www.nytimes.com/2019/01/15/arts/design/ museum-of-black-civilizations-restitution-senegal-macron.html (accessed 1 April 2021).

Stoudmann, Elisabeth. 2020. "Hamady Bocoum: 'Nous sommes tous des Africains'." Le Temps [interview], 27 March 2020. Available at https://www.letemps.ch/ culture/hamady-bocoum-sommes-africains (accessed 1 April 2021).

Turner Strong, Pauline. 1997. "Exclusive Labels: Indexing the National 'We' in Commemorative and Oppositional Exhibitions." Museum Anthropology 21.1: 42-56. Were, Anzetse. 2018. "Debt Trap? Chinese Loans and Africa's Development Options.” South African Institute of International Affairs 66: 1-12. 


\title{
$6 \quad$ Embracing Vulnerability
}

\author{
Magdalena Wróblewska
}

\begin{abstract}
Vulnerability, in the context of the museum, means the capacity to be in a state of openness, of exposure to attack or harm. It is a mode of awareness that can be developed in response to colonial, violent actions of the museum in the past, in hopes of overcoming it. Vulnerability in the museum can also be experienced by the visitor, within an exhibition or any other museum activity, when the contents touch difficult matters and the form enables emotional, intimate, and compassionate relationships with the story and its actors. Vulnerability is a training in receptivity that enables epistemic and ethical transformations, both of the museum and its visitors.
\end{abstract}

Keywords: receptivity, sensitivity, ethical transformation, ethics of failure, community relationships

Exposing weaknesses, doubts, and work-in-progress requires courage, but embracing such vulnerability leads to stronger, more inclusive institutions and individuals.

\section{The challenge}

Vulnerability, defined as "the quality or state of being exposed to the possibility of being attacked or harmed, either physically or emotionally," is one of the most desirable virtues of today's museums. Criticized for their traditional forms as violent, imperial, and dominating institutions of the modern system of knowledge, some museums have already developed the capacity for self-reflection and self-critique in their regular activities. Some have created new strategies, such as inviting criticism from the outside, for

Ariese, Csilla E., and Magdalena Wróblewska, Practicing Decoloniality in Museums: A Guide with Global Examples. Amsterdam, Amsterdam University Press 2022 DOI: 10.5117/9789463726962_CHo6 
instance by cooperating with an artist or curator or by establishing dialogues with engaged communities. However, vulnerability, understood as a mode of awareness and openness, requires even more - namely, a near-constant exposure and susceptibility to the risk of being attacked and harmed - as it emerges from imagining what it is to feel otherwise. ${ }^{1}$

Vulnerability is the capacity to imagine, feel, and see without excluding. It is the extension of work towards making the museum more accessible and more inclusive, to develop empathy for and identification with varied communities. It is also often defined as openness to an encounter with the 'other' as being different. Therefore, the real value of vulnerability is the possibility to transform existing perceptions of self, others, and the world. ${ }^{2}$ It may evoke a deepened sense of responsibility in museum staff as well as in visitors. It brings the promise of museums that are more equitable in their approaches, their content, and their engagement in power structures. ${ }^{3}$ Vulnerability is a virtue developed in communities to contest injustice, and it entails opening up to an ethical transformation.

Vulnerability is also the basis for learning and for understanding, as it facilitates connections and the building of a sense of community. Thus, it has become one of the key concepts in museum education nowadays, applied to both parts of the process. On the one hand, it is understood as an experience of 'being touched,' as an inherent part of the teaching-learning relationship, but vulnerability also requires letting down one's guard and abandoning the position of authority to reveal mistakes, struggles, uncertainties, and failures. This is an essential condition for continuing the growth and learning process, as opposed to the repetition of fixed knowledge.

Vulnerability additionally requires unprecedented openness to the voices of others, to the opinions and critiques of the museum's visitors, interested communities, and social activist groups. To remain relevant, museums must change their status from authorities of knowledge to a part of the learning community. Olga Viso, the director of Minnesota's Walker Art Center, concurred:

If museums want to continue to have a place, they must stop seeing activists as antagonists. They must position themselves as learning 
communities, not impenetrable centers of self-validating authority. If they do not, museums run the risk of becoming culturally irrelevant artifacts. ${ }^{4}$

Museums must train themselves in receptivity. Listening carefully to critical voices and uncomfortable stories and accepting them on equal terms is the only way for deep epistemic and ethical transformation to occur, which is necessary for the museum to be a relevant partner for communities.

\section{The change}

Vulnerability in a museum space may be an unexpected experience, when visitors encounter within the exhibition or in a museum program content that touches them, wounding or overwhelming them on a deep, personal level. It happens mostly when difficult matters, such as the Holocaust, childhood war experiences, or slavery are the subject of the exhibition, educational program, or publication offered by the museum. ${ }^{5}$ Such experiences can be evoked intentionally, when a painful past is recalled in its private, individual dimension, when the museum puts a face on history, for example by using the personal stories of victims. Feelings of close encounters, intimate relationships, and proximity to the life stories of other people open us up to new experiences and understandings of the past. However, it brings a risk of unwanted harm and pain on the part of the learner, as Tinning noted. ${ }^{6}$ Therefore, learning how to deal with uncomfortable moments and how to build on these experiences is an important part of such projects and should be facilitated by museum staff.

But vulnerability is an experience that is not only limited to the audience, but rather should embrace all parts of the process. One of the ways to improve vulnerability in the museum institution is collaboration with external experts and partners. Museums often invite artists, writers, or scholars for dialogues, cooperation, or exchanges of thoughts and experiences. Sometimes in the form of longer residencies. In the case of practicing decoloniality, however, there is always a risk of tokenizing, as described by Sumaya Kassim. ${ }^{7}$ Western museums may expect these invited artists, curators, or academics from formerly colonized countries or from their diasporas

$4 \quad$ Viso 2018.

5 Tinning 2018.

6 Tinning 2018.

7 Kassim 2017. 
to create or present work that would somehow 'mine the museum,' thus proving the self-reflectivity and self-critique of the institution. Namibian scholar and artist Nashilongweshipwe Mushaandja names this a 'practice of museuming,' when authorities "ask the victims of colonialism to handle its baggage." ${ }^{8}$ To avoid it, museums should not only carefully listen to the voices of invited collaborators and follow their observations and intuitions, but also make changes based on what was learned during such a project.

In an effort to embrace vulnerability, museums can also engage with communities, especially those who are disappointed or dissatisfied with the museum's activities or its profile. This creates a wide platform for vulnerability practices, if the institution is capable of listening to the voices of those disappointed and dissatisfied and able to adequately respond to them in future activities. In that case, vulnerability means being truly open for critique. It is actively dealing with uncomfortable opinions and situations instead of getting defensive and denying or hiding any problems. It is the courage to expose weaknesses, present infirmities, and share uncertainties, instead of holding on to an infallible position of authority. By listening to other (dissenting) voices and changing practices, museums can turn into instruments of social justice. ${ }^{9}$ Participatory approaches ${ }^{10}$ enable museums to change into more comfortable and fair institutions for those who for many reasons (e.g. social, health, cultural) may not feel like they are truly a part of them. Vulnerability requires truth and courage which are certainly not always comfortable. Yet, it helps to deepen relationships, if there is genuine engagement in all parts of the processes and experiences.

\section{The Museum of Others | Pitt Rivers Museum | Oxford, UK}

In 2016, the Pitt Rivers Museum (PRM) opened a permanent display of Christian Thompson's works in its Lower Gallery. In 2010, this artist invited to the museum exhibition had become the first Aboriginal Australian to be admitted into the University of Oxford and he began to work closely with the collections and staff of the Pitt Rivers Museum. Two years later, invited by curator Christopher Morton, in response to the museum's photograph collection he exhibited his new work there titled We Bury Our Own, which travelled internationally afterwards and received great acclaim. His later project presented in the Lower Gallery is a series of photographs titled The 
Museum of Others (2016). Thompson portrayed himself hidden behind and looking through the holes made in the eyes of the photographic images of several key figures in the British tradition of art and museum culture, including art critic John Ruskin, explorer Thomas Cook, anthropologist Walter Baldwin Spencer, and, last but not least, archaeologist Augustus Pitt Rivers (1827-1900), the founder of the museum.

Both projects refer to the PRM's history and collection. As a part of the University of Oxford, it was established in 1884 by Augustus Pitt Rivers to maintain the relationship of anthropological and archeological collections with the broad system of knowledge. He donated his international collection of about 22,000 objects on the condition that a permanent lecturer in anthropology must be appointed. Pitt Rivers and later donors sourced many items in the collection, such as the Benin bronzes, through violent and exploitative means recalled in the Sarr and Savoy report, ${ }^{11}$ including military punitive campaigns. Nevertheless, Pitt Rivers was highly esteemed in the scientific circles of his time for innovations in archaeological methodologies and in the museum display of archaeological and ethnological collections. Physically and structurally, the museum was, and still remains, a monument of colonialism, with 55,000 objects densely layered in dark wooden cases. The objects are still organized in line with the requests of the benefactor, according to type instead of cultural group or geographical location. This seems highly unusual and even controversial nowadays, as it makes it even more difficult for a visitor to trace the origins of particular objects.

Pitt Rivers was also one of the scientists responsible for the 'othering' of Aborigines; he actually built his career upon it. He believed in Social Darwinism and organized his collections from this explicitly racist and imperialist perspective. ${ }^{12}$ Therefore, a photograph of Thompson looking at visitors through the eyes of the museum's patron in one of the works from the series The Museum of Others, titled Othering the Ethnologist, Augustus Pitt Rivers, is truly moving and opens up a new perspective. The simple gesture of reversal raises important questions. Who is observing in the museum and who is being observed? Who is the 'other' to whom? With the faces of notable British colonial figures transformed into masks, Thompson evokes an uncanny feeling and causes discomfort in the viewer. He also touches a raw nerve in the institution, as his questions about the divisions and classifications of the world relate not only to the colonial past, but are distressingly relevant in the present museum setting. 
Figure 6.1 Othering the Ethnologist, Augustus Pitt Rivers

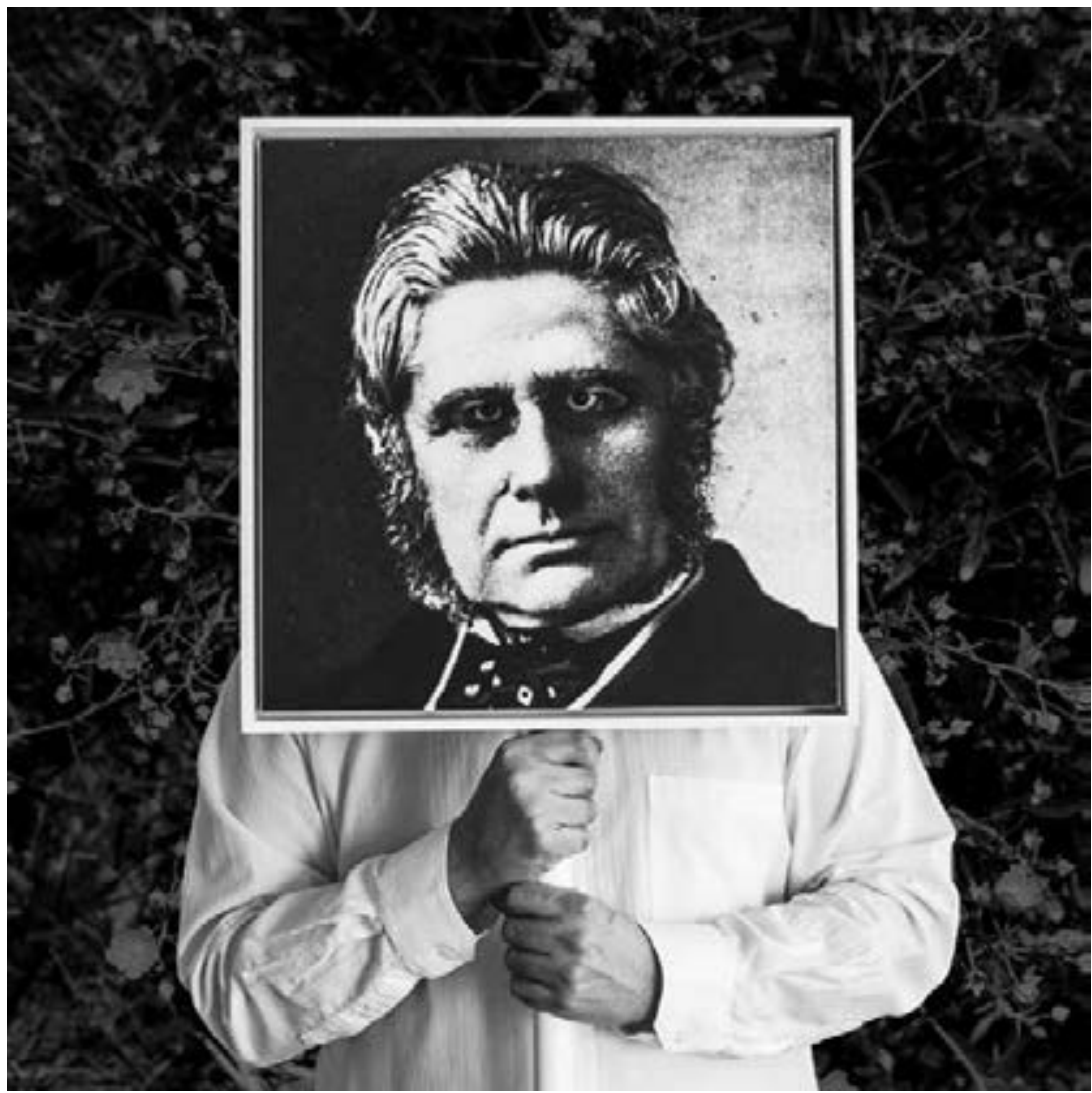

Christian Thompson, 2016; courtesy of the artist and the Yavuz Gallery

\section{Scaffold | Walker Art Center | Minneapolis, USA}

In 2015, the Walker Art Center (WAC) in Minneapolis acquired a public sculpture, Scaffold, by Sam Durant to place in the institution's sculpture garden that was to be opened in May 2017. The work, which had first been exhibited at $d O C U M E N T A 13$ in 2012 in Kassel, depicts gallows that represent seven major state-sanctioned executions in US history between 1859 and 2006. Its intent was to critique the persistence of the death penalty in American democracy as well as the racial dimension of the criminal justice system in the United States. However, part of it, which recalled a particular event in Minnesotan history, was seen by the local Native communities as a painful traumatic trigger. It was the re-creation of the 1862 scaffold 
used to put to death 38 Dakota Sioux men in the largest mass execution in American history.

The sculpture drew protests from the Native American community and, in response, Olga Viso, then director of the WAC, published a letter on 26 May 2017 admitting that she had failed to engage leaders of the Dakota and broader Native communities in advance of the work's siting. ${ }^{13}$ She apologized for the pain that the sculpture elicited and announced a consultation with Dakota community members. A few days later, after a three-hour mediation session attended by Durant, representatives from the Dakota Spiritual and Traditional Elders, the four federally recognized Dakota tribes, the WAC, and the Minneapolis Park and Recreation Board, the decision to remove the work was announced.

In a joint statement following the mediation session, the parties presented a plan for the sculpture's removal and ceremonial burning. Durant offered the sculpture and its intellectual property rights to the Dakota. A native construction company donated its services and dismantled the piece, beginning on 2 June, in a ceremony overseen by Dakota Spiritual and Traditional Elders, as the WAC donated an equivalent amount to fund the travel of elders to the ceremony. The wood was buried at Fort Snelling, where Dakotas were imprisoned following the 1862 US-Dakota War. As part of the final agreement, the WAC and Durant pledged never to reconstruct the work. The willingness and openness of all parties (the artist, Dakota elders, Minneapolis City officials, and the WAC staff and board) to engage in mediation helped to achieve a satisfying resolution.

This process would not have been possible if the old hierarchies, in which a museum's authority and the preservation of its collections are prioritized over the audience's feelings and expectations, had still been in place. As Viso said:

It is not easy to acknowledge one's blind spots. What I had hoped would be an opportunity for public education and 'truth to power' in the presentation of Scaffold was simply not possible because of the continuing historical trauma about an unreckoned-with colonial past. ${ }^{14}$

Additionally, Durant acknowledged that he had developed a new understanding of the considerable sensitivity surrounding the mass killing and he never would have included the Mankato gallows in such a work. The education 
Figure 6.2 Removal of Sam Durant's Scaffold following mediation and a joint decision

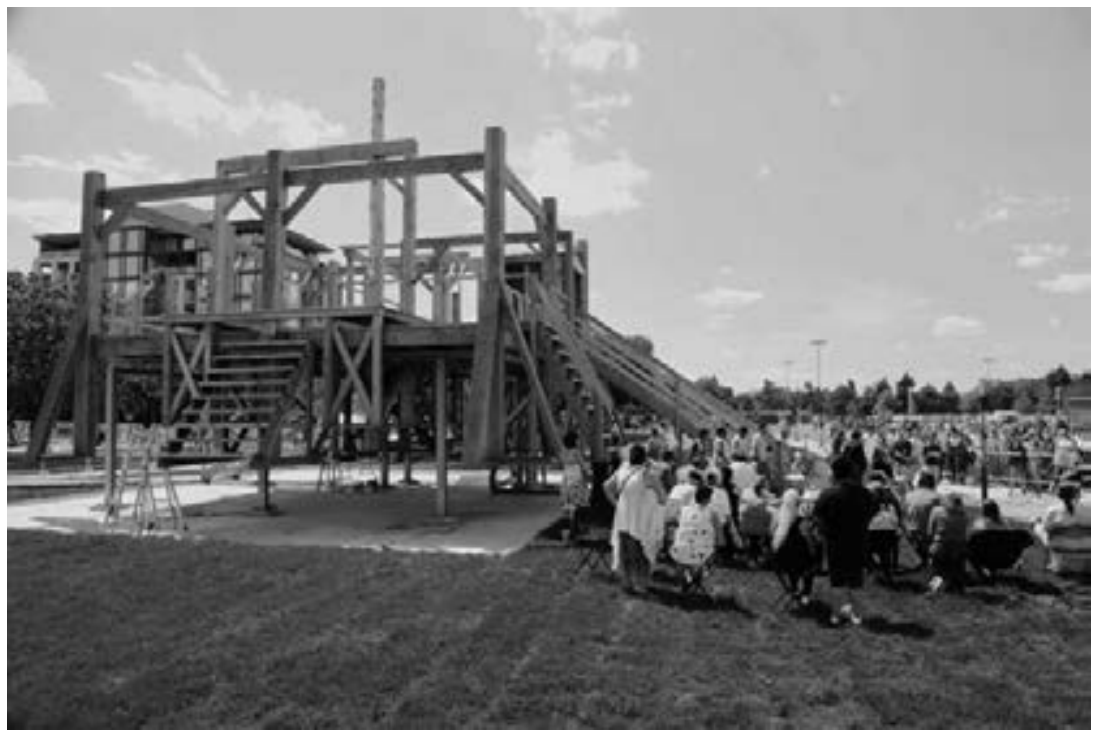

Walker Art Center; photo @ Walker Art Center, 2017

they both were open and willing to receive helped Viso and Durant to understand the Dakotas, and respond to their feelings and expectations. The whole process of negotiation was based on listening to painful truths, learning, and healing.

\section{Muzeum krytyczne (Critical Museum) by Piotr Piotrowski | Warsaw, Poland}

The book Muzeum krytyczne (Critical Museum) was published in 2011 by art historian, curator, and art critic, Piotr Piotrowski (1952-2015), professor at the Adam Mickiewicz University in Poznan and former director of the National Museum in Warsaw (NMW). It presents his concept of the 'critical museum,' developed originally for the main national institution in Poland, which he headed for nearly a year in 2009-2010. He resigned after the Board of Trustees rejected his program of reform of the then rather conservative and inert institution, even though his plan had initially been accepted by this same body a year before. Piotrowski's idea of the critical museum is rooted in the New Museology movement which aims at the denaturalization and 
Figure 6.3 Ars Homo Erotica exhibition

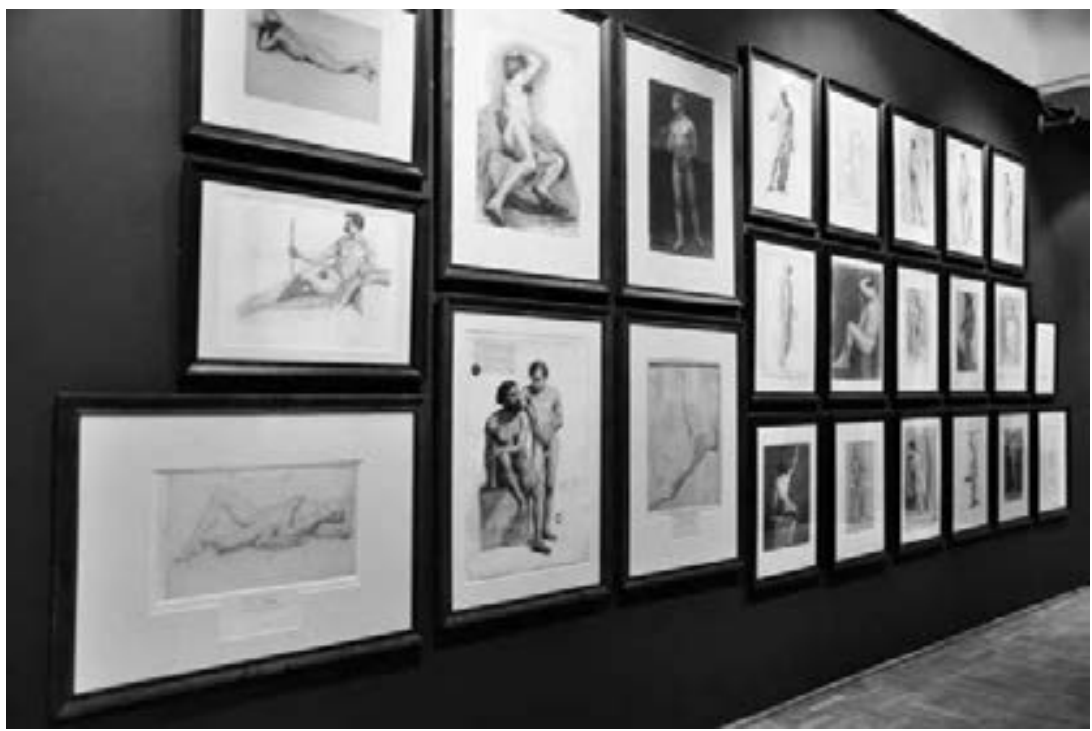

National Museum in Warsaw; photo by Raman Tratsiuk, 2010

denormalization of the museum institution whose foundations, organization, and collections are not politically neutral. ${ }^{15}$

Piotrowski started his reflections by recalling some of the most crucial postulates of the New Museology, such as a critical interpretation of a museum's history. A reflection on the imperial entanglements of particular museum institutions or even of the very concept of the museum, is the departing point of his idea of the critical museum. It follows for Piotrowski that every museum reflects universalism and a hegemony of empire, therefore absolutizing and objectifying the narratives it presents. This manifests itself mostly in the canon established through the collections. As a result, the canon can be a source of a complex, for instance when the collections of a peripheral museum, such as the National Museum in Warsaw, do not reflect the paradigm of central art institutions.

In his project, Piotrowski bravely presented the history of the National Museum in Warsaw as a kind of failure: due to political and financial reasons, museum authorities in this provincial city of the Russian Empire failed to create a collection according to the canon of European art. Moreover, this could be seen as a second failure, following upon the earlier project of 
the last Polish king, Stanisław August Poniatowski, who at the end of 18 th century aimed to create such a collection that would be accessible to the public. Finally, the Nazi occupation of Poland and Warsaw during WWII and the extensive looting of the collections determined their current shape. Nevertheless, the galleries and permanent exhibitions of the NMW are shaped according to the dominant, Western canon of art and imitate it against all odds, despite the lack of 'masterpieces' in the collection which contains only a few examples of works by great masters that are recognizable to a wider audience. This provincial fixation which had been neglected for a long time was directly expressed by Piotrowski: "the National Museum in Warsaw cannot compete with the Prado or Hermitage, with the National Gallery in London or the Museum of Fine Arts in Budapest, it cannot compete with the Louvre, neither with its brand, nor with its collections, nor with the attractiveness of the place." 16

For Piotrowski and his close collaborators, particularly Katarzyna Murawska-Muthesius, this exposure of weaknesses was a starting point for the plan of the new institution. Instead of imitating the established canon, they proposed to focus on local specificity and to build on that which was perceived as unattractive. For although the collection lacks paintings by old masters, it has a great selection of local modernist and contemporary art, of which the latter had not been the subject of any deeper interest before. This approach further allowed them to question the dominant canon from a peripheral position, taking inspiration from Dipesh Chakrabarty's Provincializing Europe. ${ }^{17}$ Afterwards, by leaving the issues of painful history behind them, they were able to define the current problems that the NMW should be dealing with: of an expanding metropole in Central-Eastern Europe, migration and minorities, and disadvantaged groups with difficult or limited access to the museum's offerings. The idea of the critical museum also implied questioning the 'national' dimension of the NMW as a remnant of 19th-century nationalism which has its own particular meanings in a country that ceased to exist and in a city that was incorporated into the Russian Empire. Such obsolete ideas were radically replaced by real and vital problems of contemporary society, like LGBTQ+ community rights. The exhibition Ars Homo Erotica, opened in June 2010, was the first broad presentation of the traditions and problems of homoerotic art in Poland. ${ }^{18}$ And this was the only component of 
the ambitious and ground-breaking program that was executed, as several months later Piotr Piotrowski was forced to resign.

This example shows the (personal and professional) risk-taking that can be necessary to - try to - create institutional change. And how difficult it can be for institutions, particularly for their Boards of Trustees or leadership, to accept 'radical' change. It may be one thing in theory to agree to a new plan of reform, and then a whole different matter to accept in practice the necessary changes. All the more so if these changes include the replacement of higher-up staff and the need for management to essentially replace themselves. As this example illustrates, embracing vulnerability is one of the most challenging aspects of practicing decoloniality that requires extraordinary commitment to fully follow through.

\section{Voices from the Colonies | National Museum of Denmark | Copenhagen, Denmark}

The permanent exhibition titled Voices from the Colonies opened on 13 October 2017 in the National Museum of Denmark and is one of the first significant museum projects in the country about the colonial era and shares little-known information about this past. It is the result of long-running research and curatorial activities of the museum's team which previously led to the creation of the temporary exhibition The Danish West Indies Building the Colony (2011) as well as a website that presents the outcomes of the project. ${ }^{19}$ The core idea of that earlier exhibition was to reveal the structures, functions, and people of the colony. The newer permanent exhibition, however, is organized around a different idea: giving voice to the real historical people whose lives were determined or marked by colonialism. It concerns Denmark's colonial history in the Caribbean, India, West Africa, and Greenland from the perspective of individual biographies, the true-life paths of people who once lived in colonial realities. Their personal experiences are the main focus, even though this is a risky and difficult strategy for reasons detailed by Gayatri Chakravorty Spivak in her famous essay, "Can the Subaltern Speak?"20

The exhibition is built up of dramatic stories of loss, fear, and violence. It touches the most extreme experiences, including enslavement, childhood trauma, broken families, and rape. But it does not present stigmatization or a one-sided vision of biographies, as it also highlights positive values and 
experiences like hope, power, and the fight for freedom. For example, the history of the colonial abuse and rape of an enslaved woman called Anna Catherina concludes with her seeking and receiving justice. But a happy end' is not the standard assumption and the exhibited examples were not selected in order to present an overly optimistic version of colonial histories. Instead, the main goal of the exhibition is to have visitors reflect on how colonialism in different ways has influenced the lives of people living under colonial regimes. Their strategy of putting names and faces onto history helps to create a sense of proximity to the protagonists. ${ }^{21}$ This enables compassion and empathy, if visitors are open to the histories and allow themselves to be affected by them on a deeper, personal level. This vulnerable experience of being touched or even wounded by the pain of historical others is crucial for a fundamental change in perception: colonial pasts are not closed and fixed, but continue to influence the lives of people across the globe.

The strength of the exhibition lies in avoiding a strict dichotomy between colonizers and those who were colonized. There are no distinctions between objects from the 'Danish' and the 'ethnographic' collections, successfully countering the idea that ethnographic objects are in the museum to represent the 'other.'22 This is further reinforced by presenting narrations of stories in the exhibition from multiple perspectives and argumentations. This is by no means to deny colonial injustices, violence, and pain, but to also illustrate how the colonial system inevitably ultimately harms both sides, not only those who were forced to sacrifice their lives producing coveted goods, but sooner or later also those who benefited from the profits. Such an approach enables vulnerable experiences and directs the visitors to reflect on current problems and debates about racism, as well as existent inequalities in all possible areas, including the economy, healthcare, and education.

\section{Further reading}

From Museum Critique to Critical Museum | edited by Katarzyna MurawskaMuthesius and Piotr Piotrowski | 2017

Looking Back Ahead: A Short History of Collaborative Work with Indigenous Source Communities at the Weltmuseum Wien | Claudia Augustat and Wolfgang Kapfhammer $\mid 2017$ A Theory of Taking $\mid$ Dan Hicks $\mid 2020$ 


\section{Further examples}

Getting In exhibition at the Immigration Museum

Melbourne, Australia (2003-2015)

"More than 9 million people have migrated to Australia since 1788. Countless others have tried and failed. Since the 1800 s, various immigration policies have dictated who gets in. This exhibition shows how and why our immigration policies have changed. You'll see photographs, historical objects, and personal stories that show the effects of these policies on cultural diversity in Victoria. Central to the exhibition is an interactive theatre experience whereby visitors find themselves in the role of a government official charged with the responsibility of interviewing people applying to migrate to Australia, and discovering whether or not they 'get in'." 23

JASMIM traditional Ukrainian music group at the Museu do Traje

São Brás de Alportel, Portugal (since 2014)

“The vocal group 'JASMIN' was formed at the Museum of Sao Bras de Alportel, on the eve of Christmas in late 2014. We are all citizens of Ukraine, which we are proud of. But we chose São Brás de Alportel, a small place in Portugal, to live and work. We are very far from Ukraine, where we were born, but here in a foreign land we all strive to be happy. We formed our group to show our culture, our life, our traditions and the music we learned from childhood." ${ }^{24}$

With our thanks for this suggestion to Lorena Sancho Querol.

Biopolis artistic residency at the Botanic Gardens of the Jagiellonian University Krakow, Poland (2019)

"The intervention was a result of an art \& research residency during which the artist spent two weeks in the garden, accompanied by a research team, discovering the history of the institution, observing the way it functions, conducting interviews with its employees and discussing her observations during open meetings held in the garden. Grzywnowicz's intervention took a form of a contrafactual, alternative guided tour. It was the artist's response to the colonial structures of organising knowledge and exhibiting

23 As quoted from the Immigration Museum website. Available at https://museumsvictoria. com.au/immigrationmuseum/whats-on/getting-in/ (accessed 1 April 2021).

24 As quoted from the Museu do Traje website (in Ukrainian, machine-translated through Google). Available at https://www.museu-sbras.com/jasmim.html (accessed 1 April 2021). 
nature that she observed in the garden. The two crucial notions for this tour were, on one hand, the clear divisions between 'native' and 'exotic' (and value that is attributed to each of the categories); on the other hand - the peripheries, both of the topography of the garden itself, but also as a position from which the discourse of the institution is being constructed and reproduced, in relationship to the 'center': former colonial empires and botanical institutions that resulted from their colonial explorations." ${ }^{25}$ With our thanks for this suggestion to Aleksandra Janus.

\section{In Our Backyard exhibition at the Gallery Gachet}

Vancouver, Canada (2011)

"In Our Backyard is a photo storytelling series and art exhibition [...] While Canada has yet to obtain accurate statistics on the actual number of homeless, the nation wide population is estimated to be close to 300,000 , with an estimated population of 150,000 street-involved youth on any given day in this country. In Our Backyard showcases photos taken and art work created by seven youth participants, each member part of a team who identify themselves as the GVSS Youth Action Squad (YAS) - and have all experienced homelessness within the Greater Vancouver region. As part of the Homeless Voices/Call to Action Project 2011, the YAS which the youth have been involved in for the past 5 months has served as a foundation for these young people to find a voice in their community by sharing their stories and solutions to ending youth homelessness throughout the region. ${ }^{26}$

\section{STIRRING exhibition at the Asia and Pacific Museum}

Warsaw, Poland (2020-2021)

"The exhibition, which completes a project run by the Asia and Pacific Museum in cooperation with the students of the Academy of Fine Arts in 2019, pairs museum objects with contemporary pieces. The students visited museum store rooms, participated in workshops and talked to curators. Each person chose one object which STIRRED their emotions (through its form, history, function, meaning) or which they wished to STIR back to life (return context and breathe life into museum objects

25 As quoted from the abstract of a presentation by Aleksandra Janus and Karolina Grzywnowicz, titled 'Native and Exotic: Towards Decolonizing a Botanical Garden' (presented during the conference Decolonizing Museum Cultures and Collections: Mapping Theory and Practice in East-Central Europe, Warsaw 2020).

26 As quoted from the Gallery Gachet website. Available at http://gachet.org/event/in-ourbackyard-youth-homelessness-photovoice-art-project-presents/ (accessed 1 April 2021). 
that were enclosed in cases and shelved away). The works created are the effects of these experiences. By juxtaposing museum objects with the works of young artists, we raise questions about the definitions and borders of art. [...] Through the juxtaposition of museum objects with the works of young artists, we confront the existing definitions and pre-conceptions about art. This juxtaposition and the authors' texts give an insight into the creative process, and inform the reception of the work and its interpretation." ${ }^{27}$

With our thanks for this suggestion to Barbara Banasik.

\section{References}

Augustat, Claudia, and Kapfhammer, Wolfgang. 2017. "Looking Back Ahead: A Short History of Collaborative Work with Indigenous Source Communities at the Weltmuseum Wien." Boletim Museu Paraense Emílio Goeldi: Ciências Humanas 12.3: 749-764.

Chakrabarty, Dipesh. 2000. Provincializing Europe: Postcolonial Thought and Historical Difference. Princeton and Oxford: Princeton University Press.

Gilson, Errin C. 2013. The Ethics of Vulnerability: A Feminist Analysis of Social Life and Practice. London and New York: Routledge.

Hicks, Dan. 2020. "A Theory of Taking." In Dan Hicks, The Brutish Museums: The Benin Bronzes, Colonial Violence and Cultural Restitution. London: Pluto Press. 18-24.

Kassim, Sumaya. 2017. “The Museum Will Not Be Decolonised." Media Diversified [essay], 15 November 2017. Available at https://mediadiversified.org/2017/11/15/ the-museum-will-not-be-decolonised/ (accessed 1 April 2021).

Katz, Meighen. 2019. Narratives of Vulnerability in Museums: American Interpretations of the Great Depression. London and New York: Routledge.

Leszkowicz, Paweł. 2010. Ars Homo Erotica. Warsaw: CePed.

Lidchi, Henrietta. [1997] 2010. "The Poetics and the Politics of Exhibiting Other Cultures." In Stuart Hall, ed. Representation: Cultural Representations and Signifying Practices. London; Thousand Oaks, CA; and New Delhi: Sage Publications. 151-222.

McLoughlin, Moira. 2014. Museums and the Representation of Native Canadians: Negotiating the Borders of Culture. London and New York: Routledge.

27 As quoted from the Asia and Pacific Museum website. Available at https://www.muzeumazji. $\mathrm{pl} / \mathrm{en} /$ temporary-exhibition/poruszenie/ (accessed 1 April 2021). 
Murawska-Muthesius, Katarzyna, and Piotrowski, Piotr, eds. 2017. From Museum Critique to Critical Museum. London and New York: Routledge.

Piotrowski, Piotr. 2011. Muzeum krytyczne [Critical Museum]. Poznań: Dom Wydawniczy Rebis.

Sandell, Richard, and Nightingale, Eithne, eds. 2012. Museums, Equality and Social Justice. London and New York: Routledge.

Sarr, Felwine, and Savoy, Bénédicte. 2018. The Restitution of African Cultural Heritage: Toward a New Relational Ethics. Paris: Ministère de la Culture.

Sebro, Louise. 2018. "Voices from the Colonies." Presented during the Annual Conference of the Research Center for Material Culture 'Reckoning with History: Colonial Pasts, Museum Futures, and Doing Justice in the Present.' YouTube [video lecture], 19 September 2018. Available at https:/www.youtube.com/ watch?v=sizuOz5wYGI (accessed 1 April 2021).

Simon, Nina. 2010. The Participatory Museum. Santa Cruz: Museum 2.o.

Spivak, Gayatri Chakravorty. 1985. "Can the Subaltern Speak?: Speculations on Widow-Sacrifice." Wedge 7/8: 120-130.

Tinning, Katrine. 2017. The Ambivalent Potentiality of Vulnerability: Museum Pedagogy in Exhibitions on Difficult Matters and its Ethical Implications. Lund: Lund University.

Tinning, Katrine. 2018. "Vulnerability as a Key Concept in Museum Pedagogy on Difficult Matters." Studies in Philosophy and Education 37.2: 147-165.

Valley, Geer. 2019. "Decolonization Can't Just Be a Metaphor." Africa Is A Country [article], 11 December 2019. Available at https:/africasacountry.com/2019/11/ decolonization-cant-just-be-a-metaphor (accessed 1 April 2021).

Viso, Olga. 2017. "Learning in Public: An Open Letter on Sam Durant's Scaffold." Walker Art Center [letter], 26 May 2017. Available at https://walkerart.org/ magazine/learning-in-public-an-open-letter-on-sam-durants-scaffold (accessed 1 April 2021).

Viso, Olga. 2018. "Decolonizing the Art Museum: The Next Wave." The New York Times [opinion], 1 May 2018. Available at https://www.nytimes.com/2018/05/01/ opinion/decolonizing-art-museums.html (accessed 1 April 2021). 


\section{Concluding Remarks}

Practicing decoloniality is happening all around us, in all kinds of museums, whether we consider them to be overtly colonial or not. As this book has shown, the examples abound from all over the world, both in large urban institutions as well as in rural areas or individually owned museums. We hope the examples will be inspiring, particularly to those museum staff who did not previously consider decoloniality to be relevant to their institutions. Additionally, for museum visitors, we hope that this book will provide a new perspective and will reveal how even museum visiting can be an act of decoloniality. We encourage you to reflect critically during your visits and to provoke museums with your questions. Only then can the decolonization of museums and society go hand in hand.

Finally, while we highlight the urgency of practicing decoloniality in museums, we also agree with Ariella Aïsha Azoulay that "it is not possible to decolonize the museum without decolonizing the world." ${ }^{\text {O Our conceptual }}$ framework with six aims of decolonization is presented here with examples from museums. Yet the terms we use - such as transparency, empathy, visibility - can be applied far more universally, for instance to politics, education, or social interactions. The actions embedded in each of the six terms are all important in creating a more just society. Nevertheless, practicing decoloniality in the museum remains an important part of decolonizing the world. This work of decolonization is an urgent task for all of us to do together. It may seem daunting, but with plenty of examples to follow, the road ahead should become a little bit more accessible.

\section{References}

Alli, Sabrina. 2020. "Ariella Aïsha Azoulay: 'It Is Not Possible to Decolonize the Museum without Decolonizing the World." Guernica [interview], 12 March 2020. Available at https://www.guernicamag.com/miscellaneous-files-ariella-aishaazoulay/ (accessed 1 April 2021).

$1 \quad$ Alli 2020.

Ariese, Csilla E., and Magdalena Wróblewska, Practicing Decoloniality in Museums: A Guide with Global Examples. Amsterdam, Amsterdam University Press 2022 DOI: 10.5117/9789463726962_CONCL 


\section{Contributors}

The authors wish to thank the following contributors for suggesting examples of decolonial practices and bringing fantastic museums, programs, exhibitions, projects, literature, and methodologies to our attention:

Daria Agapova

Barbara Banasik

Mariana Françozo

Aleksandra Janus

Britta Timm Knudsen

Daniëlle Kuijten

Erica Lehrer

Wayne Modest

Katarzyna Murawska-Muthesius

Laura Pozzi

Lorena Sancho Querol

Anna Szöke

Joanna Wawrzyniak 


\section{Acknowledgements}

This work forms part of the ECHOES project which has received funding from the European Union's Horizon 2020 research and innovation program under grant agreement No. 770248. The research took place as part of Work Package 3 'City Museums and Multiple Colonial Pasts,' designed and led by Dr. Joanna Wawrzyniak.

We are particularly grateful to our colleagues within ECHOES's Work Package 3 for supporting the creation of this book: Łukasz Bukowiecki, Laura Pozzi, and Joanna Wawrzyniak. We are furthermore grateful to the insightful participants of the conference Decolonizing Museum Cultures and Collections: Mapping Theory and Practice in East-Central Europe (Warsaw, October 2020) whose suggestions and feedback on a first draft of this book were most helpful. Finally, we are grateful to the Amsterdam Museum and the Museum of Warsaw for their early support of the creation of this book. 


\section{Author Biographies}

CsIlla E. ARIESE is a museologist specialized in community engagement and practicing decoloniality. She worked as a postdoctoral researcher to study how the Amsterdam Museum is dealing with its colonial past. Prior to this she completed her $\mathrm{PhD}$, titled The Social Museum in the Caribbean: Grassroots Heritage Initiatives and Community Engagement (2018).

MAGDALENA WRóBLEWSKA is an art historian specializing in museology. She is a research fellow in the projects Connecting Art Histories and the Museum (Kunsthistorisches Institut in Florenz- MPI and Staatlichen Museen zu Berlin, 2012-2014) and European Colonial Heritage Modalities in Entangled Cities (Horizon 2020, 2018-2021). As head of research at the Museum of Warsaw (2015-2021) she co-curated its core exhibition and co-authored the accompanying publication Things of Warsaw (2017). 


\section{References}

Alli, Sabrina. 2020. "Ariella Aïsha Azoulay: 'It Is Not Possible to Decolonize the Museum without Decolonizing the World." Guernica [interview], 12 March 2020. Available at https://www.guernicamag.com/miscellaneous-files-ariella-aishaazoulay/ (accessed 1 April 2021).

Anderson, Wes. 2018. "Introduction." In Wes Anderson and Juman Malouf, authors; Sabine Haag and Jasper Sharp, eds. Spitzmaus Mummy in a Coffin and Other Treasures. Köln: Verlag der Buchhandlung Walther König. 18-19.

Ariese, Csilla E. 2019a. Decolonizing the Amsterdam Museum: A Work-in-Progress to Becoming a More Inclusive City Museum. ECHOES: European Colonial Heritage Modalities in Entangled Cities [Online]. Available at http://projectechoes.eu/ deliverables/ (accessed 1 April 2021).

Ariese, Csilla E. 2019b. The Social Museum in the Caribbean: Grassroots Heritage Initiatives and Community Engagement - Appendix: Caribbean Museums Database. Leiden: Leiden University Repository.

Ariese, Csilla E., and Françozo, Mariana. 2019. "Completeness: How the Lack of a Mouse in a Box Revisits the Spectacle of the Kunstkammer." Curator 62.4: 649-656. DOI: doi.org/10.1111/cura.12317.

Ariese-Vandemeulebroucke, Csilla E. 2018. The Social Museum in the Caribbean: Grassroots Heritage Initiatives and Community Engagement. Leiden: Sidestone Press.

Augustat, Claudia, and Kapfhammer, Wolfgang. 2017. "Looking Back Ahead: A Short History of Collaborative Work with Indigenous Source Communities at the Weltmuseum Wien." Boletim Museu Paraense Emílio Goeldi: Ciências Humanas 12.3: 749-764.

Azoulay, Ariella Aïsha. 2019. Potential History: Unlearning Imperialism. London: Verso.

Bennett, Tony. 1995. The Birth of the Museum: History, Theory, Practice. London: Routledge.

Bourdieu, Pierre. 1993. The Field of Cultural Production: Essays on Art and Literature. New York: Columbian University Press.

Bouquet, Mary, ed. 2012. Museums: A Visual Anthropology. London: Bloomsbury. Búron Díaz, Manuel. 2012. "Los Museos Comunitarios Mexicanos en el Proceso de Renovación Museológica." Revista de Indias 72.254: 177-212.

Castro, Fernanda; Magalhães, Aline Montenegro; Sancho Querol, Lorena; Severo, Rosário; and Botas, Ana. Forthcoming. "Decolonial Educational Practices at National Museums in Rio de Janeiro and Lisbon: Towards a Comparative Study." Revista de Estudos Ibero-Americanos. 
Catlin-Legutko, Cinnamon. 2016. "We Must Decolonize Our Museums | TEDxDirigo." YouTube [video lecture], 6 December 2016. Available at https://www.youtube. com/watch?v=jyZAgG8--Xg (accessed 1 April 2021).

Chakrabarty, Dipesh. 200o. Provincializing Europe: Postcolonial Thought and Historical Difference. Princeton and Oxford: Princeton University Press.

Childs, Adrienne L. 2019. "Exhibition Review of 'Le Modèle Noir de Géricault à Matisse.” Nineteenth-Century Art Worldwide 18.2. DOI: doi.org/10.29411/ ncaw.2019.18.2.18.

Chipangura, Njabulo. 2020. "Co-curation and New Museology in Reorganizing the Beit Gallery at the Mutare Museum, Eastern Zimbabwe." Curator 63.3: 431-446. DOI: doi.org/10.1111/cura.12375.

Chipangura, Njabulo, and Chiripanhura, Pauline. 2017. "Reconfiguring the Jindwi Traditional Drums in a Post-colonial Mutare Museum Setting." In Nhemachena Artwell, Jairos Kangira, and Nelson Mlambo, eds. Decolonisation of Materialities or Materialisation of (Re-) Colonisation? Symbolism, Languages, Ecocritism and (Non) Representationalism in 21st Century Africa. Bamenda: Langaa RPCIG. 219-240.

Chipangura, Njabulo, and Mataga, Jesmael. 2021. Museums as Agents for Social Change: Collaborative Programmes at the Mutare Museum. London: Routledge. Clifford, James. 1997. Routes: Travel and Translation in the Late Twentieth Century. Cambridge, MA: Harvard University Press.

Cooper, Karen Coody. 2008. Spirited Encounters: American Indians Protest Museum Policies and Practices. Lanham, MD; New York; Toronto; and Plymouth: Altamira Press.

Cooper, Karen Coody, and Sandoval, Nicolasa I. 2006. Living Homes for Cultural Expression: North American Native Perspectives on Creating Community Museums. Washington, D.C. and New York: Smithsonian Institution and National Museum of the American Indian.

Decolonize This Place. 2018. "Open Letter to the Brooklyn Museum: Your Curatorial Crisis Is an Opportunity to Decolonize.” Decolonize Brooklyn Museum [letter], 3 April 2018. Available at https://decolonizebrooklynmuseum.wordpress. com/2018/04/03/the-journey-begins/ (accessed 1 April 2021).

de Varine, Hugues. 1978. "L’Écomusée." Gazette 11.2: 28-40.

Edwards, Elizabeth. 2018. "Addressing Colonial Narratives in Museums." The British Academy [blog], 19 April 2018. Available at https://www.thebritishacademy. ac.uk/blog/addressing-colonial-narratives-museums/ (accessed 1 April 2021).

Felipe Beltrão, Jimena, ed. 2017. “Dossiê 'Patrimônio Indígena e Coleções Etnográficas.” Boletim Museu Paraense Emílio Goeldi: Ciências Humanas 12.3: 709-789. Findlen, Paula. 1989. "The Museum: Its Classical Etymology and Renaissance Genealogy." Journal of the History of Collections 1.1: 59-78. 
Fouseki, Kalliopi. 2010. “'Community Voices, Curatorial Choices': Community Consultation for the 1807 Exhibitions." Museum and Society 8.3: 180-192.

Fouseki, Kalliopi, and Smith, Laurajane. 2013. "Community Consultation in the Museum: The 2007 Bicentenary of Britain's Abolition of the Slave Trade.” In Viv Golding and Wayne Modest, eds. Museums and Communities: Curators, Collections and Collaboration. London and New York: Bloomsbury. 232-245.

Fuller, Nancy J. 1992. "The Museum as a Vehicle for Community Empowerment: The Ak-Chin Indian Community Ecomuseum Project." In Ivan Karp, Christine Mullen Kreamer, and Steven D. Lavine, eds. Museums and Communities: The Politics of Public Culture. Washington: Smithsonian Institution. 327-365.

Gilson, Errin C. 2013. The Ethics of Vulnerability: A Feminist Analysis of Social Life and Practice. London and New York: Routledge.

Hicks, Dan. 2020. "A Theory of Taking." In Dan Hicks, The Brutish Museums: The Benin Bronzes, Colonial Violence and Cultural Restitution. London: Pluto Press. 18-24.

Hoff, Kenny. 2015. “1/6 GLOW: A Festival of Fire \& Light Santa Cruz 10/16/2015." YouTube [video], 21 October 2015. Available at https://www.youtube.com/ watch?v=ZoSq71FCRiQ (accessed 1 April 2021).

ICOM. 2017. ICOM Code of Ethics for Museums. Paris: International Council of Museums.

Karp, Ivan, and Kratz, Corinne A. 2015. "The Interrogative Museum." In Raymond A. Silverman, ed. Museum as Process: Translating Local and Global Knowledges. London and New York: Routledge. 279-298.

Kassim, Sumaya. 2017. “The Museum Will Not Be Decolonised." Media Diversified [essay], ${ }_{5}$ November 2017. Available at https://mediadiversified.org/2017/11/15/ the-museum-will-not-be-decolonised/ (accessed 1 April 2021).

Katz, Brigit. 2018. "Sprawling Museum of Black Civilizations Opens in Senegal." Smithsonian Magazine [exhibition review], 10 December 2018. Available at https://www.smithsonianmag.com/smart-news/sprawling-museum-blackcivilizations-opens-senegal-180970976/ (accessed 1 April 2021).

Katz, Meighen. 2019. Narratives of Vulnerability in Museums: American Interpretations of the Great Depression. London and New York: Routledge.

Keyes, Allison. 2017. "In This Quiet Space for Contemplation, a Fountain Rains Down Calming Waters." Smithsonian Magazine [exhibition review], 21 September 2017. Available at https://www.smithsonianmag.com/smithsonian-institution/ quiet-space-contemplation-fountain-rains-down-calming-waters-180964981/ (accessed 1 April 2021).

Kimeria, Ciku. 2019. "Dakar's Museum of Black Civilizations Is a Vital Step for a People Reclaiming their History." QuartzAfrica [exhibition review], 
25 January 2019. Available at https://qz.com/africa/1533523/dakars-museumof-black-civilizations-tells-africas-story/ (accessed 1 April 2021).

Kreps, Christina. 2011. "Non-Western Models of Museums and Curation in Crosscultural Perspective." In Sharon Macdonald, ed. A Companion to Museum Studies. Malden and Oxford: Wiley-Blackwell. 457-472.

Leszkowicz, Paweł. 2010. Ars Homo Erotica. Warsaw: CePed.

Lidchi, Henrietta. [1997] 2010. "The Poetics and the Politics of Exhibiting Other Cultures." In Stuart Hall, ed. Representation: Cultural Representations and Signifying Practices. London; Thousand Oaks, CA; and New Delhi: Sage Publications. 151-222.

Lonetree, Amy. 2012. Decolonizing Museums: Representing Native America in National and Tribal Museums. Chapel Hill: The University of North Carolina Press.

Lorde, Audre. 1984. Sister Outsider: Essays and Speeches by Audre Lorde. Berkeley: The Crossing Press.

Macron, Emmanuel. 2017. "Aujourd'hui nous sommes orphelins d'un imaginaire commun: le patrimoine africain ne peut pas être prisonnier de musées européens." Twitter [post], 28 November 2017. Available at https://twitter.com/ EmmanuelMacron/status/935488489663156226?s=2o (accessed 1 April 2021).

Mawere, Munyaradzi, and Tevera, Genius. 2015. "Zimbabwean Museums in the Digital Age: A Quest to Increase Museum Visibility in Public Space through Social Media." In Munyaradzi Mawere, Henry Chiwaura, and Thomas Panganayi Thondhlana, eds. African Museums in the Making: Reflections on the Politics of Material and Public Culture in Zimbabwe. Bamenda: Langaa RPCIG. 247-268.

McLoughlin, Moira. 2014. Museums and the Representation of Native Canadians: Negotiating the Borders of Culture. London and New York: Routledge.

Modest, Wayne, and Lelijveld, Robin, eds. 2018. Words Matter: An Unfinished Guide to Word Choices in the Cultural Sector. Work in Progress series. Wormerveer: Tropenmuseum, Afrika Museum, Museum Volkenkunde and Wereldmuseum. Modest, Wayne; Lelijveld, Robin; and Rijnks-Kleikamp, Ninja. 2020. Re-collecting and Re-allocation: Collection Assessment, Ethical Deaccessioning and Multiple Stakeholders. Work in Progress series. Amersfoort: Tropenmuseum, Afrika Museum, Museum Volkenkunde and Wereldmuseum.

Moshenska, Gabriel. 2020. "Creating a Museum of British Colonialism." New African [article], 16 September 2020. Available at https://newafricanmagazine.com/24035/ (accessed 1 April 2021).

Murawska-Muthesius, Katarzyna, and Piotrowski, Piotr, eds. 2017. From Museum Critique to Critical Museum. London and New York: Routledge.

Ngũgĩ wa Thiong'o. [1986] 2004. Decolonising the Mind: The Politics of Language in African Literature. Nairobi: East African Educational Publishers. 
Norris, Linda, and Tisdale, Rainey. 2017. "Nuts and Bolts: Developing a Toolkit for Emotion in Museums." Exhibition 2017 (Spring): 100-108.

Oelze, Sabine. 2019. "How a Cologne Museum Is Dealing with its Colonial Heritage." $D W$ [article], 10 January 2019. Available at https://p.dw.com/p/3QUcG (accessed 1 April 2021).

Opoku, Kwame. 2019. “Appeal To Open German Museums' Inventories On African Objects." Modern Ghana [feature], 15 October 2019. Available at https://www. modernghana.com/news/961408/appeal-to-open-german-museums-inventorieson-afri.html (accessed 1 April 2021).

Owuor, Yvonne Adhiambo. 2020. "Derelict Shards: The Roaming of Colonial Phantoms." CODESRIA Bulletin Online 10: 1-10. Available at https://codesria.org/IMG/ pdf/10-_y_owuor_codbul_online_1_.pdf (accessed 1 April 2021).

Piotrowski, Piotr. 2011. Muzeum krytyczne [Critical Museum]. Poznań: Dom Wydawniczy Rebis.

Pomian, Krzysztof. 1994. "The Collection: Between the Visible and the Invisible." In Susan M. Pearce, ed. Interpreting Objects and Collections. London and New York: Routledge. 160-174.

Pozzi, Laura. Forthcoming. "China, the Maritime Silk Road, and the Memory of Colonialism in the Asia Region." In Simon Lewis, Jeffrey K. Olick, Małgorzata Pakier, and Joanna Wawrzyniak, eds. Regions of Memory: Transnational Formations. London: Palgrave.

Prakash, Gyan. 1992. "Science 'Gone Native' in Colonial India.” Representations 40: $153-178$.

Procter, Alice. 2019. "UK Museums Should Be Honest about Being Stuffed with Stolen Goods." The Guardian [opinion], 20 February 2019. Available at https:// www.theguardian.com/commentisfree/2019/feb/20/uk-museums-honest-stolengoods-imperialism-theft-repatriation (accessed 1 April 2021).

Riva, Raffaella, ed. 2017. Ecomuseums and Cultural Landscapes: State of the Art and Future Prospects. Santarcangelo di Romagna: Maggioli Editore.

Ronan, Kristine. 2014. "Native Empowerment, the New Museology, and the National Museum of the American Indian." Museum \& Society 12.1: 132-147.

Said, Edward W. [1978] 2003. Orientalism. London: Penguin Group.

Sandell, Richard, and Nightingale, Eithne, eds. 2012. Museums, Equality and Social Justice. London and New York: Routledge.

Santa Cruz MAH. 2013. "GLOW: A Festival of Fire and Light 2013." Vimeo [video], 23 November 2013. Available at https://vimeo.com/80158912 (accessed 1 April 2021). Sarr, Felwine, and Savoy, Bénédicte. 2018. The Restitution of African Cultural Heritage: Toward a New Relational Ethics. Paris: Ministère de la Culture.

Searcey, Dionne, and Nayeri, Farah. 2019. "Senegal's Museum of Black Civilizations Welcomes Some Treasures Home." The New York Times [exhibition review], 
15 January 2019. Available at https://www.nytimes.com/2019/01/15/arts/design/ museum-of-black-civilizations-restitution-senegal-macron.html (accessed 1 April 2021).

Sebro, Louise. 2018. "Voices from the Colonies." Presented during the Annual Conference of the Research Center for Material Culture 'Reckoning with History: Colonial Pasts, Museum Futures, and Doing Justice in the Present.' YouTube [video lecture], 19 September 2018. Available at https://www.youtube.com/ watch?v=si3uOz5wYGI (accessed 1 April 2021).

Simon, Nina. 2010. The Participatory Museum. Santa Cruz: Museum 2.o.

Simon, Nina. 2013. "Quick Hit: Long Story about the MAH." Museum 2.o [blog], 20 March 2013. Available at http://museumtwo.blogspot.com/2013/o3/quickhit-long-story-about-mah.html (accessed 1 April 2021).

Simon, Nina. 2016. The Art of Relevance. Santa Cruz: Museum 2.o.

Smith, Claire. 2005. "Decolonizing the Museum: The National Museum of the American Indian in Washington, D.C." Antiquity 79-304: 424-439.

Spivak, Gayatri Chakravorty. 1985. "Can the Subaltern Speak?: Speculations on Widow-Sacrifice." Wedge 7/8: 120-130.

Stoler, Ann Laura. 2016. Duress: Imperial Durabilities in Our Times. Durham, NC: Duke University Press.

Stooke, Andrew. 2019. "Captain Cook Reimagined from the British Museum's Point of View." Third Text Online 1-12. Available at www.thirdtext.org/stooke-cookbritishmuseum (accessed 16 July 2021).

Stoudmann, Elisabeth. 2020. "Hamady Bocoum: 'Nous sommes tous des Africains'." Le Temps [interview], 27 March 2020. Available at https://www.letemps.ch/ culture/hamady-bocoum-sommes-africains (accessed 1 April 2021).

Tinning, Katrine. 2017. The Ambivalent Potentiality of Vulnerability: Museum Pedagogy in Exhibitions on Difficult Matters and its Ethical Implications. Lund: Lund University.

Tinning, Katrine. 2018. "Vulnerability as a Key Concept in Museum Pedagogy on Difficult Matters." Studies in Philosophy and Education 37.2: 147-165.

Turner Strong, Pauline. 1997. "Exclusive Labels: Indexing the National 'We' in Commemorative and Oppositional Exhibitions." Museum Anthropology 21.1: 42-56. Valley, Geer. 2019. "Decolonization Can't Just Be a Metaphor." Africa Is A Country [article], 11 December 2019. Available at https://africasacountry.com/2019/11/ decolonization-cant-just-be-a-metaphor (accessed 1 April 2021).

Van Huis, Iris. 2019. "Contesting Cultural Heritage: Decolonizing the Tropenmuseum as an Intervention in the Dutch/European Memory Complex." In Tuuli Lähdesmäki, Luisa Passerini, Sigrid Kaasik-Krogerus, and Iris van Huis, eds. Dissonant Heritages and Memories in Contemporary Europe. Cham: Palgrave Macmillan. 215-248. 
Viso, Olga. 2017. "Learning in Public: An Open Letter on Sam Durant's Scaffold." Walker Art Center [letter], 26 May 2017. Available at https://walkerart.org/ magazine/learning-in-public-an-open-letter-on-sam-durants-scaffold (accessed 1 April 2021).

Viso, Olga. 2018. "Decolonizing the Art Museum: The Next Wave." The New York Times [opinion], 1 May 2018. Available at https://www.nytimes.com/2018/05/o1/ opinion/decolonizing-art-museums.html (accessed 1 April 2021).

Wiginton, Christina, and Holman Conwill, Kinshasha. 2016. The National Museum of African American History \& Culture: A Souvenir Book. Washington, D.C.: Smithsonian Books.

Williams, Paul. 2007. Memorial Museums: The Global Rush to Commemorate Atrocities. Oxford and New York: Berg.

Williams, Tammy Ronique. 2012. "Tourism as a Neo-colonial Phenomenon: Examining the Works of Pattullo \& Mullings." Caribbean Quilt 2: 191-200.

Were, Anzetse. 2018. "Debt Trap? Chinese Loans and Africa's Development Options." South African Institute of International Affairs 66: 1-12. 



\section{Index}

activism, museum $\quad 26-28,82,84,88-89,98$

Amsterdam Museum, Amsterdam, Netherlands $16,40-42$

Art Workers Coalition 84

Azoulay, Ariella Aïsha 113

Belmont Estate $\quad$ 29-32

Black Emergency Cultural Coalition 84 Birmingham Museum \& Art Gallery,

Birmingham, UK $\quad 86-88$

Chipangura, Najbulo 28-29

Chiripanhura, Puline 29

civilizing $11-12,22,38$

colonialism 11-13, 26-27, 82, 88-89, 107-108

Cooper, Karen Coody $\quad 60-61$

decentering $15,40,51^{-} 54,5^{8}$

decoloniality $11-14,16-18,31,88,99,107,113$

decolonization $11-12,14-15,28,72-73,113$

decolonization, aims of $14-15,17,113$

Decolonize the Museum 12, 23, 26-27

Decolonize This Place 83

denormalization $15,51,105$

diversity $15,33,43,69-70,82-83,88,109$

Durant, Sam 102-104

ecomuseum 12, 48, 61-62, 72

Edwards, Elizabeth 11

empathy $15,67-71,74-75,90,98,108,113$

engagement, community $28-29,39-40,42-44$,

$48-49,68,72-74,94,98,102-104$

Fouseki, Kalliopi $\quad 40$

globalization $12-13,15,33,67-68,91-92$

Goethe-Institut Kenya, Nairobi, Kenya 84

inclusivity $15,37-40,42,47,88,97-98$

indigenous $22,52,60-63,94-95$

International Inventories Program $\quad 84-85$

International Slavery Museum, Liverpool,

UK 12, 23-26

Kassim, Sumaya $\quad 86-88,99$

Liberty Hall, Kingston, Jamaica $\quad 46-48$

Lorde, Audre 88

Memento Park, Budapest, Hungary $\quad 54-56$

Moshenska, Gabriel 89-9o

movements, museum $12-13,23,61,82-84$

Musee des Civilisations Noires, Dakar,

Senegal 90-92

Museo Tula, Lagun, Curaçao $\quad 72-74$

museology, new 49, 61, 104-105

museum, colonial $12,15,22,26$

Museum Detox 12, 82-83
Museum of British Colonialism 88-9o

Museum of London, London, UK 44-46

Museum-like Centers, Canada \& USA $\quad 60-62$

Mushaandja, Nashilongweshipwe 100

Mutare Museum, Mutare, Zimbabwe 23 , 28-29

National Museum Nairobi, Nairobi, Kenya 84

National Museum in Warsaw 104-107

National Museum of African American History and Culture, Washington, D.C., USA $\quad 7^{-0} 72$

National Museum of Denmark, Copenhagen, Denmark 107-108

National Museum of Modern Art, Kyoto, Japan $\quad 5^{6-58}$

Opoku, Kwame 86

Pan-Africanism 47, 90-92

Pitt Rivers Museum, Oxford, UK $\quad 32,83$, 100-102

Pitt Rivers, Augustus 101-102

Piotrowski, Piotr 104-107

POLIN Museum of the History of Polish Jews,

Warsaw, Poland $74-76$

practice, decolonial $14-15,17-18$

practice, participatory $29,39-40,42-43,61$, $79,100,110$

Procter, Alice 82

representation $21,23,26-27,38,40-41,52,61$, $67,69,90,93,108$

restitution $79,81-82,90-92$

repatration $12,61-62,83$

Sarr \& Savoy (Felwine Sarr and Bénédicte Savoy) $82,84,101$

Santa Cruz Museum for Art \& History (MAH) 42-44

Simon, Nina 43

Tate Modern. London, UK $\quad 76-77$

theory, post-colonial $12,16,73$

Thompson, Christian 100-102

transparency $\quad 15,81-84,86,89-90,113$

Tropenmuseum, Amsterdam, Netherlands 23, $26-28,78,83$

visibility $15,17,21-23$

Viso, Olga 98-99, 103

vulnerability $15,17,97-100$

Walker Art Center, Minneapolis, USA $\quad 84,98$, 102-104

Zeefuik, Simone 23 
